\author{
Universidade de São Paulo \\ Instituto de Física e Faculdade de Educação
}

\title{
O ideal do Belo como princípio, meio e fim do ensino-aprendizagem da Física.
}

\author{
Ivan Lúcio da Silva
}




\title{
O ideal do Belo como princípio, meio e fim do ensino-aprendizagem da Física.
}

\author{
Ivan Lúcio da Silva
}

Orientador: Prof. Dr. João Zanetic

Dissertação de mestrado apresentada ao Programa de Pós-Graduação Interunidades em Ensino de Ciências como requisito para a obtenção do título de Mestre em Ensino em Ciências - Modalidade Física

São Paulo 
FICHA CATALOGRÁFICA

Preparada pelo Serviço de Biblioteca e Informação do Instituto de Física da Universidade de São Paulo

Silva, Ivan Lúcio da

O ideal do Belo como princípio, meio e fim do ensinoaprendizagem da física. São Paulo, 2010.

Dissertação (Mestrado) - Universidade de São Paulo. Faculdade de Educação, Instituto de Física, Instituto de Química e Instituto de Biociências.

Orientador: Prof. Dr. João Zanetic

Área de Concentração: Ensino de Física

Unitermos: 1. Física - Estudo e ensino; 2. Construção do conhecimento; 3.Estética; 4. Formação do indivíduo; 5. Linguagem científica. 


\section{Agradecimento}

Por ter me conduzido pela mão e cultivado em mim o ardor pela tarefa do esclarecimento, posso hoje contemplar as paisagens do belo à procura de suas mais recônditas manifestações;

De seu ser é originário tudo o que de mais justo e fino floresce em mim;

Personificação de ternura, suavidade e compaixão, observo o seu olhar cálido a se voltar sempre para as aflições de quantos você já partilhou o caminho;

No seu exemplo contínuo, percebo que cada palavra e gesto são administrados em auxílio, a serviço do bem: muitos são os que neles encontraram refrigério para atrozes problemas humanos;

Com você sigo de mãos dadas. Sentindo a tepidez que delas se irradia, vou buscando aprender diariamente as lições mais preciosas e difíceis de esforço por um pouco mais de autodomínio e de aprimoramento da responsabilidade ética diante da existência;

A você, MINHA MÃE MUITO AMADA, que jamais soube viver senão com beleza, pela beleza e para a beleza é dirigido este singelo, porém sentido, reconhecimento.

I'm glad, dear! 


\section{Resumo}

Entre as pretensões deste trabalho, situa-se a construção de instrumentos interpretativos com base em confluências dos pensamentos de Nelson Goodman, John Dewey e Ludwig Wittgenstein no âmbito da epistemologia, a fim de ir ao encontro dos méritos destas filosofias para a liberação de modos valiosos de relacionamento com os saberes científicos. Tais modos, até aqui, têm sido majoritariamente negligenciados pela educação em ciências. O uso desses instrumentos permitirá compreender que - como um dos resultados mais característicos que se seguem da montagem da civilização atual - a legitimação pública do empreendimento científico se fez ao preço do estreitamento nos modos de ver a ciência, a ponto de impedir a apreciação do seu rico potencial de significados. A relação do homem comum com a ciência segue, hoje, obediente ao comando de demonstrações ruidosas da técnica, sob a fascinação de objetos e formas de vida que simbolizam seus êxitos de manipulação e reprodução. Alinhadas com esta tendência, as expectativas das sociedades modernas voltam-se mais e mais para uma instrução comprometida com a preparação de indivíduos funcionais, capazes de fazer aplicação objetiva e eficiente de procedimentos para o fim de materializar produtos e serviços com valor de mercadoria. Este processo marca o domínio simbólico com a construção de um particular sistema de símbolos que, ao se consolidar, remove os vestígios da experiência do sítio do conhecimento científico. Com o propósito de restaurar a continuidade entre ciência e experiência, deve-se lançar luz sobre as interações fecundas que os significados singulares efetivados no curso da prática da ciência mantêm com a estrutura sistemática abstrata que emerge como sua forma acabada. Para fechar esse hiato, aposta-se na articulação de uma concepção educacional aberta à apreciação estética dos artefatos simbólicos da ciência. A transição de uma leitura da física dominada por suas consequiências técnicas para outra que também captura seus modos de funcionamento estético é feita por intermédio da analogia que aqui se demonstra existir entre dois processos, a saber, aquele em que a visão estética de um artefato da física se estabelece nas mediações educativas e o percurso da apreciação das performances de uma obra musical. Desta analogia, irá se configurar uma imagem do ensino de física como arte de performance.

Palavras-chaves: Física - Estudo e ensino; Construção do conhecimento; Estética; Formação do indivíduo; Linguagem científica 


\section{Abstract}

Among the intents of this work lies the construction of interpretive instruments based on confluences of the thoughts of Nelson Goodman, John Dewey and Ludwig Wittgenstein in the domain of epistemology, in order to find the results these philosophies yield concerning the liberation of valuable modes of relationship with the lore of science. Such modes thus far have been mostly neglected by science education. Using these instruments allows seeing that - as one of the most characteristic aftermaths that follow from the mounting of current civilization - the public legitimacy of scientific enterprise has been consummated at the price of a squeezing in the ways of seeing science, to the point of blocking the appreciation of its wealth of potential meanings. Nowadays, the transactions of the ordinary person with science go obedient to the command of loud demonstrations of the technique, under the fascination of objects and ways of life that symbolize its successes in manipulation and reproduction. Aligned with this trend, the expectations of modern societies turn more and more to an instruction committed to preparing functional individuals, so as to enable them to carry out objective and efficient implementation of procedures aimed to materialize products and services which stamp market value. This process marks the symbolic realm with the construction of a particular symbol system that, once it is entrenched, removes all traces of experience from the scene of scientific knowledge. For the purpose of restoring the continuity between science and experience, it must be shed light on the fruitful interactions that the singular meanings established in the course of the scientific practice maintain with the abstract systematic structure that emerges as its completed form. In order to fill that gap, the proposed strategy is to articulate a conception of scientific education open to the aesthetic appreciation of symbolic artifacts of science. The transition from one rendering of physics dominated by its technical consequences to another which also grasps its aesthetic modes of working is guided through the analogy which is shown to exist between two processes, namely, one over which the aesthetic vision of an artifact of physics is being established in educational mediations and the course of the appreciation of performances of a piece of music. By taking the route this analogy suggests, a picture of physics teaching as a performance art springs out.

Keywords: Physics - Study and teaching; Aesthetics; Construction of knowledge; Formation of the individual; Scientific language 


\section{Sumário}

Apresentação: 8

Capítulo I: Imaginação e confecção de mundos nas artes e ciências

26

Capítulo II: Considerações epistemológicas acerca do conteúdo da experiência estética

53

Capítulo III: A apreciação estética de peças de conhecimento científico ou, por que o conhecimento científico pode ser belo

80

Capítulo IV: Uma analogia para compreender o processo da experiência estética no ensino de física

109

Conclusão: Estética e aprendizagem da ciência: aspectos relacionados a transformação, continuidade e situação das experiências dos estudantes

163

Referências bibliográficas: 168 


\section{Apresentação}

Ao afirmar o ideal do Belo como princípio da aprendizagem, corre-se o risco de transmitir a impressão de ignorar que uma aprendizagem seja, muitas vezes, instigada pela promessa de realização de outro objetivo qualquer, que nada tenha a ver com a experiência da beleza. É certo que se podem estabelecer outros tipos de vínculo ou de valor que seja lícito a uma pessoa conceder a um objeto de aprendizagem e pelos quais ela seja conduzida a buscá-lo. Assim, haverá, por exemplo, quem valorize um curso de culinária simplesmente por atender a uma necessidade circunstancial de prover sua própria nutrição - como no caso de alguém que esteja indo morar sozinho - sem cogitar de vê-la como um campo de realização de um prazer estético. Trata-se aí do predomínio de uma necessidade de cunho puramente instrumental. A pessoa, neste caso, vê na aprendizagem - a ser realizada por ela mesma ou por outras pessoas - um intermediário que a liga com uma vantagem material: seu assentimento aos requisitos que o intento impõe está fortemente condicionado pela utilidade que o resultado previsto possa vir a ter para si, como um indivíduo particular, ou para um dado grupo a que pertence, no sentido de que este resultado irá lhe render poderes aumentados sobre o ambiente e as circunstâncias em que se situa. As dificuldades inerentes ao empreendimento serão enfrentadas principalmente em razão de conseqüências produtivas que ele pode trazer para certos negócios pessoais, nas circunstâncias peculiares e muitas vezes transitórias em que os indivíduos envolvidos se vêem posicionados. A motivação que irá se transformar nas ações exigidas para aprender será então proveniente de uma fonte que se situa além dos elementos constitutivos e da dignidade própria dos saberes com que a pessoa fará contato. Para ela, o interesse ou valor residirão nos produtos práticos da aprendizagem por si sós, e pouca atenção será dirigida ao processo em que estes são construídos. Em casos assim, a interação mais forte é a que a pessoa realiza com o resultado, que a aprendizagem lhe permitirá alcançar, de produzir uma condição pretensamente mais favorável de um ponto de vista individual; esse resultado é o que passa a conferir o principal significado à sua busca.

Exceção feita aos perigos ideológicos e de exploração do homem pelo homem que podem estar escondidos nesta postura, em situações de coisificação em que o ser humano não participa da definição dos fins que determinam o que ele deve fazer e 
quando esses não se inscrevem entre os fins humanamente defensáveis, seria ingênuo, de outro modo, recusar a legitimidade dessa espécie de aprendizagem que serve como meio para a consecução de um objetivo útil e material, uma vez que isso faz parte da natureza de várias habilidades que se mostram importantes em muitos momentos da vida de uma pessoa. Não é essa a verdadeira questão, mas sim se seria da natureza de todo e qualquer objeto de aprendizagem, sob todas as circunstâncias, e para todas as pessoas a instrumentalização de resultados práticos, ou se, mesmo para as aprendizagens utilitárias, isso esgotaria todas as possibilidades, não restando outra superior ou inferior, como se se tratasse de alvo de uma classificação unívoca em uma categoria a priori. Algumas vezes, ou porque estejam alheios a isso, ou disso plenamente convencidos, certos indivíduos pretendem que a esse foco particular na utilidade, pertinente a algumas ocasiões peculiares, seja conferido um caráter absoluto e universal, a ponto de estendê-lo como o principal objetivo de todo e qualquer esforço para conhecer. Nestas situações, a prioridade dada às ambições circunstanciais e individuais ocupa tão completamente as ações do indivíduo e adquire uma dimensão tão dominante em sua busca que o faz cego para a percepção de aspectos de valor que poderiam ser achados ao longo do trajeto. Mais do que com finalidades primordialmente individuais, tais aspectos se relacionam a significados entesourados nos caminhos profundos percorridos na elaboração de práticas humanas compartilhadas.

De fato, há aprendizagens que se realizam subordinadas a objetivos essencialmente utilitários, cujo traço fundamental é a funcionalidade objetiva, a resposta que oferecem a problemas e demandas da vida material ligadas a circunstâncias individuais e históricas pontuais. Entretanto, igualmente certo é que existem propósitos de aprendizagem de outra categoria, qualitativamente diferente, cuja ênfase está posta sobre o despertar da capacidade perceptiva e interpretativa do sujeito, e cujo efeito é engajar o indivíduo na construção de significados que o auxiliem a desvelar a ordem de que faz parte. Aprender é por excelência realizar esforços pela dilatação de capacidades de auto-estruturação e estruturação do mundo; esforços para observar o modo como uma experiência ordenada do mundo é construída e como, desse processo de construção, tanto o indivíduo quanto o próprio mundo emergem progressivamente mais bem acabados e integrados um ao outro. À medida que certos aspectos de pessoas, coisas e acontecimentos dantes vistos como fragmentos independentes da realidade vão sendo tramados e lança-se luz sobre significados até então ocultos, o aprendiz segue 
munindo-se de critérios que o habilitam para a constituição lúcida de um projeto de vida que, com mais chance, estará voltado para o bem comum. Tal é o status superior a que é alçado o sujeito que realiza esta modalidade de aprendizagem, com benefícios extensivos a todos os demais sujeitos, com quem se encontra inseparavelmente interconectado. Eis aí, precisamente, o que distingue educação de instrução.

Comparando as duas qualidades de aprendizagem aludidas aqui, nota-se que a primeira é de caráter técnico, material, fragmentário e estático. A segunda, por sua vez, é de natureza estética, ética, relacional e transformacional.

Certos artefatos intelectuais, dos quais a Física é um exemplar, não podem ter seu sentido corretamente apreendido por uma aprendizagem da espécie referida por primeiro, impelida por uma visão que concentra o valor da aprendizagem fundamentalmente sobre a aquisição de vantagens materiais e/ou simbólicas do indivíduo dentro de seu ambiente. Quando a relação com este tipo de artefato é assim direcionada, estabelece-se uma compreensão tíbia e superficial, incapaz de dotar o indivíduo de esquemas interpretativos que aumentem o seu poder de percepção crítica e de intervenção transformadora e consciente sobre a realidade. Sem condições de travar um verdadeiro diálogo com o conhecimento, ele torna-se dócil a uma técnica, fica circunscrito a um retrato transitório e distorcido do objeto de conhecimento e da prática que lhe deu origem. O indivíduo perde, assim, sua condição de sujeito, pois não integra em si mesmo o conhecimento, mas apenas mantém com ele uma relação de servidão.

O tipo de processo e de objetivo educacional da ciência a que se alude é portador de uma riqueza que requer a busca de outra postura de interação com o conhecimento científico: um intercâmbio que viabilize a transformação do indivíduo em um verdadeiro sujeito de sua aprendizagem e lhe permita realizar um gesto de integração das suas experiências que estão em andamento com outras do passado; que, desta maneira, acarrete novas maneiras de perceber e de se relacionar com o mundo e remeta a uma compreensão mais profunda, sistêmica e refinada do mesmo. Uma interação que permita apreender a substância do saber em sua relação com o próprio sujeito e com outros objetos de conhecimento e aprendizagem, desvelando perspectivas sobre fatos e normas universais nas quais estes se comunicam com expectativas e com modos de sentir e de imaginar. Um intercurso que, desde o início, prenuncie a conquista de um estado de consciência mais dilatada, em que o sujeito estará admitido no segredo das 
coisas. Sobretudo, uma participação apta a produzir a certeza de que as coisas possuem segredos e de que a capacidade de penetrá-los confere profunda dignidade à condição humana.

Esta modalidade de transação da pessoa com aquilo que se põe a aprender é contemplada em experiências estéticas de conteúdo cognitivo e normativo; nestas, os fatos e normas de uma disciplina científica não se apresentam simplesmente como elementos neutros que devem ser racionalmente assimilados, mas passam à condição de entidades cujo significado total é constituído em relações dos aspectos racionais com perspectivas ligadas ao sentimento e à imaginação; o afetivo e o racional firmam um elo que fecunda de sentido o objeto do conhecimento na sua relação com os indivíduos que partilham de um esforço de formação. A assinatura pela qual o processo de cognição estética vem a ser reconhecido pelo sujeito que a realiza é uma compreensão nítida de que deve conhecer porque está inserido em relações solidárias com o conhecimento, existindo um em função do outro. A compreensão de que essa relação é uma lei inescapável na ordem da qual é parte. Em outras palavras, o ser humano está presente nesta ordem exatamente para conhecê-la, o que significa explorar algumas das infinitas possibilidades e recursos de geração de significado para ela. Seu papel é conhecer, em níveis cada vez mais profundos e completos, a ordem do todo. Reciprocamente, a ordem existe em condições que lhe permitem seja sondada pelos sujeitos dela participantes. Portanto, para cada coisa ou fato ou aspecto da totalidade, corresponde uma ou mais capacidades potenciais do sujeito para apreendê-los e interagir com eles. $\mathrm{O}$ desenvolvimento de processos de experiência com conteúdos estéticos e cognitivos entrelaçados aparece, portanto, como princípio e como finalidade de uma concepção educacional que entende que os esforços da educação devem estar voltados para instilar no sujeito a idéia de que capacidades insuspeitadas dormitam nele em estado potencial, à espera de serem realizadas. Esforços não apenas para desencadear tal processo, mas, principalmente, dar subsídios para que o sujeito inscreva em definitivo o Belo em seu projeto de vida e possa dar início a uma busca que dure por sua vida toda. Defende-se aqui a idéia de que educar seria apoiar a criação da certeza de que a passagem do ser humano pelo mundo impõe o esforço incessante de realização destas capacidades produtoras de compreensão que, tendo seu desenvolvimento truncado ou desequilibrado, põem a própria humanidade do sujeito em risco, impedindo o fluxo 
normal de sua perfectibilidade e autonomia, e podendo até mesmo conduzir essa humanidade a um estado de morbidez.

Dá-se aqui por assente que o desenvolvimento de uma postura afetiva e valorativa em relação a elementos factuais - tais como os conteúdos dos saberes científicos - decorre diretamente da arquitetura que as relações entre mente e mundo vieram a assumir como resultado de centenas de milênios de evolução e história do ser humano: em virtude dessa arquitetura, as faculdades mentais humanas não conhecem partições ao se projetar rumo à produção de significado para os elementos do mundo. $\mathrm{O}$ pressuposto básico de que se parte é, portanto, o de que a percepção da realização da beleza no conhecimento científico e, em particular, no conhecimento da Física, não é um complemento à aprendizagem ou um epifenômeno, senão a condição, o princípio essencial para uma aprendizagem duradoura e transformadora do sujeito e que, como tal, deve ser enunciada como uma finalidade intencional, explícita da educação científica. Assumindo esse pressuposto básico, impõe-se, naturalmente, a pergunta de como os esforços da educação formal podem ser organizados para atingir essa finalidade, levando em conta, explicitamente, as circunstâncias específicas dadas no panorama atual da educação no Brasil e no mundo.

Com o objetivo de contribuir para a elucidação desta pergunta, o trabalho é voltado à formulação de uma moldura teórica adequada para interpretar o processo em que se dá a integração entre cognição e estética na educação em ciências. A partir dos esforços de caracterização dos papéis que a estética vem a desempenhar nas interações de estudantes com uma peça de conhecimento físico mediada por um intérprete resulta o esboço de um modelo que permite compreender os elementos específicos, e suas relações, que exercem influência sobre a realização da percepção estética em processos bem sucedidos de participação na educação. Pretende-se investigar as condições e mecanismos das interações de um sujeito aprendiz com o ideal do Belo no conhecimento científico. Para tanto, um dos pilares é a análise de situações reais de aula de ciências feita por um estudioso da educação científica, o sueco Per-Olof Wickman (2006). Ao mesmo tempo, os argumentos aqui desenvolvidos se assentam em exemplares de reflexão filosófica que não partem de um postulado universal de dicotomia entre razão e afetividade, entre objetivo e subjetivo, mas que demonstram aptidão para levar em conta o conhecimento científico e os saberes da experiência como partes integrantes de totalidades mais complexas. Tendo essa compreensão em mente, 
busca-se estabelecer diálogos entre alguns autores cuja obra está ligada ao entendimento do significado da experiência estética e seu lugar frente aos empreendimentos humanos de significação do mundo; neste intento, tomam-se para alicerces a estética pragmatista de John Dewey (2005), a visão do caráter situado da produção de significado pela perspectiva de Ludwig Wittgenstein (1967) e a abrangente análise semiótica do conhecimento avançada por Nelson Goodman (1976; 1978). Nas transações de pessoas engajadas em atividades com propósito de desenvolver modos de ver estética e cognitivamente informados - tal como se defende que a educação em ciências deva ser - caberá às representações da apreciação estética de obras de arte, e em especial de obras musicais, fornecerem a analogia fundamental para balizar a compreensão e a ação. No trajeto a ser percorrido, um requisito para o alcance dos interesses mencionados será compreender as ações e os procedimentos práticos e simbólicos envolvidos no estabelecimento da experiência estética.

Para uma compreensão judiciosa do cenário em que se acham inscritos os interesses e metas estabelecidos por este trabalho, é fundamental que, como preparação, seja feita uma reflexão sobre alguns aspectos marcantes que condicionam fortemente a compreensão que o relacionamento entre estética e ciência tem recebido do público geral e também por boa parte do público especializado.

1. A interferência de critérios estéticos na avaliação de teorias científicas é um traço que permeia a prática científica e que, até aqui, ao menos no Brasil, tem recebido atenção insuficiente por parte das análises que visam a entender criticamente os fatores que determinam a dinâmica dessa prática.

Parte-se da premissa de que a percepção de "como" a ciência executa o seu projeto e de quais atitudes face ao mundo este projeto supõe é tão relevante, do ponto de vista dos objetivos valorizados no processo de amadurecimento da cultura humana, quanto adquirir conhecimento sobre "o quê" a atividade científica produziu em termos de respostas e técnicas. As estratégias peculiares que a ciência produziu para tratar as perguntas que o ser humano se faz a respeito do cenário em que se percebe atuando passam desde o princípio por um processo de discussão em que o que está em jogo são valores e concepções de como a natureza deve ser e se comportar. As referências à 
valorização de atributos como elegância, simplicidade e simetria são recorrentes nos lances em que foram consolidadas peças fundamentais para a estruturação do corpus da física. Em que pese a atuação sistemática de valores estéticos durante toda evolução histórica da física, oportunidades de trazê-los à tona de modo a contribuir com uma compreensão mais completa e fiel do empreendimento científico têm sido negligenciadas.

2. Em consequiência do quadro anteriormente exposto de uma virtual ausência de análises dirigidas a capturar a atuação decisiva dos valores estéticos no desenvolvimento científico, a mesma ausência tem sido estendida para a problematização do papel que a percepção desses valores tem a desempenhar no desenvolvimento cognitivo e afetivo dos estudantes em todos os níveis e de sua significação ampla para a preservação do que de melhor a ciência já acumulou para o patrimônio cultural humano.

No contexto atual das pesquisas em educação em ciências, têm grande relevância para as discussões em torno do que vem a ser uma formação científica desejável os esforços de investigação com objetivo de lançar luz sobre a presença ativa da avaliação estética de teorias e modelos na prática da ciência. Entre outros corolários, de tais esforços deverá brotar todo um campo de pesquisa em educação em ciências, com suas preocupações voltadas para entender e intervir sobre determinado processo, atualmente em marcha no cerne da civilização, de graves repercussões para o espírito científico: o descolamento cada vez maior que se dá entre o cabedal de posturas e valores estéticos que, até aqui, têm presidido o empreendimento científico em sua luta para estabelecer uma visão ordenada de mundo e que se centra, sobretudo, em torno do valor de coerência, e a distribuição de valores que efetivamente informa escolhas de pensamento e ação dos indivíduos no cotidiano. Conforme aponta Habermas, é cada vez maior a separação entre a vida cotidiana e o mundo da cultura: “(...) cresce a distância entre os especialistas da cultura e o público em geral. Aquilo que se acrescenta à cultura, mediante elaboração e reflexão, não chega sem mais ao domínio da prática do 
dia-a-dia" ${ }^{1}$. Todo exemplar de pensamento científico está calcado em uma mesma postura intelectual básica sobre a qual atualmente paira uma séria ameaça em virtude dos rumos que o processo civilizatório demonstra tomar. A ciência tal como ela se estabelece a partir da modernidade tem como pilar o princípio de que todas as manifestações naturais estão estruturadas por uma ordem racional universal, coerente consigo mesma, à qual o ser humano busca fazer alusão por intermédio de construtos lógico-empíricos. Desse modo, as tentativas de solução de cada pequeno problema no âmbito da ciência se inserem em uma intrincada rede, que se prolonga horizontal e verticalmente, com o fim expresso de construir uma estrutura teórica unificada, coerente e lógica que ordene o maior e mais variado possível espectro de enunciados empíricos. Em contrapartida, verifica-se que práticas sociais, formas de vida e regimes de funcionamento psíquico emergentes vêm colonizando o âmbito da vida cotidiana sob a influência cada vez mais determinante do relacionamento das coletividades com os sistemas de informação e comunicação. Por viver exatamente da multiplicação desordenada da informação descontextualizada, sem uma origem identificável e sob a forma de sucessivos estímulos instantâneos e incoerentes, essa cultura midiática coloca poderosas pressões sobre os valores que fundamentam o projeto da ciência. Conhecer as forças motrizes desse processo de fratura no sistema de valores que orientam a prática científica é, portanto, condição essencial para que a Escola possa fazer sua parte na tarefa de garantir a sobrevivência de um patrimônio cultural que a humanidade levou séculos para construir.

No que diz respeito diretamente ao ensino de ciências, importa reconhecer que o fenômeno em questão é atualmente uma pré-condição básica colocada à aprendizagem de qualquer disciplina científica. Isso porque sempre que se observa em um indivíduo o domínio da operação com os conceitos, princípios e idéias de uma teoria ou modelo teórico há a certeza de que nele, em algum momento, foi deflagrado um processo primário de inserção na cultura científica. Este processo constitui o alicerce que suscita no indivíduo a formação de idéias básicas a respeito do sentido dos jogos de linguagem da ciência como dinâmica de construção de uma visão estruturada do mundo, no qual as observações desse mundo se alteram e se intensificam ao serem articuladas a mecanismos e causas. Em outras palavras, a ciência é, antes de tudo, um modo de agir e

\footnotetext{
${ }^{1}$ Habermas, J. Modernidade - Um Projeto Inacabado. In ARANTES, O. B. \& P. E. Um ponto cego no projeto moderno de Jürgen Habermas. São Paulo: Brasiliense, 1992, p. 110.
} 
de usar a linguagem, de pensar e de operar mentalmente, atrelado a um bem definido e básico juízo de valor sobre a própria ciência: o indivíduo ganha a intuição de que a ciência não só é como tem de ser um sistema abstrato estruturado e coerente.

Ao desenvolver sua abordagem para a compreensão do processo pelo qual questões são admitidas e descartadas por um cenário de investigação científica, Nicholas Jardine nos explica que, a fim de que um determinado conjunto de questões possa se tornar inteligível para um intérprete, é necessário que este consiga se inserir em um quadro cognitivo correspondente. Jardine refere-se à totalidade das crenças e compromissos que definem uma comunidade, gerando uma perspectiva a partir da qual certas questões tornam-se válidas e inteligíveis. Uma parcela destes compromissos é de ordem estética. Incluídos no quadro cognitivo encontram-se ainda distinções normativas, consensos sobre o tipo de consideração que é admitido pela comunidade para oferecer suporte a uma afirmação - isto é, sobre o que faz certas considerações serem relevantes e outras não para as questões levantadas no seio dessa comunidade - e também a compreensão dos princípios que justificam essa relevância. O mesmo Jardine chama atenção para linhas de pensamento ligadas à tradição da fenomenologia, como as de Husserl e Heidegger, que estabeleceram para si o projeto de pôr em evidência “'estruturas' e pré-entendimentos' que constituem horizontes dentro dos quais se torna possível para nós ter experiência articulada e levantar determinadas questões a respeito do mundo" (Jardine, p. 67). Sua abordagem segue próxima a Heidegger, que opta por construir uma noção mais relativista de inteligibilidade, lançando luz sobre "horizontes mais locais e específicos, tendo a ver com modos ordinários e cotidianos de envolvimento, interesse, interação e expectativa". Desse modo, para serem abertos, tais horizontes de entendimento exigiriam "não um ato de intuição, mas um processo de interpretação" (p. 68).

Transpondo considerações como essas para o âmbito do ensino de ciências, vêse claramente a importância fundamental do processo de desenvolvimento do sentido, ainda que tácito, do jogo científico e de suas regras, como um processo que deve andar em compasso com a aquisição de conhecimentos científicos específicos. Uma vez de posse do sentido desse jogo, ainda que inconscientemente, o indivíduo passa a fazer uso permanente do modelo de pensamento apreendido, que lhe dá a referência para seguir e refazer os raciocínios envolvidos na abordagem de tal ou qual peça de conhecimento científico. É assim que ele tem condições de elaborar sua própria versão dos 
significados e das conseqüências de um determinado teorema, de um determinado experimento ou esquema explicativo. Não obstante, há indícios de que o processo cultural ou de experiência mediante o qual esse julgamento de referência se efetiva, se estabelece com firmeza na consciência do indivíduo comum, em sua interação com a escolarização, com a sociedade e com a cultura de maneira mais ampla, encontra-se no momento em corrosão. Simultaneamente ao encontro com os fatos científicos, é necessário estabelecer vínculos de significado com os valores que fundam a ciência. Por hipótese, antes mesmo de atingir o ponto de se confrontar com os desafios específicos envolvidos na aprendizagem deste ou daquele raciocínio, operação ou conceito, a dificuldade fundamental que se impõe ao estudante de ciências nos dias atuais liga-se ao fato de lhe escaparem os valores e atitudes de referência necessários para saber se orientar no contexto de uma cultura de natureza oposta àquela com a qual se acha comprometido no dia a dia. Que, em alguma medida, os valores aludidos são valores estéticos torna-se evidente pelo simples modo que os estudantes têm de expressar seu desagrado em relação às disciplinas científicas do currículo escolar. Estudos com foco sobre a interveniência de aspectos culturais na educação em ciências oferecem suporte a esta suposição. Um destes trabalhos, realizado por Aikenhead e Cobern, traz um relato em que ficam evidentes os vigorosos impedimentos à participação de uma estudante na aprendizagem da ciência provocados pelo choque entre as expectativas e significados da vida cotidiana e uma educação científica que, mediante escolhas curriculares cognitivistas, impõe austera e bruscamente a mensagem de indiferença da natureza em relação à existência humana. Ao ser entrevistada por um dos pesquisadores, a menina deixou claro que, em sua visão, a aula de ciências não tinha a ver com a natureza, já que esta para ela era "algo amigável de que a gente pode fazer parte com alegria" ${ }^{2}$. Sobre este depoimento, Wickman (2006, p. 45) observa que, "Para essa menina, aprender ciência parecia ser não só uma questão de aprender fatos e conceitos”.

Ainda sobre esse aspecto, "A estética de um professor pode até mesmo dizer a certo grupo de estudantes que a ciência não é nada que seja do interesse desse grupopor exemplo, se ela se colocar como uma experiência de ameaça à identidade deles", ressalta Wickman (p. 157). A famigerada e temida pergunta que estudantes costumam

\footnotetext{
${ }^{2}$ Cobern, W. W., \& Aikenhead, G. S. Cultural aspects of learning science. In B. J. Fraser \& K. Tobin (Eds.), The international handbook of science education, pp. 39-52. Dordrecht: Kluwer Academic, 1998. Citado por Wickman (2006).
} 
fazer a seus professores "Para que serve aprender ciência?" pode ser traduzida como uma indagação sobre se poderiam existir compatibilidades entre, de um lado, o modo como aquele professor se relaciona com sua disciplina para encontrar motivação e satisfação no conhecimento científico e, de outro, o sistema de valores dos grupos com os quais o estudante se identifica. É, pois, uma investigação que o estudante realiza com o propósito de testar quais são as expectativas que ele ou ela pode nutrir quanto à viabilidade de encontrar um lugar para si dentro de atividades relacionadas com a ciência. Sob esse prisma, muitos dos gestos e decisões do professor, podendo ser de sua própria iniciativa ou em resposta a movimentos dos estudantes, funcionam como modo de dizer ou mostrar um "estilo" de comportamento representativo do que é próprio aos participantes de práticas que incluem o conhecimento científico. Um exemplo de como certas distinções de gosto servem para definir o pertencimento ou não a um círculo de pessoas que partilham de um estilo pode ser visto, como aponta Wickman, nos momentos de uma aula em que uma pergunta ou comentário feito por um estudante são coletivamente julgados com respeito a serem interessantes ou triviais.

Assim, cabe à pesquisa em ensino de ciências, primeiramente identificar sinais da interferência de fenômenos dessa natureza na aprendizagem das ciências, e em seguida investigar meios para abordar, antes de tudo, o processo de inserção nos valores de referência da cultura científica - e entre eles os valores estéticos - do qual depende toda a aprendizagem da ciência. A presente pesquisa atravessa ambos os níveis, mas principalmente o segundo, investigando como e em que medida é possível o ensinoaprendizagem da apreciação estética da ciência.

3. A ausência de uma preocupação teórica mais detida com relação ao espaço cada vez maior que se abre entre os sistemas de valor da ciência e do indivíduo no cotidiano também pode ser explicada por resquícios tenazes de uma concepção epistemológica incoerente segundo a qual a ciência é fruto da total primazia de um método único e predefinido sobre a prática dos cientistas - concepção esta que por vezes é surpreendida em ações e falas que denunciam sua sobrevivência até mesmo nas atitudes em relação ao conhecimento mantidas pelos integrantes de círculos científicos que se esforçam por derrotá-la. 
Apesar de tudo o que já se avançou, desde o advento da teoria da relatividade restrita em 1905, no campo da reflexão epistemológica, tendo como resultado dar ao ser humano um retrato mais perfeito de como a ciência se constrói e se reconstrói, os espectros das concepções positivistas ainda podem ser vistos por aí assombrando até mesmo muitos dos que já se imaginavam imunes às suas sugestões. Somos herdeiros de uma racionalidade técnica que se mostrou tremendamente eficaz no domínio das forças da natureza. Por isso mesmo, justifica-se o enorme poder de cooptação de que goza essa modalidade da razão entre todos, e o pathos que ela suscita como única forma válida e produtiva de exercício da racionalidade. Conforme comenta Franklin Leopoldo e Silva (1997), “devido à identificação entre conhecimento e dominação, a instrumentalização acaba recobrindo a totalidade do que se entende por exercício da racionalidade". Em razão disso, costuma-se eleger como critério exclusivo - ou, no mínimo, o mais decisivo - de avaliação do conhecimento a sua capacidade de manipular os objetos sobre os quais ele é formado. Desde o princípio, a ciência moderna foi absorvida por processos de transformação da civilização ocidental comandados pelo poder político e econômico. Daí que, de tudo o que está incluído no exercício da prática científica, ficassem enfatizadas especialmente suas conseqüências para o propósito do controle e da previsão, necessários ao aumento da eficiência na produção e na guerra. O interesse, ou ênfase, no controle facultado pela tecnociência se constituiu no fator determinante para a definição do valor primordial emprestado publicamente ao conhecimento científico. Guiado pelo vulto que este valor de manipulação passa a ter nas práticas e formas de vida humanas e na configuração da própria natureza, o público é levado a aderir a hábitos de distinção que direcionam o foco da atenção dos indivíduos exclusivamente para aqueles aspectos do empreendimento científico estritamente vinculados à eficácia da razão por oposição à experiência e aos significados humanos. Assim, a ciência entra para a cultura com o significado de prática que se define por um compromisso único com a objetividade e a universalidade, ao mesmo tempo em que a visibilidade do espaço da experiência, na atividade científica e na vida em geral, vai se tornando cada vez mais reduzida. Deste modo, fomos ensinados que, para ser ao mesmo tempo legítimo e confiável, o conhecimento precisa ser objetivo e universal. Na perspectiva da teoria dos símbolos de Nelson Goodman, este quadro se consolida pela atuação de processos que conduzem o público a adquirir proficiência no uso de um sistema de símbolos particular para interpretar os artefatos simbólicos da ciência. À luz desse sistema, as apresentações concretas do conhecimento científico são lidas como 
amostras que exemplificam controle e manipulação, mas não são tomadas como exemplares ou modelos de harmonia, profundidade, grandiosidade ou dramaticidade. No auge desse processo na modernidade avançada, o conhecimento científico somente pode falar de modo imediato às pessoas se for como técnica.

Devido à preocupação primeira com a manipulação, passamos a entender por objetivo o conhecimento reprodutível, quer dizer, o conhecimento que em princípio permite a repetição das condições nas quais ele se verifica. Para a garantia da reprodutibilidade, deu-se um deslocamento em direção a anatematizar e considerar espúria toda e qualquer interferência de valores sobre a esfera dos processos de determinação de fatos. Assim, em virtude da pretensão de alcançar a independência em relação ao que é próprio dos sujeitos que exercem o ato de conhecer, o conhecimento objetivo foi proclamado neutro, isento de valores. Outro modo de dizer isso é afirmar que juízos de fato devem ser dissociados de juízos de valor, ou ainda, que a racionalidade técnica não trava contato com nada que diga respeito a julgamentos e avaliações em termos das categorias de agradável, amável, bom e belo. Além disso, para obter o certificado de fidedignidade, o conhecimento também precisa ser traduzido em regras generalizáveis, passíveis de serem estendidas, senão a todas, a um número amplo de situações particulares. Por causa destas exigências, todos os investigadores concordam que devem limitar sua atenção ao conjunto seleto daquelas facetas dos objetos que dão espaço a um programa de aplicação de um método universal. Opera-se, com isso, a redução do objeto de conhecimento àquela parte do mesmo que possui esses atributos específicos. A conclusão é que, para o conhecimento assim entendido ser possível, todo objeto deve, necessariamente, ser tratado como coisa, ou seja, algo passível de manipulação.

Desse modo, os sintomas da valorização excessiva da informação em detrimento da experiência rapidamente se infiltram no campo do pensamento pedagógico sob a forma de um cognitivismo que se pode apreender em terminologias como "sociedade da informação, do conhecimento ou da aprendizagem" ou ainda, na psicologia da aprendizagem, em expressões como "estrutura cognitiva" ou "representações mentais", orientadas por concepções representacionalistas do conhecimento. Opera-se, assim, a distorção e degeneração do processo educativo em meras estratégias de aquisição e processamento de informações, que visam aos fins da técnica e do mercado, jamais aos fins humanos. Como antídoto para a razão manipulatória hipertrofiada, incapaz de 
alimentar e iluminar a existência humana, fascinada pela crença no progresso pela técnica e que prega a objetividade exatamente porque esta lhe garante a satisfação de sua ânsia de controle da natureza e do homem, a experiência é a afirmação da necessidade de salvaguardar a subjetividade, o apaixonar-se e entregar-se às coisas indispensável à construção dos significados e da riqueza de cada existência singular. Ela é o elemento de equilíbrio que abre ao ser humano a possibilidade de narrar e de se apropriar de sua existência. O saber da experiência é um saber encarnado na vida. Nesse território, não pode haver certezas quanto ao ponto a que as experiências levarão o indivíduo, que responde ao que vai lhe acontecendo de acordo com a rede de sentidos de que já se apropriou ao longo da vida e modifica essa mesma rede continuamente no contato com as novas experiências. Porém, apesar de haver uma incerteza irredutível, o estado de receptividade que faculta a experiência proporciona um enriquecimento pela apreensão significativa do elemento inesperado. Ao mesmo tempo, o saber da experiência é o conhecimento que permite um comprometimento mais genuíno, mais vital com a ação. Esse saber, por suas conexões estreitas com os sentidos mais cruciais para o sujeito singular que o detém, fecha a lacuna de significado inerente ao conhecimento que se volta para a realização de finalidades de cunho puramente utilitário e viabiliza uma adesão livre e essencial dos sujeitos individuais ou sociais a suas práticas.

4. A confusão entre juízo estético e predileção individual arbitrária é muito freqüente no senso comum, impedindo a correta interpretação da avaliação estética na ciência. Além de chamar atenção para o papel central que valores de variadas espécies desempenham no processo de ensino-aprendizagem das ciências, é necessário se voltar para a elucidação da natureza e dos mecanismos próprios ao juízo estético. Com a compreensão aperfeiçoada dos atributos definidores desta modalidade de juízo, abre-se a perspectiva de eleger uma metodologia adequada à abordagem da apreciação estética no ensinoaprendizagem da física.

Há, assim, dois planos diferentes que se interceptam no problema de investigar a experiência do Belo face à apreciação do conhecimento científico e do processo de 
estruturação desse conhecimento. O primeiro diz respeito à verificação da pertinência e necessidade de que tal relação com o saber científico seja desenvolvida pelas pessoas. Quanto a isso, talvez exista uma boa-vontade maior. Mais problemático é o segundo plano, que incide sobre a viabilidade de compreender como essa relação é posta em marcha, considerando a presumida ausência total de características que possam ser compartilhadas pelos processos de fruição desencadeados em diferentes indivíduos. Uma pergunta que é imediatamente sugerida ao refletir sobre o estatuto da avaliação estética de um objeto - seja este uma obra, uma experiência ou um sistema teórico abstrato - é se as avaliações desta espécie não deverão ser necessariamente subjetivas, isto é, influenciadas principalmente pelas idiossincrasias e modos particulares que cada pessoa tem de perceber e sentir a beleza, e, portanto, sem significado verdadeiro. Em outras palavras, aquilo que para uns é visto como genuína manifestação da beleza, para outros nenhum encanto ou entusiasmo pode inspirar: "A beleza está no olho de quem vê". Sendo assim, tende-se automaticamente a desconfiar da existência de algum sentido em considerar seriamente a possibilidade de uma educação que contemple o objetivo de desenvolver nos indivíduos a capacidade de perceber o Belo, e ainda mais da possibilidade de empreender qualquer tentativa de capturar sistematicamente a atuação dos valores estéticos na ciência, já que este Belo é necessariamente fugidio ou talvez até mesmo não exista.

Dois esclarecimentos fazem-se necessários a fim de dissipar essa confusão. Primeiramente, um retorno às observações feitas sob os itens (1) e (2) permite ver que o atributo de neutralidade está mais para um ideal utópico com o qual essa racionalidade manipulatória pretende se adornar do que para uma caracterização da sua real condição. Julgamentos e avaliações embasados em valores de diferentes naturezas se fazem presentes o tempo todo na atividade científica, determinando de muitas maneiras as decisões e ações inerentes aos atos de criação do conhecimento, assim como as inerentes à sua justificação. Ao lado de critérios lógicos e empíricos, os critérios estéticos e normativos tomam parte na definição de problemas de pesquisa, na escolha dos itinerários de solução e também na avaliação e aceitação de teorias. Em segundo lugar, o fato de o objeto de estudo em visada não obedecer de forma estrita aos requisitos de neutralidade, reprodutibilidade, generalidade e unicidade não deve implicar em identificar automaticamente os julgamentos estéticos envolvidos à mera preferência idiossincrática e arbitrária. Tal argumento já não se mantém de pé em 
relação às avaliações esteticamente relevantes de objetos de arte, e permanece insustentável no terreno da apreciação estética de peças do conhecimento científico. A viabilidade de apreender o modo de atuação de valores estéticos na avaliação de teorias por intermédio de um modelo racional tampouco fica comprometida.

Ao longo da sua história, a humanidade criou e acumulou coletivamente códigos a serem utilizados em leituras e interpretações dos conteúdos que podem ser encontrados nas mais variadas experiências do gênero humano e perante os mais variados objetos que o acompanham em sua jornada de significação da realidade. Porém, uma pessoa somente torna-se apta a compreender o significado de determinadas experiências se ela houver sido integrada para participar de horizontes dentro dos quais essas experiências são significativas. A chave para a incursão no território da beleza está justamente naquilo que é descartado pelo conhecimento instrumental: os valores e os significados existenciais para os indivíduos e a sua interação com os valores e significados presentes no contexto cultural; em suma, os significados de experiência. Logo, enunciar a percepção da beleza como objetivo de aprendizagem no ensino de física pressupõe: 1. considerar a física como parte da cultura humana, em geral, e como parte de experiências que os estudantes podem compartilhar; 2. mostrar os diálogos, as relações que se estabelecem na construção do conhecimento da física entre fatos, normas e valores; 3. observar o papel que situações e significados singulares têm a desempenhar para a aprendizagem dos fatos científicos propriamente ditos.

Deste modo, o aspecto privilegiado aqui será pavimentar caminhos para a apreensão de uma mensagem estética implícita na tarefa da ciência, tão importante para constituição deste exemplar da atividade humana quanto as realizações teóricas e tecnológicas diretamente colimadas através dela. A pesquisa se dirige a dar contribuições para um ensino da física que vise - pari passu com os objetivos de operacionalização - a oferecer ao estudante a oportunidade de criar uma compreensão mais abrangente da ciência como manifestação que se interliga a outras manifestações da cultura e o prazer de contemplar atributos que dão o direito de classificá-la entre as fontes de experiências estéticas do mundo. Ao buscar esse objetivo, parte-se do pressuposto de que a aprendizagem estética deve ser defendida, sobretudo, porque promove, de modo solidário e inextrincável, os valores da ciência e da sensibilidade, contribuindo para colocar em acordo estas duas facetas da atividade humana com que o 
homem significa sua realidade e que, até aqui - com prejuízo para ambas - têm permanecido antagônicas e seguido caminhos independentes.

5. O Belo e o saber científico são plenamente conciliáveis e promotores um do outro também no que diz respeito ao aprender ciência. Do ponto de vista da experiência estética, não há dicotomia entre intelecto e sensibilidade, ou entre reflexão e experiência. Do lado da aprendizagem da ciência, o uso de capacidades puramente cognitivas demonstra ser uma abstração analítica; a aprendizagem faz recurso ao cognitivo integrado a outras capacidades do ser humano, com destaque para a percepção, a imaginação e as emoções.

A percepção da beleza passa necessariamente pela atuação das faculdades cognitivas do sujeito dessa percepção, combinadas aos sentidos e às emoções. A beleza é indissociavelmente objeto da inteligência. No entanto, embora seja condição sine qua non para abrir caminhos de acesso à experiência do Belo na aprendizagem da física, a estruturação do intelecto é por si só insuficiente. Conforme percebeu Kant, avalia-se um objeto como belo na medida em que se desencadeia um jogo harmonioso e livre entre os poderes da imaginação sinóptica e metafórica e do entendimento discursivo e literal do sujeito da percepção estética. Deve ser estimulada, portanto, a atividade imaginativa em que o sujeito jogue com os significados da Física que se apresentam para a cultura contemporânea. Os diferentes aspectos e significados das teorias da física são peças que oferecem múltiplas possibilidades de movimentos das faculdades mentais - incluindo também, mas não somente a cognição - em termos de fazer distinções, encontrar similaridades, ter a percepção de expectativas e de consumações. Desde que harmoniosamente coordenados, esses movimentos provocam em uma pessoa que participa da experiência da construção de conhecimento da física a reação de surpresa e admiração com respeito à dimensão estética deste mesmo conhecimento. Neste sentido, jogar é remexer, reordenar, recombinar, reorganizar, testar, explorar, manipular um acervo de experiências, significados, interpretações, leituras e informações, ao ser exposto aos objetos e eventos inseridos em uma atividade provocadora. Nesta atividade lúdica da mente, há uma alternância contínua entre os pólos do sujeito e do objeto: o objeto sugere possibilidades ao ser manipulado e, inicialmente comanda a relação; em 
seguida, o comando passa ao sujeito que começa a explorar o objeto, dentro das limitações que este lhe impõe, mas como um ato de vontade. A exploração dos movimentos permitidos por estas peças realiza a expansão de aptidões humanas, incitando um sentimento de realização na pessoa que participa deste jogo. A percepção da dignidade do conhecimento científico em si mesmo vai se estabelecendo à medida que se desenrola esse processo e tornando a promover o desejo de apreender. Se a educação científica corteja o objetivo de criar condições para que o indivíduo assuma a posição de sujeito interlocutor no encontro com o saber científico, ela deve investir nas capacidades de percepção, imaginação e interpretação do aprendiz: somente assim o conhecimento gera significado existencial. Os significados existenciais assim gerados retroalimentam o desejo de continuar apreendendo. 


\section{Imaginação e confecção de mundos nas artes e ciências}

Até mesmo as ilhas se ligam no fundo do mar.

Muriel Rukeyser

Quando se trata de átomos, só se pode usar a linguagem

como a usamos na poesia. O poeta também está menos preocupado em descrever fatos do que em criar imagens.

Niels Bohr

\section{Introdução}

De uma maneira acelerada, no século $\mathrm{XX}$, o público viu as transformações históricas atravessadas pelos setores da arte e da ciência conduzirem ambas na direção de uma progressiva especialização, que o privava da possibilidade de acompanhar os planos e trajetórias seguidos pelo trabalho de cientistas e artistas. Em um aspecto importante, no entanto, a percepção pública dessas trajetórias pôde fazer uma distinção: se nos dois campos havia enormes barreiras impedindo a compreensão dos respectivos processos, ao menos a vida diária sentia os efeitos de transformação decorrentes dos produtos da atividade científica de modo muito mais vigoroso e abrangente em comparação aos resultados atingidos pelos esforços nas artes. Assistiu-se à ruidosa demonstração da capacidade da ciência de intervir - com a enorme ampliação de conhecimento sobre a natureza e com seus frutos tecnológicos - em todos os recantos da atividade humana, ao mesmo tempo em que se presenciou o arrefecimento da negatividade, do poder de inquietação e de subverter expectativas que havia sido inicialmente a marca dos movimentos artísticos de vanguarda. A imagem das artes perante a opinião do homem das ruas se reduziu finalmente a de uma recusa de intelectuais em viver a realidade, ou, quando muito, a de uma mera curiosidade. A participação na criação e na apreciação foi rapidamente perdendo terreno para o 
consumo passivo de formas edulcoradas de atividade cultural, afeitas à exploração comercial por uma voraz indústria do entretenimento de massas. A eficácia dos meios e processos de reprodução, divulgação e circulação envolvidos na captura da atenção do público foi culturalmente assimilada à conta de mais um potente indicador do triunfo dos valores e da ideologia da tecnociência, contribuindo para gravar profundamente no imaginário coletivo a necessária convergência - ou submissão - de toda vida humana para as finalidades da eficiência e do progresso econômico.

Com isso, a atividade imaginativa sofreu severas regressões nas camadas populares, enquanto a vitória do critério da verdade científica, objetiva e única, continuava a garantir níveis de lucratividade cada vez mais elevados para as elites econômicas. Igualmente premidos pela força desse curso histórico, os círculos científicos falharam em compreender e universalizar as profundas consequiências filosóficas legadas por avanços como, por exemplo, a relatividade e a mecânica quântica no âmbito da física, ou o pensamento complexo nas ciências da vida. A análise judiciosa destas realizações científicas expõe as enormes fragilidades das visões que alegam que os saberes sobre o mundo natural consistem em ordenações proposicionais sustentadas diretamente sobre a estrutura subjacente da realidade e capazes de espelhála fielmente. Como resultado de uma escolha em favor da concepção representacionalista do conhecimento da ciência, grande parte da comunidade científica se viu varrida pela crença na redutibilidade total à objetividade científica como a pedra de toque para aferir a validade de qualquer alegação de conhecimento. A bem conhecida propensão humana de buscar a verdade e o conhecimento únicos e absolutos expulsou todos os exemplares da ação humana criadora que teimavam em não se reduzir aos padrões de aceitação da ciência para o terreno da fantasia ou da mera ficção. As artes, em particular, podiam muito bem ser aceitas em sua dimensão lúdica, ou em sua ação distensiva, menos, porém, como forma legítima, disciplinada e consistente de conhecimento da realidade básica do mundo.

Em contrapartida, as manifestações do grau de controle do ambiente conquistado pelo ser humano ao fazer uso dos meios que a técnica lhe proporciona são não mais eloqüentes que as demonstrações do alcance dos riscos e incertezas na esteira do monopólio da racionalidade científica a que se assiste no estágio mais avançado da modernidade. De fato, o caráter contraditório, instável e reflexivo da modernidade é imanente aos seus princípios fundantes: o poder manipulatório da instrumentalização conjugado à idéia de progresso tende espontaneamente a sufocar outras expressões da 
prática e figuras da racionalidade humana. Concomitantemente, no plano epistemológico, não é de nenhum modo óbvio que a visão do empreendimento científico nos moldes da razão técnica seja a única possível, ou que seus métodos e critérios sejam merecedores de receber total prioridade em relação aos de outras formas de relacionamento epistêmico do ser humano com seu mundo. Investigações da história da ciência apontam de maneira unânime que a objetividade se revela muito mais uma idealização do que uma característica efetivamente presente na prática científica. $\mathrm{O}$ desenvolvimento das idéias da ciência vê-se condicionado por fatores relativos a lugares e momentos históricos peculiares. O padrão de verdade mostra-se por vezes estreito demais, dando lugar a outros critérios, como a possibilidade de construção de sistemas dotados de uma estrutura internamente consistente, em boa parte determinada por imposições arbitrárias de ênfases e organização conceitual. Mais que a verdade, o cientista procura por molduras teóricas capazes de resumir grandes massas de enunciados empíricos em uma mesma ordenação simples, abrangente e inteligível. Na maior parte dos casos, as teorias costumam surgir antes de qualquer evidência experimental vir a seu favor. E o que costuma ser referido como fato, sob uma análise mais profunda, assinala a marca das interpretações feitas à luz de uma determinada teoria.

Constatações desse tipo chamam atenção para a necessidade de revisão no modo de conceber o conhecimento, sugerindo ser possível que uma inspeção mais cuidadosa e livre do viés cientificista leve ao reconhecimento de versões complementares à ciência em figuras não menos legítimas de saber, sem que isso implique no afrouxamento do rigor em sua avaliação e fundamentação. Em uma concepção ampliada, seriam admitidas como legítimas todas as formas de aquisição de conhecimento com aptidão para induzir a reestruturações nos hábitos que guiam nossa visão de mundo, de modo a habilitá-la a apreender aspectos do mundo cada vez mais sutis e inusitados, que no princípio não estejam identificados, e a dilatar, com isso, o grau de liberdade do ser humano. A essa classe pertence o conhecimento científico, mas não somente ele: é imediato ver, por exemplo, que obras de arte na música, literatura, pintura, arquitetura, escultura, dança ou teatro são, por excelência, meios que operam na realidade, informando o olhar que o ser humano dirige para ela.

À primeira vista, no entanto, tal expansão do território do conhecimento gera uma dificuldade: as diferentes versões de mundo assim admitidas são muitas vezes conflitantes, visam a propósitos específicos diferentes e não sugerem nenhuma política 
óbvia quanto ao modo de integrá-las em uma estrutura epistemológica - e por que não metafísica? - coerente. A discussão desse problema é exatamente o propósito deste primeiro capítulo. Em particular, tem por objetivo investigar uma hipótese, a saber, a de que os campos da arte e da ciência são unidos por vínculos e afinidades básicas que, na maioria das vezes, têm passado despercebidos em razão da forte atitude reducionista e hierarquizante presente nos pressupostos culturais da modernidade. Como guias para a incursão neste domínio, foram selecionadas duas abordagens à questão que partem de ângulos diferentes, mas que alcançam boa margem de acordo em suas conclusões: de um lado, a análise construtivista do filósofo americano Nelson Goodman, a partir de sua teoria dos símbolos e funções simbólicas; de outro, a reflexão antropológica do matemático, lingüista e ensaísta Jacob Bronowski, que discute as artes e as ciências enquanto atividades que brotam naturalmente da capacidade definida por ele como o traço distintivo do humano: a imaginação.

\section{$2 \quad$ A multiplicidade de versões e visões de mundo}

A cognição humana é resultado de um complexo processo de composição a partir de elementos bastante heterogêneos. Os múltiplos aspectos em que a realidade se apresenta a cada ser humano são extraídos de versões e visões de mundo à disposição no âmbito da cultura, os quais povoam o mundo de sistemas de símbolos de diferentes naturezas e modos de funcionamento. Goodman argumenta para que se entenda que os itens de mundo e suas características de que o ser humano tem notícia não se proclamam a si mesmos e por si mesmos:

Nenhuma característica de qualquer coisa é tão central ou tão potencialmente proeminente a ponto de jamais passar sem ser notada, mesmo quando escrutinamos bem de perto e repetidamente. Aquilo que nós descobrimos, ou que temos êxito em construir, é pesadamente dependente de como e o que estamos procurando (Goodman, 1978, p.39).

Portanto, nenhum sistema de categorias e normas é diretamente ditado por uma ordem primitiva do real; cada um desses sistemas é necessariamente influenciado por escolhas humanas em termos de distinções, similaridades e ênfases. Essas escolhas não 
são únicas e, caso seja removido do conhecimento tudo aquilo que é tocado por interpretações fabricadas pelo ser humano, acaba-se perdendo qualquer imagem determinada do mundo. Além disso, nenhum desses sistemas é capaz de recobrir o mundo na integridade de seus aspectos: eles inevitavelmente constituem simplificações do real, com eficácia relativa a certos propósitos e valores, alvo igualmente de escolhas relativas. No caso da ciência, controle, manipulação e previsão estão entre os principais interesses. Por outro lado, o reconhecimento destes propósitos como valores relativos às versões de mundo da ciência não torna de nenhum modo menores os méritos das realizações científicas.

O acesso do ser humano ao mundo é, assim, necessariamente dependente da mediação efetuada por sistemas de símbolos que organizam um universo de versões e visões. Por versões e visões de mundo, Goodman se reporta à enorme variedade de artefatos intelectuais de compreensão construídos a partir de descrições, representações e exemplificações mediante as quais o ser humano faz referência ao mundo "nas diversas ciências, nos trabalhos de diferentes pintores e escritores, e em nossas percepções enquanto informadas por eles, pelas circunstâncias e por nossos próprios insights, interesses e experiências passadas" (Goodman, 1978, p. 3).

A tentativa de apreender o real - ou, melhor dizendo, de ter experiências estruturadas, dotadas de forma, significativas - sem o intermédio de nenhuma conceitualização, sem o auxílio das experiências coligidas no passado, ou mesmo sem poder recorrer à "forma de conceito sem conteúdo", como diz Kant em relação ao juízo de gosto, conduz fatalmente à paralisação da compreensão, a um vazio total. No entanto, o pensamento habitual possui a tendência de projetar a imagem de uma realidade predefinida e encarar nossa posição epistêmica em relação a ela segundo uma entre as seguintes alternativas: uma primeira que afirma a possibilidade de que esta realidade seja espelhada pela mente tal e qual é em si mesma, e que, portanto, todos os modos verdadeiros de conhecer, sejam eles quais forem, conseguem descrevê-la ou evidenciá-la ou retratá-la fielmente; e, de outro lado, uma de acordo com a qual a realidade não se deixaria ver em sua forma neutra ou absoluta, mas apenas mediante uma ou mais formas de conhecimento verdadeiro, embora particulares, cada qual capturando indiretamente ou gerando uma representação de um determinado conjunto de características do mundo. Em ambas as imagens do relacionamento epistêmico do ser humano com o mundo, a unidade deste último estaria assegurada. Isto porque, no caso de se admitir que o conhecimento verdadeiro se ache distribuído em dois ou mais 
sistemas, acreditar-se-ia possível, depois de a investigação ter prosseguido durante tempo suficiente, demonstrar ou a existência de um único sistema a que todos os demais se reduziriam, ou então que as visões oferecidas pelos sistemas distintos poderiam ser traduzidas umas nas outras consoante regras de transformação bem definidas e universais. A crença em uma realidade que se configura como uma unidade coerente está ligada ao desenvolvimento de uma noção de invariância. Esta invariância estaria por detrás da multiplicidade dos aspectos que são capturados a partir de pontos de vista particulares em que se posicionam os retratos que o ser humano faz em suas tentativas de agarrar o absoluto, e realizaria, desse modo, a integração das facetas parciais verdadeiras. Trocando em miúdos, trata-se da idéia de que, apesar das diferenças das visões e versões, todas as corretas estariam falando de uma mesma e única coisa, apenas que a partir de ângulos diferentes.

No que tange a primeira das formas de interpretação da realidade unitária, desde a entronização da visão de mundo newtoniana no século XVIII, e com ênfase ainda maior a partir da formulação da filosofia positivista no século XIX, observa-se que a física tem pleiteado para si o posto mais alto entre os empreendimentos intelectuais humanos; é algo que se pode depreender em muitos discursos oriundos do círculo da física a visão de que todos os ramos da atividade científica, incluindo as ciências humanas, deveriam tomar a física como modelo para o seu desenvolvimento e convergir para finalmente serem anexados a ela sob a forma de capítulos particulares. De outro lado, como exemplo da segunda postura aludida, a de relatividade, pode-se mencionar a abordagem do filósofo Ernst Cassirer. Em obras como Linguagem e Mito, Cassirer põese a investigar a unidade do conhecimento por meio de um estudo do desenvolvimento do mito, religião, língua, arte e ciência através de culturas humanas situadas em posições distintas no tempo e no espaço (Goodman, 1978, pp. 1-5).

Goodman faz objeções a formas de pensamento — segundo ele determinadas simplesmente pelo hábito - que enfatizam o pressuposto de que o real existe dentro de uma organização primitiva e eterna, e que, portanto, consagram uma concepção do mundo como um cenário que já se acha organizado de uma forma determinada anteriormente a qualquer tentativa feita para descrever essa organização. É enorme o peso sobre o senso comum da crença em uma verdade única e absoluta amarrada a um substrato ontológico objetivo. Primeiramente, Goodman é peremptório em afirmar que todo sistema de conhecimento seja nas artes, nas ciências ou na filosofia - e incluindo, logicamente, o seu - reflete necessariamente um ponto de vista particular e arbitrário e 
que, como tal, carece do poder de formar qualquer visão determinada de como a realidade se afigura em seu estado absoluto, do mesmo modo que a realidade de um movimento não é nenhuma das descrições que dele podem ser feitas a partir dos infinitos referenciais possíveis. Em outras palavras, no tocante à variedade de versões com as quais se busca adquirir conhecimento sobre o mundo, também é possível afirmar a inexistência de um análogo epistemológico do conceito de "éter", ou seja, de um sistema de referência absoluto para a justificação do conhecimento. Se for verdade, então, que existem diferentes versões de mundo corretas, mesmo que elas exibam a propriedade de se reduzirem a uma única ou de se traduzirem umas nas outras o retrato da realidade de um ponto de vista absoluto termina, de qualquer modo, escapando pela porta dos fundos; ao proceder no propósito de despir o conhecimento cristalizado em uma versão das sucessivas camadas de estipulação de que ele se acha coberto, terminase aniquilando totalmente a compreensão e a produção de significado: fica-se sem ter o que falar ou mostrar, sem o que discernir, sem o que defender. Portanto, já que o que uma versão afirma ou que uma visão mostra jamais pode ser diretamente cotejado com o real absoluto e isento de interpretação, resta apenas a possibilidade de analisar as relações internas a cada versão e visão que lhes permitem fazer referência a um mundo e o modo como se dá o encaixe entre diferentes versões. Não obstante, diz Goodman, é obscuro como versões e visões de mundo tão diversas poderiam atender ao requisito da redutibilidade ou mesmo à condição da intertradutibilidade:

Aqui não temos um conjunto organizado de sistemas de referência, nenhuma regra evidente para transformar física, biologia e psicologia umas nas outras, e absolutamente nenhum meio de transformar qualquer uma delas na visão de Van Gogh, ou a de Van Gogh na de Canaletto. (...) de descrever ou de representar pictoricamente 'o mundo' nós nos voltamos às descrições e representações, mas sem nem mesmo a consolação da intertradutibilidade ou qualquer organização evidente dos diversos sistemas em questão (Goodman, 1978, p. 3).

Além disso, complementa lembrando que "as muitas versões de mundo diferentes são de interesse e importância independentes, sem qualquer exigência ou presunção de redutibilidade a uma base única" (Goodman, 1978, p. 4). Atente-se para o significado aqui conferido por ele ao termo "base": o sentido pode ser aproximado ao 
do conceito matemático de uma base que é escolhida para gerar todos $e$ apenas os elementos de um espaço vetorial. Neste contexto, um vetor que não é gerado pela base não existe naquele espaço vetorial. Em suma, como resultado de suas observações emerge a conclusão de serem vãs todas as tentativas de conceber a realidade enquanto tal de um modo determinado, ou mesmo a crença na possibilidade da montagem de uma representação capaz de ordenar a multiplicidade de aspectos que podem ser objeto de nossas experiências em uma formalização unificada à qual cada um desses aspectos se amolde. É uma atitude mais fértil, portanto, dirigir a atenção para o que se tem de concreto: as versões em si mesmas e o seu modo de funcionamento.

\section{Confeccionando mundos}

A enorme resistência experimentada em relação à idéia de uma realidade que se desvanece no exato instante em que se faz um movimento para apreendê-la é, assim, resultado de um elaborado processo de entrincheiramento. A familiaridade com que o ser humano tende a enxergar o mundo é um traço que permeia todos os planos de sua atividade. Além disso, o modo que cada um de nós tem de perceber, de se dar conta do mundo, natural ou humano, decorre da predisposição a notar traços que se encaixam a determinados interesses a que nos filiamos. O físico Max Born observa que

para a maioria das pessoas as coisas reais são aquelas importantes para elas. A realidade de um artista ou de um poeta não se compara à realidade de um santo ou de um profeta, nem à realidade de um empresário ou de um administrador, de um filósofo natural ou de um cientista (citado por Cole, p. 96).

Este comentário de Born traz à tona o vínculo entre realidade e produção de significado. O papel de cada indivíduo na confecção do mundo no qual interage é, portanto, uma tarefa que lhe incumbe diretamente, uma condição da qual não pode se demitir. A dependência crucial que a percepção sensorial demonstra ter em relação à aplicação de conceitos é um exemplo nítido do grau em que o ser humano se acha comprometido a ocupar uma posição ativa na construção da sua realidade. É bem conhecido que o repertório de elementos fenomênicos que a percepção de alguém é 
capaz de apreender corresponde aos aspectos perceptivos que se conformam às expectativas, hábitos e valores do indivíduo e das práticas humanas compartilhadas em que ele se insere. Estes conteúdos de experiência definem as distinções de significados que se está apto a fazer. É possível citar inúmeras situações que oferecem demonstrações dramáticas dessa dependência, encontradas desde as percepções corriqueiras que orientam nossas ações no dia-a-dia até episódios registrados na história. Tome-se, por exemplo, o caso das observações por telescópio que o holandês Christian Huygens realizou do planeta Saturno no século XVII, e que lhe serviram de ponto de partida para a confecção de uma série de desenhos minuciosos (Cole, p. 87). Nestes desenhos, no entanto, os anéis do planeta não foram registrados - apesar de o instrumento oferecer condições para isso - o que se justifica em razão de que aquelas estruturas eram totalmente inesperadas para as expectativas da astronomia naquele momento. O inverso se deu com Galileu em sua defesa do sistema de mundo copernicano, apoiada, entre outros argumentos, em observações por telescópio de luas na órbita de Júpiter. Entretanto, as autoridades a quem Galileu insistiu em fazer ver as luas não puderam vencer suas concepções fortemente presas à interpretação teológica geocêntrica do mundo. Casos como estes aguçam a compreensão do fato de que os modos de organização e interpretação da realidade dependem não mais daquilo que é encontrado nesse mundo que daquilo que nele é inserido. Nesta categoria, situam-se valores, hábitos, interesses, expectativas, normas e conceitos.

\subsection{A confecção de mundos pelas artes e ciências}

Partindo de outros postulados, a localização dos processos de construção de artefatos intelectuais no centro da esfera do conhecimento é também a ilação alcançada por Jacob Bronowski. Ele chama atenção para a ruptura que representa - no desenvolvimento filogenético do ser humano tanto quanto no ontogenético - a emergência do símbolo e a aquisição da capacidade mental de realizar operações simbólicas. O símbolo é o instrumento com o qual os seres humanos, até então restritos àquilo que está circunstancialmente presente para os sentidos, tornam-se capazes de

operar mentalmente com entidades ausentes no tempo e no espaço. Ao emergir o símbolo na história do desenvolvimento da espécie ou de uma criança, surge assim com ele a possibilidade de liberação em relação ao imediato da experiência sensorial. A 
simbolização descortina ao ser humano o território da liberdade, e a potencialidade de realizar explorações nesse novo território vem a ser exatamente o traço que o diferencia do animal:

É verdade que às vezes agimos movidos pela necessidade, como os animais. Mas podemos nos reconhecer como homens quando nossas ações são praticadas em liberdade: quando as crianças brincam, quando os jovens encontram prazer no pensamento abstrato, quando precisamos sopesar duas ambições e escolher entre elas. Esses são atos humanos, belos como uma pintura ou uma invenção, porque neles a mente se projeta livre e exuberante. (...) porque não é a coisa feita que é bela, mas o ato de fazê-la. Se apreciamos uma coisa é porque revivemos a estimulante liberdade de fazê-la (Bronowski, p. 57).

Esta liberdade é fruída na participação. Tomando parte em inúmeras situações comunicativas ligadas a esforços propositados, os seres humanos testam arranjos e rearranjos de símbolos, de maneira a um só tempo ilimitada e coerente com propósitos peculiares a determinadas práticas. Com base no desempenho destas configurações simbólicas em situações variadas, e para finalidades diversas, por um lado, aprendem a compreender e a manipular as consequiências de ações e do uso de palavras e, por outro, em sua mente, concebem idéias e imagens. Essas imagens são a matéria-prima para a atividade de imaginação. O que Bronowski designa por imaginação está, dessa forma, longe de se confundir com o preconceito comum de uma projeção irresponsável a um domínio irreal e desconexo de idéias, ou mesmo de algo que possa ser mais ou menos identificado com a recordação. $\mathrm{O}$ sentido que busca está próximo ao que se pode depreender neste depoimento de Einstein:

As palavras ou a língua, escrita ou falada, parecem não ter função alguma no mecanismo do meu pensamento. As entidades psíquicas servindo como elementos no meu pensamento, são certos signos ou imagens mais ou menos claros, que podem ser reproduzidos e recombinados intencionalmente. Naturalmente, há certa conexão entre esses elementos e conceitos lógicos relevantes. É claro, também, que o desejo de alcançar conceitos logicamente 
interligados constitui a base emocional desse jogo bastante livre com os elementos acima mencionados. Contudo, do ponto de vista psicológico, esses jogos combinatórios parecem constituir o aspecto essencial do pensamento produtivo - antes que surja alguma ligação com construções lógicas verbais, ou outra espécie de signos que possam ser comunicados a outros ${ }^{3}$.

As imagens referidas por Bronowski são, portanto, resultado da apreensão sinóptica, imediata e criativa de símbolos articulados em um funcionamento determinado, embora, muitas vezes, não redutível a um raciocínio proposicional. No sentido dado por ele, imagens correspondem ao que se poderia referir como "modos de ver com a cabeça", podendo ou não ter um caráter visual. Aqui, ver é o mesmo que produzir significado. Em adição, deve ser observado que, se um significado específico surge, isto ocorre apenas porque a manipulação inventiva de símbolos é como se fosse uma experiência vivida na mente de cada sujeito. A imaginação não é uma habilidade abstrata, formal e invariante sob mudanças em seu conteúdo: para ser exercitada e adquirir uma forma, precisa estar conectada a conteúdos imagéticos específicos. Ela é, assim se poderia dizer, uma simulação mental de uma experiência virtual, e que parte como qualquer experiência - da reunião de outras anteriores ou simultâneas a ela. A este respeito, o mais importante não é definir o que a experiência é em termos de estados mentais internos, mas o modo como ela funciona como parte relevante de uma atividade, ou seja, o que dela e com ela se faz no âmbito de uma prática compartilhada. Esta última é o que torna acessível e compartilhável a experiência interna do sujeito, e o que faz contínuos os seus aspectos subjetivo e objetivo. No andamento das atividades desenvolvidas como parte de uma dessas práticas humanas - como a participação nos modos de apreciar uma peça de arte, ou em um esforço educativo para liberar compreensões acerca de determinado aspecto do conhecimento científico do mundo os indivíduos são engajados na construção de relações a partir de ingredientes de ações, falas, objetos e acontecimentos, e que têm como meta a realização de determinados propósitos da prática em questão. A princípio, todos os participantes têm condições de discernir claramente as conseqüências que as relações concretizadas acarretam no tocante à efetivação ou à frustração daqueles propósitos. Logo, a possibilidade de

\footnotetext{
${ }^{3}$ Extraído da obra de Brewster Ghiselin, The Creative Process, NY: Mentor Books, 1952, p. 43. Citado por OSTROWER, 2007, p. 34.
} 
perceber e de comunicar tais efeitos entre os participantes da atividade irá modelar a experiência subjetiva de cada um deles. O elemento subjetivo não deve, pois, ser sempre entendido como aquilo que é inacessível e arbitrário, mas neste caso como algo que é sintetizado na experiência particular para ir a caminho de uma regra válida no domínio de uma atividade comum.

Portanto, a imaginação, segundo Bronowski a caracteriza, trata-se da atividade de manipular e transformar imagens mentais, realizando associações, ordenamentos, diferenciações dessas imagens. Nessa perspectiva, versões e seus respectivos mundos são construídos mediante operações complexas com símbolos, em que o ser humano é movido por seu próprio impulso básico de liberdade. Não só as artes, mas também as ciências passam, assim, a poder ser compreendidas como frutos da habilidade caracteristicamente humana de realizar a atividade autônoma - quer dizer, automotivada, auto-impelida - de manipular símbolos, visando à ampliação da sua liberdade. É ofício de artistas e cientistas - bem como de professores - produzir mediações entre pessoas e pessoas e entre pessoas e o mundo, por meio de arranjos de elementos de experiências diversas, a fim de agarrar e compartilhar aquilo que se encontra fora do alcance da percepção imediata. Todos esses agentes vão inteiros para o seu próprio trabalho, carregando para dentro dele um cabedal de experiências; sem elas, ficariam impedidos de qualquer ação, em silêncio e imóveis, uma vez que estariam totalmente privados de conteúdos. Conclui-se, assim, que nas ciências tanto quanto nas artes, subjetivo e objetivo são momentos que se alternam e se continuam, atuando como aliados e não como antagonistas. Em operação, existem mecanismos de retroalimentação que avaliam o resultado desta ou daquela possibilidade de escolha, deste ou daquele ajuste ou modo de arranjo de símbolos e de experiências.

Bronowski oferece um exemplo da atuação construtiva da imaginação na apreciação de um poema. Ao abordar o problema da verdade do conhecimento na poesia, Bronowski levanta a seguinte questão (Bronowski, p. 19): "Como explicar que o poema possa transmitir essas verdades profundas diretamente do poeta para o leitor, por assim dizer, integralmente? Que acontece com a literatura que torna possível a comunicação não só do prazer, mas também do conhecimento?" A chave, aponta ele, se encontra em um dos aspectos da liberdade que a imaginação confere ao ser humano: idéias pertencem, em parte, à experiência coletiva e, em parte, à subjetividade e, sendo assim, cada sujeito tem algum grau de autonomia para imprimir uma direção peculiar para a associação imaginativa dessas idéias, um acabamento pessoal para a organização 
da trama simbólica com que recobre os estímulos que lhe chegam da exterioridade. $\mathrm{O}$ poema é um símbolo que funciona fornecendo uma série não completamente determinada de imagens que cabe ao leitor terminar de concretizar. Com ele, o leitor participa de uma situação simulada, construindo relações entre experiências ou entre séries de imagens, relações que lhe permitem discernir aquilo que ele não via até então. As imagens do poema aderem ao conjunto de experiências e significados existenciais de cada sujeito e, com o seu concurso, alcançam o resultado de refletir de volta para ele as mesmas experiências sob uma nova luz. Elas ganham, desse modo, a possibilidade de serem representadas pelo sujeito de uma forma inovadora e iluminadora, em última análise, autêntica. "Isto é o que eu me digo por meio do poema", resume Bronowski, ao fazer sua interpretação de uma poesia de Dylan Thomas (p. 31). Neste sentido, o movimento em que se constitui a verdade que um bom poema carrega serve de modelo para como deve ser um processo bem sucedido de mediação no terreno da educação em ciências.

O poema é, portanto, um meio de produzir ordem nas experiências do apreciador, pois favorece que relações entre suas próprias experiências e as de outrem sejam por ele consumadas, propiciando-lhe a habilidade para fazer certas discriminações de significados em percepção. Tais discriminações carregam conhecimento na medida em que estão alicerçadas em significados passíveis de ser compartilhados e comunicados entre pessoas a partir de sua participação em uma família de experiências diretas e transmitidas; é bom que se diga, ainda: esses significados são desenvolvidos e aprofundados quando pessoas se engajam em grupo na prática de interpretação de poemas e interagem em função de levar essa prática partilhada para diante. Nesse processo, experiências, eventos e observações entre os quais não se haveria de supor nenhuma ligação sofrem uma reorganização que os entrelaça a todos em função de significados próprios ao indivíduo que participa da concreção do poema. Quer se trate de um poema ou de um teorema, a presença constitutiva da imaginação no ato de criação dessas peças de conhecimento subunidades inseridas em versões de mundo - põe em evidência a necessária participação do sujeito em sua reconstrução. A fim de que essas peças ganhem sentido e passem a figurar na realidade, Bronowski salienta a obrigatoriedade de que o sujeito dê sua própria contribuição: refazendo os passos da formalização do teorema ou poema, explorando sua estrutura interna e situando tudo isso em relação a sua própria experiência, de modo a revesti-los de um significado pessoal que ultrapassa a simples 
repetição - e instrumentalização, no caso do teorema. Em última análise, o conhecimento é resultado de totalidades formadas por pessoas e configurações simbólicas atuando de maneira solidária e concatenada aos propósitos de uma atividade específica. Estas totalidades constituem mundos em cujos contextos é possível agir em conjunto com outras pessoas e estabelecer com elas trocas comunicativas.

Assim, esta habilidade de compreender com símbolos é de enorme relevância não apenas na apreciação de uma obra de arte. O mesmo fenômeno - de por meio de uma reconfiguração de regras para associação de conceitos e idéias, tornar-se apto a enxergar com nitidez nexos existentes entre itens que até ali se encontravam embaralhados - pode ser observado em todas as projeções imaginativas que tomam parte nos processos de criação e recriação do conhecimento científico. Isto está patente no relato de inúmeros cientistas, entre eles o físico austríaco Victor Weisskopf:

Os eventos se apresentam de modo nebuloso e, de repente, você vê um nexo. Ele exprime um complexo de interesses humanos que lhe toca fundo, que associa coisas que sempre estiveram dentro de você, mas que nunca antes haviam sido colocadas juntas (citado por Cole, p. 111)

A livre manipulação de entidades ausentes por meio de símbolos permite, ainda, que o ser humano projete diante de si (e se projete em) situações que ele não experienciou, ou mesmo que ele não poderia jamais ter experienciado, e que ainda assim são inteligíveis. Sendo assim, produzir uma constelação de símbolos tem como critério de sucesso - ou, caso se prefira, como critério de "verdade" - ir ao encontro de uma projeção eficaz. Quando bem sucedida - i.é, verdadeira, em um sentido amplo do termo - a constelação simbólica lança diante do sujeito que a manipula um nexo, ao mesmo tempo inesperado e convincente, que experiências heterogêneas adquirem ao serem integradas em um determinado arranjo sistêmico. $\mathrm{O}$ alcance e a extensão desta eficácia de projeção são avaliados pelo grau de clareza e de iluminação da totalidade que, por intermédio do símbolo, o sujeito poderá ser capaz de integrar e apreciar. Também é por meio de projeções imaginativas que ações virtuais distintas podem ser divisadas e testadas pela comparação dos seus possíveis efeitos, julgados por sua adequação aos padrões e interesses de uma prática correspondente. Operações desta natureza são exatamente as que se encontram na base da criação artística assim como da solução de problemas na ciência. 
Em suma, a ciência, tanto quanto a arte, ou a percepção, se baseia na capacidade humana de usar símbolos para tornar presente em experiências aquilo que está ausente para os sentidos, de modo a habilitar o ser humano a se situar em circunstâncias hipotéticas. Nas palavras de Bronowski:

Os símbolos usados nessa equação fundamental do século $\mathrm{XX}\left[\mathrm{E}=\mathrm{mc}^{2}\right]$ são imagens que representam objetos ausentes, ou conceitos, exatamente o que acontece com as palavras "árvore" ou "amor" em um poema. O poeta John Keats não escreveu nada fundamentalmente diferente de uma equação quando escreveu que "a beleza é a verdade, e vice-versa, e isto é tudo o que sabemos e tudo o que precisamos saber". Não há qualquer diferença entre o emprego de palavras como "beleza" e "verdade" no poema e de símbolos como "energia" e "massa" em uma equação (Bronowski, p. 38).

Poemas e teoremas são apenas dois dos exemplares de um conjunto muito mais amplo de configurações simbólicas com a capacidade de produzir arranjos e projeções iluminadoras de itens de experiência. Estas configurações podem estar escritas - como uma sinfonia ou um artigo científico - ou serem capturadas de modo implícito - como os processos tácitos envolvidos em práticas totais como a participação de uma aula ou a manufatura de um piano Steinway - e são encontradas nas artes - como peças de teatro e espetáculos de dança - e também na ciência - como as teorias, os experimentos, as aulas e os simpósios.

\subsection{Sistemas de símbolos}

A análise coerente dos sistemas simbólicos e funções referenciais efetuada por Goodman elucida e confere generalidade ainda maior para as explicações fornecidas por Bronowski acerca do papel que a imaginação exerce na construção de fatos. Conforme visto anteriormente, para Goodman, o ser humano acha-se confinado a um mundo de cada vez ou a vários mundos simultâneos, confeccionados por versões e visões que não podem ser traduzidas umas nas outras, tampouco reduzidas a uma única versão, e que por vezes revelam-se conflitantes. Em face dessa realidade em forma de mosaico, 
Goodman identifica um elemento capaz de gerar uma abordagem geral e sistemática para dar conta da construção do conhecimento em campos tão diversos quanto as artes, as ciências e a percepção sensorial. Esse elemento é, segundo ele, o ato básico de fazer referência a um mundo mediante a aplicação de símbolos. Em sua obra Languages of Art (1976), Goodman expõe sua teoria geral dos símbolos e discute como símbolos se reúnem para formar sistemas e os diferentes modos em que estes sistemas funcionam ao fazer referência a itens de mundo. Algumas versões e visões construídas e interpretadas a partir de sistemas de símbolos são, por exemplo, obras de arte, como uma pintura, uma peça musical, uma obra literária, uma coreografia, etc., ou conjuntos desses objetos; na ciência, uma determinada teoria ou modelo teórico, um diagrama, um projeto de montagem experimental; na percepção visual, a visão da tridimensionalidade de um vaso de flores, uma combinação de conceitos de forma, ou de cor, e assim por diante. Portanto, há sistemas simbólicos de diferentes espécies: lingüísticos, com símbolos selecionados de uma língua particular, e não-lingüísticos, como os pictóricos, os matemáticos, os gestuais, entre outros.

Em uma breve caracterização, sistemas de símbolos se definem por três elementos estruturais: $i$. um esquema, i.e., uma família de caracteres que podem ser combinados em caracteres compostos segundo certas regras sintáticas; ii. um campo de referência, composto das classes de itens de mundo que são referidas por algum caractere do esquema; e, por fim, iii. as regras semânticas que estabelecem as correspondências entre os caracteres do esquema e as classes no campo de referência. Conforme sejam as regras semânticas, os sistemas de símbolos passam a funcionar em diferentes modos de referência. Três tipos básicos de modos de referência são apontados por Goodman: denotação, metáfora e exemplificação. E estes podem se achar combinados em uma mesma versão ou visão simbólica de modo a produzir exemplos de referência complexa. Todas essas características relativas aos sistemas simbólicos produzem um cenário riquíssimo pelo qual desfilam sistemas lingüísticos e nãolingüísticos, literais e metafóricos, denotacionais e exemplificacionais, representacionais e não-representacionais, a serviço da construção de mundos nas artes, nas ciências e em outros campos. Para o momento, no entanto, importa levar em consideração, especificamente, a descrição oferecida por Goodman de procedimentos envolvidos na atividade de construção de mundos, em cada área do saber, pela imposição de regras de sistemas de símbolos. 
Goodman enfatiza alguns desses modos de confecção de mundos. Mundos se constroem, de acordo com ele, como resultado do ato deliberado e bastante arbitrário de lançar mão de procedimentos de construção em acordo com as regras de determinados sistemas de símbolos, a fim de obter uma interpretação particular da realidade. Esses sistemas de símbolos não surgem do nada, mas são produzidos a partir de transformações de sistemas de símbolos previamente existentes, transformações que alteram a estrutura anteriormente mencionada. Fica claro que a imposição é codificada pela força do hábito, e que os mesmos procedimentos gerais de construção estão presentes nas artes assim como nas ciências e na percepção (Goodman, 1978, pp. 7-17). A saber: $i$. composição e decomposição: trata-se da divisão de um todo em partes componentes, como na análise de tipos em subtipos que indicam diferenciações, ou, no sentido oposto, a fusão em uma mesma categoria, ou sistema, de elementos que no princípio eram tidos como desconexos. Os símbolos gerados por decomposição são cruciais aos atos de identificação, nos quais se reconhece um objeto como sendo de um tipo determinado. São importantes ainda para a finalidade de realizar verificações de permanência ou de transformação no estado de algo que esteja sendo observado; $i$. a ponderação envolve a aplicação de ênfases, ou acentuações, ou valorações diferentes a categorias classificatórias distintas, de maneira a definir hierarquias de tipos de categorização mais e menos relevantes a serem utilizados na avaliação ou análise de um objeto. Goodman oferece um exemplo desse procedimento nas artes:

Muitas das diferenças entre retratos de Daumier, Ingres, Michelangelo e Rouault são diferenças nos aspectos acentuados. O que conta como ênfase, evidentemente, é se afastar dos graus relativos de proeminência estabelecidos para as várias características no mundo que nossas formas cotidianas de ver estão correntemente constituindo. Com a variação nos interesses e novos insights, o modo de ponderação visual de características de volume, ou de linha, ou de ponto de vista, ou de luz se altera, e o mundo que ontem era razoável parece deturpado de uma maneira estranha - a paisagem de calendário que até ontem era realista agora se torna uma caricatura repulsiva (Goodman, 1978, p. 11).

iii. ordenação, tal como ocorre na percepção de gradações: por exemplo, de cores mais opacas para as mais brilhantes, de tons mais claros e mais escuros; de sons mais agudos 
e mais graves, mais intensos e mais fracos; de humores, do triste ao alegre, do tranqüilo ao febricitante; ao discernir seqüências, como de notas musicais numa seqüência temporal, ou em compassos, ou numa escala de oito ou de doze tons; ao estabelecer uma ordem ou sentido, como a ordem em que as palavras escritas em um livro devem ser lidas, ou em que as notas em uma partitura devem ser executadas; na periodização histórica em décadas, séculos ou eras, etc.; $i v$. supressão e suplementação, em que ora se realizam preenchimentos - como na interpolação de dados experimentais por curvas suaves; como quando um pianista interpreta uma peça registrada em uma partitura; ao atribuir significado a uma figura da qual está faltando uma parte, perceber uma superfície bidimensional como uma face de um objeto em três dimensões - e ora se fazem cortes, como ao estar distraído e não perceber o som de uma campainha, prestar atenção a uma das vozes de uma fuga em detrimento das outras, ou quando um cientista faz idealizações, ao impor um formato esférico para a terra, desprezar os efeitos do atrito ou da resistência do ar em um movimento; v. distorção, i.e., deformações ou reestruturações na forma de algo, seja numa paródia, ou na variação em torno de um tema musical, ou ainda em compor a imagem de uma figura impossível - como um triângulo com três ângulos retos - a partir de uma sugestão especialmente arranjada para isso.

Por meio destes e de outros tipos de procedimentos, mundos novos vão surgindo a partir da reformulação de mundos mais velhos. Eles estruturam sistemas de representação e descrição, exemplificam atributos, nuances e aspectos a que um objeto oferece suporte, transferem sentidos e ações de um domínio de experiência para outro. Ao serem utilizados, acabam influenciando as respostas que se dão a perguntas como:

- “Isto é ou não a mesma coisa que aquilo?”;

- "Houve mudança ou constância?";

- “Existe um padrão nesta coleção de itens?";

- “Isto vale mais ou menos que aquilo?";

- “Quais e quantos elementos pertencem a esta classe?”;

- "O que se pode perceber neste acontecimento?";

• “Há ou não relação entre essas observações?";

- “Aconteceu ou não?”;

- “Isto vem antes ou depois daquilo?". 
Não é à toa que os mesmos procedimentos se fazem presentes também na manipulação pessoal de sistemas simbólicos ligada à reconstrução de múltiplos mundos por um sujeito engajado em um esforço de compreensão. Fazer uma apreciação bemsucedida de uma obra de arte, compreender a estrutura de um teorema, de um conceito científico ou filosófico, perceber um determinado movimento, som, imagem, gosto, etc., ou reconhecer as diferentes facetas de um mesmo objeto certamente passa pela aprendizagem desses procedimentos por um sujeito e o seu empenho em combiná-los de modo ativo em uma determinada ordem.

\section{$4 \quad$ Veracidade e outros padrões de correção}

Até aqui, observou-se a necessária interveniência de sistemas de símbolos a fim de instituir versões e visões particulares construídas mediante procedimentos como os exemplificados anteriormente e com as quais se pode, então, fazer referência a, ou ter experiências de uma pluralidade de mundos. Em virtude do hábito criado a partir da aplicação altamente bem sucedida de uma versão específica para se orientar no mundo do dia-a-dia, o ser humano tem a tendência a formular questões do seguinte tipo: qual das visões é a verdadeira, ou a real: aquela constituída a partir da gramática perceptual objetiva que regula a apreensão do espaço no quadro "Casamento de uma virgem", de Raffaello, baseada na concepção de um espaço absoluto, de um ponto de vista privilegiado para evidenciar um acontecimento; ou a apresentada em um quadro cubista ou futurista, que tematiza a perda da coerência na composição de uma imagem a partir dos diferentes ângulos de uma mesma situação, ou dos diferentes instantes na evolução temporal de um objeto em movimento, arranjados de modo adjunto? Depois de colecionar inúmeras observações como esta, convence-se de que assumir a existência de um mundo implica obrigatoriamente em assumir a existência de mundos múltiplos.

A segunda alternativa é partir em busca da conciliação dos conflitos existentes entre as diversas versões (Goodman, 1978, pp. 109-120). Tão logo se tenha conseguido levar a conciliação a efeito se observa, no entanto, uma conseqüência inesperada e até certo ponto frustrante. Em muitos casos, a conciliação somente pode ser feita por considerar que está implícito que as proposições (ou representações, ou exemplificações, não-lingüísticas) feitas a partir de cada versão são verdadeiras 
(corretas) apenas em relação a cada uma destas, e que as diferenças existentes não estão presentes no mundo, mas consistem em diferenças entre convenções distintas. Percebese, então, que ao tentar compor um mundo único, termina-se sacrificando todos, com a perda de toda concepção determinada do real. É esta a situação em que se encontram as artes, as ciências, a percepção, conclui Goodman. Diante desta relatividade, brota de maneira justa e natural a dúvida: se todo o conhecimento do ser humano é fruto de convenções, qualquer versão ou visão que possam ser confeccionadas mediante os procedimentos já mencionados devem ser admitidas como válidas? Será preciso encarar a perspectiva de um relativismo radical nas transações cognitivas do ser humano com o mundo? O que sobrará do senso comum perante uma posição que parece pulverizar a comunidade num amontoado de células individuais e incomunicáveis? "Com toda essa liberdade para dividir e combinar, enfatizar, ordenar, suprimir, inserir e cortar, e até mesmo distorcer, quais são os objetivos e as restrições? Quais são os critérios de sucesso em construir um mundo?" (Goodman, 1978, p.17). Eis a resposta de Goodman (1978, p. 94):

\begin{abstract}
A boa vontade em aceitar incontáveis versões alternativas verdadeiras ou corretas não significa que tudo vale, (...) que verdades não são mais distinguidas de falsidades, mas apenas que a verdade deve ser concebida de uma forma diferente de como sendo correspondência com um mundo pré-moldado. Embora construamos mundos fazendo versões, não fazemos mundos reunindo símbolos ao acaso assim como um carpinteiro não faz uma cadeira juntando pedaços de madeira aleatoriamente.
\end{abstract}

Não se admite o laissez-faire: nenhuma versão relevante pode ser construída de improviso ou de maneira precária. Para Goodman, tudo que a condição de contar com múltiplas versões e visões conflitantes admissíveis sinaliza nada mais é que a insuficiência ou estreiteza da noção de verdade, e a necessidade de reexaminar essa noção a ponto de contemplar padrões abrangentes de correção. Por um lado, versões lingüísticas, descritivas e que contém proposições, como nas ciências, contribuem não mais para a confecção de mundos que visões não-denotativas, não-representacionais, que não fazem afirmações - e que, portanto, não possuem valor de verdade, não podem ser deduzidas logicamente - mas que exemplificam ou expressam vigorosamente atributos de cor, forma, textura, etc. que, de outro modo, permaneceriam inertes, 
inoperantes. É da operacionalização desses atributos exemplificáveis que se incumbem muitas obras de arte - do mesmo modo que da operacionalização das variáveis do mundo físico se incumbem as teorias e os experimentos da física. Por outro lado, mesmo para a averiguação do sucesso de uma versão ou visão a que se aplique o valor de verdade, este critério está longe de ser suficiente (1978, pp. 120-1):

\begin{abstract}
Algumas verdades são triviais, irrelevantes, ininteligíveis, ou redundantes; amplas demais, estreitas demais, excessivamente maçantes, bizarras ou complicadas; ou tiradas de alguma outra versão que não aquela relevante ao contexto em questão, como quando um guarda, tendo recebido ordem para atirar em qualquer de seus prisioneiros que se movesse, imediatamente atirou neles todos explicando que eles se moviam rapidamente em torno do eixo da terra e em torno do sol. (...)

Não só pode a escolha muitas vezes ser de uma afirmação que é a mais aproximadamente correta em outros respeitos em relação a uma que é a mais aproximadamente verdadeira, como nos casos em que a verdade é restritiva demais, muito irregular ou não se ajusta confortavelmente a outros princípios, podemos escolher a mentira mais próxima que seja obediente e iluminadora. A maior parte das leis científicas é desse tipo: não relatos disciplinados de dados detalhados, senão simplificações Procusteanas abrangentes.
\end{abstract}

Assim, as artes, as ciências, a percepção proporcionam, de fato, convenções de aplicabilidade limitada a determinado mundo: versões e visões de mundo que não são redutíveis a uma única, nem sequer intertradutíveis. Porém, tais versões e visões serão admissíveis na medida em que forem corretas:

Sob correção eu incluo, junto com a verdade, padrões de aceitabilidade que algumas vezes suplementam ou mesmo competem com a verdade onde ela se aplica, ou substituem a verdade para versões [renderings] não-declarativas (Goodman, 1978, p. 110). 
Uma pista para a natureza dos padrões com os quais a correção de versões e visões diversificadas pode ser aferida é sugerida por Bronowski, ao expor com clareza o problema: "Não é verdade que uma teoria científica precisa ser verdadeira, enquanto uma obra de arte pode estar distante da verdade?" Em face dele, o próprio Bronowski esboça a seguinte resposta:

A resposta gira em torno da questão do sentido que atribuímos à palavra "verdade" (...) (Bronowski, p.50). (...)

Tudo o que é criado, tanto na ciência como na arte, é uma extensão da nossa experiência para novos campos. Todas essas criações precisam ajustar-se tanto à experiência comum da humanidade como às experiências particulares de cada pessoa. A obra científica ou literária afeta-nos profundamente, no campo mental e emocional, sempre que corresponde à nossa experiência e ao mesmo tempo se projeta mais longe. Esse é o sentido de "verdade" compartilhado pela arte e pela ciência, mais importante que as diferenças de conteúdo factual que dividem os dois campos (p. 51). [meus grifos]

Para que uma versão venha a adquirir eficácia de construção e de compreensão de mundo, ela deve atender a requisitos que favoreçam sua relevância, inteligibilidade e credibilidade. Para Bronowski, como também para Goodman, correção é uma questão de ajustamento. Uma versão ou visão correta exibe um determinado ritmo que, segundo John Dewey, define um padrão recorrente para o modo como as experiências se movimentam: as experiências que a humanidade assimila em diferentes circunstâncias e com diferentes finalidades vão sendo trançadas em tapeçarias e, com isso, lentamente modificam os desenhos dos sistemas de símbolos que se estampam em sua superfície e que são utilizados pelo homem para se dirigir no mundo e dirigir o curso de suas atividades. Por sua vez, as novas estampas simbólicas interferem na continuidade do processo de urdidura de experiências. Trata-se de um processo de ajustamento entre continuidade e transformação: a continuidade entre diferentes partes da tapeçaria, que se compreende ao ver que os fios dos quais cada uma é formada remontam a outras partes; e a transformação na compreensão do que cada fio é, ocorrida ao notar que, vindos de partes diferentes em sentidos aparentemente aleatórios, eles podem ser tramados completando uma parte da tapeçaria em um formato fechado, no qual se percebe o 
cumprimento de um propósito da prática de tramar. Note-se que Bronowski, em relação ao ajuste entre as criações artísticas e científicas e as experiências humanas, utiliza o verbo "precisam", indicando que o ajuste pode inicialmente não existir. De fato, esse ajuste não é decretado nem existe por si mesmo, previamente a uma construção: para que ele venha a se constituir devem ser postos em marcha processos de construção, simbólicos e imaginativos, de diferentes tipos ao longo da formação da cultura, da discussão teórica e prática, da educação e das interações sociais. Os artífices ou, conforme Goodman os chama, os "carpinteiros" que se esforçam em diferentes empreendimentos humanos vão aos poucos desenvolvendo modos de construir móveis com melhor acabamento e mais bem adaptados às diferentes necessidades de seus clientes, fazendo uso de novos materiais e de ferramentas e técnicas mais poderosas. Sempre é necessário provar uma sabedoria de operação com os meios, uma proficiência em ajustar técnicas a conteúdos e a propósitos. Somente assim se pode ter sucesso em produzir visões claras e profundas de domínios anteriormente obscuros. Além disso, Bronowski faz questão de lembrar que, mesmo na ciência, o ajuste nunca é total nem definitivo. Trata-se de um ajuste negociado entre o substrato insondável do mundo, o que quer que seja isto, e os princípios e propósitos do ser humano em diferentes âmbitos e circunstâncias. Um legítimo acordo, em que há de se chegar a um bom termo para ambos e em que é difícil discernir quando é que termina a realidade e começa a construção. Ressalta, assim, o caráter construtivo e dinâmico do ajuste, à medida que novos domínios passam a ser explorados. Esse ajuste se manifesta de modos diferentes em versões que servem a propósitos diferentes. Conforme a situação, ele assume formas distintas como economia de meios, facilidade de uso, muitos níveis de significado, boa formação, encaixe a um objeto de estudo, ajuste entre meios e fins, unidade, concordância com outras versões do mesmo tipo, inovação, surpresa, novidade, revelação, reconfiguração de velhas experiências, etc.

Por último, que haja "diferenças de conteúdo factual" somente quer dizer que os fatos das artes são distintos dos da ciência, mas não que deixam de ser fatos, ainda que sejam tomados como tais dentro de um quadro de conceitos, valores e propósitos específico. Fatos são sempre artefatos: o importante é que o esquema em questão seja certificado por padrões rigorosos de correção.

Goodman chama a atenção a respeito de crenças pétreas universais e preceitos particulares a uma dada versão que, em determinado momento, estão em vigor estabelecendo marcos que balizam as avaliações da correção de versões e visões de 
mundo (1978, pp. 17-19 e 138-139). Em resumo, uma parte da correção de uma versão de mundo vem de sua conformidade com essas linhas orientadoras, estabelecidas por uma tradição que se transforma conforme os encontros e os testes que vão se sucedendo em seu caminho. Entre as crenças solidamente estabelecidas, situa reflexões permanentes sobre leis da lógica, reflexões passageiras sobre observações recentes, os preconceitos e as convicções de caráter universal enraizados com mais ou menos firmeza. Quanto aos preceitos internos, refere-se, por exemplo, à escolha de um referencial entre várias alternativas, à seleção de uma base axiomática e de certas categorias organizadoras, a decisões de realçar tal ou qual traço ou aspecto, e a distinções do que é e do que não é relevante para concretizar determinados propósitos em vista. Chama atenção sua observação de que a linha entre preceitos internos e crenças universais é fluida: o sucesso manifesto por uma versão pode surtir o efeito de estender suas normas internas em exigências gerais a serem levadas em conta nas avaliações que a partir de então sejam feitas de outras versões homogêneas.

Critérios múltiplos e diversificados compõem o quadro com o qual é julgado o sucesso que se obtém na aplicação de versões a mundos. Devem ser objeto dessa avaliação, por exemplo, a relevância da aplicação da versão ou visão, conforme seja, a um domínio específico; o seu poder de persuasão; suas características de abrangência e de como demonstra ser mais ou menos compacta; seus encaixes com outras versões. Todos estes fatores, em última análise, somam-se para dotar a versão ou a visão de mundo de um determinado poder de revelação. Reciprocamente, esses padrões de correção tornam a ser redefinidos em função do sucesso obtido por versões e visões na sua aplicação aos respectivos mundos.

\section{A lição epistemológica da mecânica quântica}

Dentro de um mesmo mundo, pode-se deparar com a necessidade de conciliação de duas ou mais descrições ou representações contraditórias. E se elas demonstram ser igualmente adequadas e necessárias, conciliá-las e ao mesmo tempo considerar que elas incidem em um único e mesmo mundo é um intento que só pode ser realizado tomandoas na qualidade de convenções distintas. No sentido que Goodman confere a essas convenções, é preciso insistir, elas não significam abrir portas para admitir qualquer tipo de construção, mesmo as mais frágeis, com igualdade de direitos: elas devem ser 
submetidas ao crivo de rigorosos padrões de aceitabilidade. Deve-se lembrar que, no primeiro momento, a correção de uma nova versão ou visão que desponta é avaliada pelo encaixe com mundos já estabelecidos a que elas se dirigem. Por outro lado, a prerrogativa de se movimentar, se comunicar e agir de maneira coerente e eficaz dentro de cada um desses mundos que as versões ajudam a construir é conquistada por intermédio do uso competente de determinadas versões ou visões já em vigor nos respectivos mundos. Assim, a versão ou visão recém-chegada é validada, ao mesmo tempo, pela extensão em que atinge resultados e cumpre ambições que ela própria definiu para si e por comparações de desempenho com outras versões e visões mais antigas quanto a propósitos já firmados; suas antecessoras também haviam passado por processos similares para poder se fixar.

A noção de complementaridade da mecânica quântica parece ser uma metáfora correta para conotar o sentido das explicações que Bronowski e Goodman fornecem a respeito das interações mantidas pelo ser humano com o mundo, mediadas por uma multiplicidade de versões e visões construídas por ele. Mais do que abrir caminho para que visões de características contraditórias, como as de onda e partícula, possam coexistir, o princípio da complementaridade afirma que cada uma delas é indispensável para compor um quadro completo de um fenômeno.

Conforme visto, deve ser assim com relação às versões e visões diversas produzidas pelas artes e pelas ciências. Victor Weisskopf conta uma interessante passagem que teria havido envolvendo dois dos mais influentes físicos do século XX, Werner Heisenberg e Felix Bloch (Cole, p. 115). Eles caminhavam pela praia e Bloch falava sobre novas teorias que tinham surgido para descrever a estrutura matemática do espaço. A certa altura, Heisenberg teria dito em resposta: "O espaço é azul e os passarinhos voam nele". A história é uma perfeita parábola. Em seu fundo, ela ilustra a postura filosófica que o princípio da complementaridade de Bohr carregou para dentro da teoria quântica: que a realidade de um ente é plural e só pode ser apreendida de modo completo lançando mão simultaneamente de visões não apenas distintas, mas contraditórias, sendo cada qual apropriada a um contexto e um propósito específico:

A afirmação “o espaço é azul” certamente não é uma maneira apropriada de expressar uma relação matemática - mas uma equação também seria de todo imprópria para descrever a sensação que se tem diante do céu durante uma caminhada pela praia num dia de verão (Cole, p. 118). 
O próprio autor do princípio, o físico dinamarquês Niels Bohr, declarava publicamente sua grande admiração pela pintura cubista, em particular, em virtude de esta tornar possível que um objeto seja observado de maneiras diferentes, como um rosto, um braço ou uma tigela de frutas (Cole, p. 107). A lição epistemológica de que "o que faz sentido em um contexto pode não fazer nenhum sentido em outro" (Cole, p. 115) ainda permanece longe de ter suas conseqüências plenamente apreendidas pelos próprios cientistas, e menos ainda pela cultura na contemporaneidade. As sentinelas ainda insistem em querer atirar em seus prisioneiros que desobedecem ao comando de imobilidade por se moverem em torno do eixo da Terra e em torno do sol. Na maior parte das vezes até aqui, não vimos levando em conta, como observa Goodman, que "ironicamente, nossa paixão por um mundo é satisfeita, em momentos diferentes e para propósitos diferentes, de muitas maneiras diferentes" (1978, p. 20). Nossa firme convicção em um fundamento único e independente para o mundo em que temos nossas experiências parece não ter sustentação maior que a percepção de ocuparmos o centro fixo do universo. E complementa:

\section{(...) uma afirmação é verdadeira, e uma descrição ou representação correta, para um mundo a que ela se encaixa (1978, p. 132).}

Incluam-se neste encaixe interesses, hábitos, expectativas e propósitos, a determinarem escolhas, ênfases e exclusões. Não têm o que temer, portanto, o cientista que sente desmaios em pensar que o resultado de um experimento possa ser corrompido pelo assédio da sensibilidade, ou o artista que é tomado de horror com a perspectiva de ter a expressividade de uma de suas obras aferida por medições experimentais. Por outro lado, no entanto, é um completo equívoco julgar que haja uma separação radical entre arte e ciência ou, mais amplamente, entre estética e ciência. A tendência comum a confiná-los a departamentos com características diametralmente opostas deixa-se levar antes por um preconceito construído como fruto de processos histórico-culturais na modernidade do que pelo resultado de uma análise detida e cuidadosa. As abordagens de Goodman e Bronowski, sem abrir mão de reconhecer as diferenças óbvias que marcam os dois campos, fazem justiça à filiação de ambos às mesmas classes de operações de transformação ou reconstrução com que o ser humano atua sobre sistemas 
de símbolos previamente existentes, guiado pelo impulso básico de ampliação de sua liberdade:

A diferença entre arte e ciência não é aquela entre sentimento e fato, intuição e inferência, deleite e deliberação, síntese e análise, sensação e cerebração, concretude e abstração, paixão e ação, mediaticidade e imediaticidade, ou verdade e beleza, antes, porém, uma diferença no domínio de certas características específicas de símbolos (Goodman, 1976, p. 264).

A própria objetividade é um traço do empreendimento científico que the foi imposto deliberadamente no ato de sua criação, e que acabou se consolidando em virtude de se mostrar ajustado a uma finalidade particular: propiciar ao ser humano o controle sobre os poderes da natureza. A objetividade é não mais uma consequiência do que um princípio da prática científica, fruto do esforço de apreensão da realidade mediante um método único voltado à manipulação. É preciso ter claro, no entanto, que um nível não menos elevado de correção é encontrado nas boas obras de arte e na boa percepção. Para além do que há de específico em cada campo, a correção de uma forma de conhecimento é indicada, finalmente, pelo critério do grau de reorganização do mundo costumeiro a que as versões corretas em cada um desses campos são aptas a induzir. Neste sentido, então, nem mesmo a arte abstrata pode ser excluída das formas de conhecimento, pois, como mostra Goodman (1978, p.105), é precipitado tender a vêla como se se tratasse de um universo voltado sobre si mesmo, sem nenhuma pretensão a informar a realidade:

Após termos passado uma hora em uma ou outra exibição de arte abstrata, tudo a nossa volta tende a se enquadrar em padrões geométricos ou rodar em círculos ou se entrelaçar em arabescos texturais, se resolver em branco e preto ou vibrar em novas consonâncias ou dissonâncias de cores. 


\title{
Considerações epistemológicas acerca do conteúdo da experiência estética
}

\author{
muitas das noções centrais da razão (coerência, equilíbrio, proporção, \\ completeza, simplicidade, razoabilidade) não apenas possuem conotações \\ estéticas, mas, mesmo quando definidas mecanicamente, demandam um \\ tipo de percepção estética cultivada ou de gosto para sua compreensão \\ e aplicação apropriada ${ }^{4}$. \\ Richard Shusterman
} (...) porque não é a coisa feita que é bela, mas o ato de fazê-la. Se apreciamos uma coisa é porque revivemos a estimulante liberdade de fazê-la. Jacob Bronowski

\section{De como a simbolização generalizada está relacionada a processos singulares de experienciação}

Dos argumentos de Goodman apresentados no primeiro capítulo, depreende-se que os exercícios de simbolização do ser humano se dividem em práticas especializadas de propósitos específicos complementares, mediadas por símbolos com características sistemáticas diferentes. Exclusivamente no que tange a estes propósitos específicos em direção aos quais cada prática particular se lança e procura se ajustar, esta complementaridade implica em linhas divisórias ou fronteiras que não podem ser cruzadas. As artes não estão em condições de realizar metas tais como prever cenários

\footnotetext{
${ }^{4}$ Citado por Wickman, 2006, p. 162.
} 
de mudanças climáticas, postas para as ciências, e, reciprocamente, estas não substituem aquelas em desideratos como, por exemplo, o de jogar claridade nos porões da alma humana. No entanto, em se tratando dos meios que são colocados em ação nos processos que se desenrolam nessas práticas, e no tocante às funções que ações e o uso de palavras e de outros elementos exercem dentro delas, transferências e cruzamentos são a regra. Processos de simbolização são por natureza instáveis, voláteis; objetos e eventos do mundo por si sós não definem o tipo de símbolos que sempre devem ser aplicados a eles. A pergunta a ser feita não é de que tipo o objeto é, e sim em que ocasiões ele está sendo de um determinado tipo.

Esta é a ocasião propícia para explorar em profundidade os aspectos minuciosos presentes na imagem formulada anteriormente com o fito de delinear uma visão sintética do relacionamento entre sistemas de símbolos e as experiências que brotam em atividades humanas. A imagem em questão retratava as experiências compartilhadas dos seres humanos como fios que vão sendo tramados em uma tapeçaria, ao passo que os sistemas de símbolos estariam na posição das estampas e padrões que vão se desenhando em sua superfície. Como mencionado ali, o processo da trama obedece a um padrão de movimento tal que a seqüência da urdidura concreta de experiências é influenciada pela observação dos padrões e arabescos abstratos que haviam sido previamente desenhados, e estes, por seu turno, sinalizam determinados modos de tecer que se encaminham para serem coroados com o acabamento de uma parte completa da tapeçaria. Continuidade e transformação estão em jogo à procura de se ajustarem uma à outra. Ocorrem, a um só tempo, o fluxo contínuo de fios que chegam de unidades diferentes da tapeçaria para serem tramados em uma nova unidade, e o significado transformado dos mesmos fios ao serem entrelaçados na nova unidade que é sempre um tanto diferente daquelas já completadas. Alguns sentidos contidos nesta imagem demandam ser desenvolvidos com cuidado.

Em primeiro lugar, quando um símbolo é tomado exclusivamente em relação à sua inserção dentro de um sistema, seus significados são generalizados, porém, estão desencarnados da experiência humana. O significado de um símbolo que permanece confinado à condição de redução a um sistema torna-se um pálido reflexo daqueles significados que são produzidos por uma pessoa ao participar de situações comunicativas específicas. A razão disto é que as regras do sistema de símbolos são construídas e consolidadas na continuidade e na transformação das experiências 
humanas, em contextos que - tal como os indivíduos de uma mesma família - por mais aproximados, sempre são um pouco diferenciados. O símbolo alcança a plenitude de suas potencialidades quando atua de modo solidário com seus usuários humanos. Ele possui lacunas de significado que as experiências preenchem. Isto é feito usando o símbolo em relações construídas com elementos tirados de experiências prévias e da própria situação em andamento. De outra forma, i.é, em condições de isolamento do seu uso em situações específicas, um sistema de símbolos está para a experiência humana tal qual uma gramática está para uma língua viva. Em outras palavras, o significado sistemático de um símbolo é estático, distanciado e mecânico, por oposição ao caráter processual, imediato e situado das conseqüências do mesmo símbolo em uso, relacionado à consecução dos fins de uma prática humana.

O funcionamento geral de um símbolo, fora da experiência, é um funcionamento mecânico, rígido e formal. Porém, os sistemas de símbolos são absorvidos pelas práticas humanas e vão sendo gradualmente transformados pelas funções que nelas são chamados a exercer: eles sofrem a contaminação de eventos, objetos e ações singulares que encontram em situações concretas dessas práticas, vindo a firmar relações com esses elementos. Trata-se aqui da transição de uma forma para outra que é acarretada pela interação entre o símbolo sistemático e um conteúdo determinado. Dentro das relações concretas em que são usados, os símbolos são variáveis condicionadas pelas experiências. Assim, um símbolo geral, restrito às relações mantidas dentro de um sistema simbólico abstrato, apresenta uma espécie de esboço primitivo ou matriz generalizada de significado. A partir desse esboço esquemático, à medida que processos de experiência o absorvem em seus cursos sinuosos, ele vai adquirindo significados cada vez mais complexos e acabados, em virtude das relações que segue firmando com conteúdos específicos e com outros símbolos. Sobretudo, seus sentidos são suplementados por avaliações das consequiências que as relações concretizadas têm para o prosseguimento de atividades específicas - no contexto de uma prática humana com propósitos.

Da perspectiva da outra parte deste relacionamento, i.é, as experiências em que os símbolos são levados a exercer papéis funcionais, observa-se o quanto o andamento da experiência dos participantes em direção à discriminação de um propósito do seu empreendimento depende das funções simbólicas. Os símbolos a que se refere Goodman são mecanismos para o processamento de experiências, elementos operativos 
necessários para colocá-la em movimento na rota de determinadas seleções e exclusões, distinções e similaridades com potencial de impeli-la para um fechamento consumatório. O participante da experiência necessita apreender aspectos do modo de funcionamento sistemático do símbolo a fim de adquirir aptidão para realizar plenamente, em atividades de práticas específicas, procedimentos singulares para os quais aquele símbolo é virtualmente adequado. Uma vez que tenham algum domínio destes funcionamentos sistemáticos, os que participam destas atividades poderão desenvolver modos de discernir adequados a ela e produzir significados novos conforme a atividade avança.

Este entendimento de como interagem a simbolização sistematizada e os processos singulares de experienciação irá alicerçar o desenvolvimento de uma compreensão sobre o que juízos estéticos significam e se o que eles significam importa para as atividades da educação em ciências. Entre as conclusões encontradas neste caminho, ficará firmemente estabelecida a importância de aprendizagens singulares.

\section{Relevância da singularidade no conhecimento humano}

Do ponto de vista das abordagens cognitivistas e analíticas ao conhecimento, a experiência estética seria obrigada a demonstrar o cumprimento de preceitos como os de objetividade, reprodutibilidade e generalidade para poder pleitear a condição de uma transação garantida e bem fundamentada com aspectos avaliativos de objetos e eventos. Essa expectativa seria realizada caso fosse possível ordenar e resumir toda a diversidade dos casos em que esses aspectos são avaliados por intermédio de um pequeno conjunto de regras e conceitos, ou lançar hipóteses que incorporassem princípios causais e generalizações conceituais da experiência estética, das quais pudessem ser inferidas conseqüências comparáveis com observações de ocorrências de experiência estética em condições controladas. Esses conceitos e regras serviriam em seguida para explicar o passado e orientar e fundamentar todo empreendimento futuro voltado a atribuições de qualidades estéticas a itens pertencentes a um determinado escopo, bem como para realizar previsões de situações e condições em que determinadas qualidades seriam encontradas. O domínio de aplicabilidade da teoria ou modelo teórico de estética 
continuaria se estendendo até que novos casos experimentais fossem observados que resistissem a serem abrangidos pelos princípios e regras válidos até aquele momento.

Haveria ainda a alternativa de fixar finalidades para o relacionamento estético e, a partir delas, determinar racionalmente o tipo de condutas que teriam a garantia de promover o alcance dessas metas da prática estética. No domínio da aprendizagem, esse programa teria continuidade com a introdução do quadro mentalista e representacionalista da aquisição dos conteúdos da estética, desde o qual esta aquisição seria entendida como desenvolvimento de estruturas cognitivas que mapeariam na mente as regras e conceitos esteticamente relevantes, e que governariam dali em diante o comportamento do indivíduo nos encontros com materiais em contextos especializados nos quais um intercâmbio estético devesse ser mantido. Essa visão deixaria marcas também na linguagem estética, cujos termos teriam significado em virtude de constituírem um conjunto exaustivo de rótulos para qualidades externas ou eventos mentais internos justificados por regras universais.

Partindo do entendimento de que o conhecimento deve estar alicerçado em regras universais direta ou indiretamente comparáveis com testes objetivos, os partidários das correntes de pensamento dominantes culpam a experiência estética de associação com o lado afetivo do ser humano. Afinal de contas, qualquer um sabe que, para respostas emocionais e manifestações de preferência, não se aplicam testes contra padrões externos, independentes da mente humana, como aquele que se usa para julgar a afirmação galileana de que o tempo de queda para corpos graves abandonados a partir de uma mesma altura é o mesmo a despeito do seu peso. Concluem assim que emoções não representam ou nomeiam itens independentes da própria mente, encontrados fora dela no mundo natural, mas se referem apenas a si mesmas, ou, quando muito, a estados neurológicos a serem checados por detectores de mentiras e imagens por ressonância magnética. É como se o domínio afetivo constituísse um universo autônomo e descontínuo em relação ao universo de objetos e eventos reais. O mundo natural não dá direção aos processos emocionais tanto quanto estes não determinam e não influenciam o mundo tal e qual este se dá. Em resumo, de acordo com essa versão, afetos - e, por extensão, a estética - não são regulados por um absoluto, seja ele um método empírico ou um sistema lógico, mas são arbitrariedades que em última análise derivam de veleidades humanas. 
O que parece estar em jogo aqui é o conflito entre uma abordagem analítica na base do conhecimento das ciências e uma aproximação sintética ao significado da linguagem estética. Do ponto de vista da ciência, a busca da estrutura geral tem prioridade sobre a consideração das condições particulares. Estas são incluídas em um segundo momento, como hipóteses auxiliares, a fim de obter a descrição de detalhes das situações estudadas. Voltando a Galileu, vê-se que seu feito foi transcender as influências particulares das forças resistivas sobre o movimento de queda, a fim de abraçar a lei geral do movimento acelerado de corpos sob a ação da gravidade na superfície da Terra. Com respeito às experiências humanas, a situação é a oposta: o significado sintetizado em uma ocasião singular vem primeiro; só então são desenvolvidos hábitos gerais de uso da linguagem a partir do impulso para estabelecer continuidades entre diversas situações sucessivas. O foco da ciência está colocado em proposições autocontidas, não particularmente situadas em algum contexto específico, mas cuja verdade ou falsidade pode ser universalmente garantida por padrões empíricos e/ou lógicos. Em oposição, o olhar da visão sintética se fixa sobre as totalidades que resultam da fusão de objetos, eventos, palavras e ações em atividades localizadas voltadas a certos propósitos - totalidades que produzem significados relacionais, singularmente verdadeiros e validados pelo modo como o fazer inserido na atividade conduz à consumação de propósitos. Assim, sob uma primeira inspeção, os significados da ciência parecem estar mais próximos do pólo analítico, ao passo que os da experiência estética se deslocam na direção do sintético. A questão referente à relevância da experiência estética para a ciência e para a aprendizagem de ciências é convertida, assim, no problema de verificar se as percepções de aspectos particulares que são a matéria da experiência estética - podem vir a exercer alguma função intrínseca na aprendizagem das regras e conceitos gerais da ciência.

Há, no entanto, problemas com os fundamentos da abordagem analítica. Em primeiro lugar, ela tem origem na falsa certeza de que a distinção entre cometimentos humanos repousa sobre dicotomias com direito ao estatuto de princípios universais. A divisão entre estética e ciência, por exemplo, consistiria em um fato alicerçado sobre razões que já estavam fixadas antes de estas práticas terem sido postas em marcha e ganharem materialidade pelas ações dos seres humanos. Neste sentido, a separação radical entre fato e valor, razão e afeto, realidade exterior e estados mentais internos, objetivo e subjetivo é considerada uma condição a priori sobre tudo o que a humanidade 
pode perseguir e construir. Em seguida, esta concepção prossegue com a decisão de procurar significados universalmente garantidos em palavras e proposições por si próprias, tomadas de maneira isolada como unidades completas e autônomas em relação a contextos de uso particulares. As proposições são então encaixadas de maneira unívoca em categorias distintas conforme esteja o que elas afirmam relacionado a fatos, valores ou normas. Não há, desse modo, nenhuma possibilidade de mistura entre categorias. Por fim, o papel para o qual se adapta cada uma das classes que resultam da divisão é assimilado como prerrogativa exclusiva a um determinado tipo de prática humana. Sendo assim, o discurso das ciências deve ser formulado em proposições factuais e normativas, enquanto que à estética restam os juízos avaliativos.

Entretanto, a questão do poder de convencimento exercido pelas dualidades anteriormente mencionadas liga-se a hábitos que foram se formando no decorrer de um longo processo por obra do fazer humano e que aos poucos se enraizavam em profundidades cada vez maiores no pensamento. Indo além desta fascinação por dualismos, o que se pode observar nas práticas concretas é algo diferente: quaisquer que sejam as funções que palavras e ações possam exercer, estas funções e sua carga de significação se transformam e se completam nas conexões estreitas de uma rede de eventos, ações e repercussões que são realizados, provados e reavaliados por seres humanos nos contextos de formas de vida e práticas compartilhadas. Mesmo a linguagem forjada em conformidade com distinções entre as categorias de fato e valor, ou entre qualidades externas de objetos e sentimentos internos, tampouco se exime desta observação quando colocada em uso em situações particulares. O entendimento do que uma distinção é não pode ser alcançado fora da participação em uma prática dentro da qual ela é atue e gere conseqüências. Tais dicotomias nada significam em si mesmas. Sua razão de ser e a prática em que ela desempenha uma função não podem ser desenredadas a ponto de ser possível obter uma validação do significado de uma distinção a partir de uma posição absoluta. $O$ argumento se desenvolve da maneira seguinte: entende-se a necessidade de o conhecimento científico e os saberes da experiência terem partido em roteiros distintos para que a divisão nos moldes atuais entre fato e valor ganhasse sentido; sendo assim, não é lícito tomar a distinção entre fato e valor e colocá-la de volta a serviço de produzir uma justificativa autônoma e antecipada para a separação entre ciência e experiência. Ignorar isso equivale a incorrer na falácia de utilizar, para garantir a validade da separação, a própria separação que se 
quer validar. Só se pode produzir significado para uma distinção, seja ela qual for, na medida em que apontá-la assume o papel de orientar as ações em direções que promovem a realização de propósitos de uma determinada busca ou esforço humano. Por estar situada em um ou outro tipo de empreendimento humano propositado, validar o que a distinção significa é um ato necessariamente influenciado pela observação das conseqüências que ela acarreta para a realização de certos objetivos bem específicos. Estes, por seu turno, também não são estipulados de forma antecipada, mas são os objetivos que sofrem uma diferenciação paulatina como resultado da atividade humana e que se tornam então associados a práticas especializadas. Por isso, não existe outro meio de formação e validação das distinções aludidas que não seja recorrer a experiências envolvendo trocas comunicativas entre agentes comprometidos a dar continuidade a um negócio no qual se visualizam certos propósitos. Esse fato reflete um emaranhamento irredutível entre o que está no mundo e a experiência humana. À maneira do mapa em relação a um território, a função da distinção fato/valor não é a de apontar o que é válido no terreno do conhecimento e da experiência, mas sim de interagir com esses domínios de ação, propondo formas de orientação e auxiliando a observação de certas características de relevo e o alcance de certos destinos.

Ademais, ainda que a classificação em descritivas, normativas e avaliativas seja válida para proposições consideradas como unidades autocontidas, isto não mais se justifica quando elas passam a estar integradas como partes das totalidades que as atividades humanas localizadas constituem. A perspectiva analítica não leva em conta o efeito das interações dos elementos proposicionais entre si e deles com objetos, eventos e propósitos de uma atividade situada. Por outro lado, o entendimento sintético do significado, soerguido pelo pensamento pragmatista, é de que o significado de uma palavra ou de uma sentença se funde com a atividade inteira em que se faz uso delas. Aquilo que termos, expressões e ações significam não é encontrado no isolamento da própria palavra em si ou nas proposições e ações destacadas de uma situação completa. O significado vive na inteireza de uma situação da qual palavras e ações são partes constitutivas. Ele não fica fechado em algum fragmento dela, mas está exteriorizado em uma trama extensa de relações urdida na experiência. Em outras palavras, toda experiência se constitui como um complexo indiviso que entrelaça: 1) o reconhecimento de objetos, eventos e características exteriores ao participante da experiência; 2) as emoções e os pensamentos subjetivos deste participante; e 3) significados 
compartilháveis veiculados na fala e nas ações dos indivíduos que participam da mesma experiência. A única razão que nos impede de ver isso é a maneira arraigada como as dicotomias fato/valor, razão/emoção se prendem em nossas formas costumeiras de pensamento.

A partir da perspectiva analítica cognitivista, uma forma de resolver o conflito seria obter uma descrição do relacionamento estético que o aproximasse de um cenário como o que foi delineado logo no princípio desta seção. Neste caso, a estética estaria justificada em razão de que, por detrás e na origem de suas práticas, haveria regras universalmente válidas a lhe dar sustentação. Contudo, ainda que tal redução da estética a normas e fatos bem delimitados pudesse ser materializada, pouco iria restar neste programa que fizesse lembrar o acento distinto que cada um de nós já provou ao tomar parte em experiências estéticas. Ao tentar tratar o significado de um juízo estético isolando-o de sua aplicação a uma situação específica, algo desse significado sempre é perdido. Não existe proposição universal que, ao ser aprendida, substitua e esgote o significado produzido em cada experiência singular: isto vale para cadeiras, ternos elegantes, formatos de antenas de insetos; e também para termos e qualidades estéticos. Estes itens são tão diversificados e repletos de nuances sutis que em cada novo encontro algo único é avistado que acarreta uma pequena transformação na experiência anterior. Conforme Dewey escreve sobre a experiência estética em seu ensaio "Pensamento Qualitativo" e Lenore Langsdorf ${ }^{5}$ cita:

A linguagem falha não porque o pensamento falhe, mas porque nenhum símbolo verbal pode fazer justiça à plenitude e riqueza do pensamento. (...) há algo de artificial e repelente em discursar sobre qualquer evento ou objeto consumatório. Ele fala tão completamente por si próprio que palavras são substitutas pobres (citado por Wickman, p. 32).

Assim, caso se procure desvendar fatos de estética, o primeiro a ser apontado deve ser este: a experiência estética é como uma performance de música - um processo cuja rota jamais se reproduz exatamente e cujos significados são sensíveis ao contexto e aos padrões de uso de linguagem construídos na participação dos indivíduos em uma

\footnotetext{
${ }^{5}$ LANGSDORF, L. Reconstructing the fourth dimension. A Deweyan critique of Habermas's conception of communicative action. In ABOULAFIA, M., BOOKMAN, M. \& KEMP, C. (Eds.) Habermas and pragmatism, London: Routledge, 2002, pp. 141-164.
} 
numerosa família de experiências aparentadas. É sempre bom lembrar que regras universais refletem crenças, e muitas vezes não são postuladas de princípio, e sim construídas a partir de extrapolações indutivas de casos particulares. Não é possível, pois, descolar os significados lingüísticos da experiência humana, atrelando-o exclusivamente a características objetivas. Todavia, mesmo não atendendo aos critérios cognitivistas para fatos e normas, o significado da experiência estética é ainda assim composto de normas, fatos e valores estéticos que se entrelaçam, se imbricam e são absorvidos em uma totalidade. Neste emaranhamento, desaparece a nitidez das divisões entre categorias. Fatos e valores são contínuos nas ações e na fala que as pessoas mobilizam a fim de alcançar seus objetivos durante a vida, de levar seus afazeres para diante. O estético não se reduz nem só ao interno, nem só ao externo, nem só ao empírico, ao comunicativo ou ao lógico-simbólico. Todos esses aspectos encontram-se integrados na participação em uma atividade que se desenrola em um meio social.

Seguindo o conselho dado por Wickman (p. 38), “É, portanto, razoável não iniciar uma análise do papel de experiências estéticas na educação em ciências excluindo conceitos que sem serem testados foram proclamados por certas escolas de pensamento como futilidades por natureza". O fenômeno da construção e comunicação de significados prepondera sobre a ânsia pelo real. Assim, uma abordagem mais proveitosa é partir da evidência da possibilidade de comunicação do sentido de experiências entre membros de uma prática compartilhada e observar que consequiências isso acarreta. Para estudar a experiência estética e o papel que ela assume na aprendizagem científica, é necessário preterir a visão que a retrata como fenômeno de um mundo interior inacessível em favor de outra que focaliza o seu aspecto de fenômeno comunicativo e de compartilhamento. Essas características são o que define o relacionamento estético como experiência. O mecanismo da experiência estética, segundo o pragmatismo de Dewey, e a dinâmica dos significados adquiridos por termos estéticos no decorrer de atividades propositadas são os próximos assuntos a serem visitados.

\section{Estética como experiência}

De acordo com o pensamento estético de Dewey, uma experiência é estética, ou tem conseqüências estéticas, em situações em que se cumprem duas condições: $1^{\text {a }}$ ) na 
atividade da qual uma pessoa participa em companhia de outras, os esforços feitos por elas conseguem realizar uma fusão de significados provenientes de outras experiências anteriores; e $2^{\text {a }}$ ) esses elementos de significado perdem sua distinguibilidade no todo formado, fazendo a atividade avançar em direção a um fechamento consumatório. $\mathrm{O}$ verbo "conseguir" está aí empregado intencionalmente a fim de acentuar o risco que é inerente a qualquer empreendimento, devido a possíveis desvios de curso e barreiras que muitas vezes são encontradas no caminho da experiência. Resumindo as principais linhas da posição estética de Dewey, Per-Olof Wickman irá dizer que "A experiência estética é uma parte integrante da atividade prática e está ligada a continuidade, transformação e significado. É, portanto, um sinal de participação e transformação da experiência" (Wickman, p. 71).

$\mathrm{Na}$ terminologia de Dewey, as condições aqui mencionadas, as qualidades que, juntas, distinguem uma experiência como estética, são chamadas de imediaticidade e de ritmo. O ritmo é uma forma ou padrão básico de movimento, que é seguido pelas transformações ocorridas nas experiências. Na experiência estética, o ritmo refere-se a integrar partes de outras experiências de modo a produzir a fusão dessas partes em um significado inteiro e ainda não visto, estreitamente relacionado com fazer a situação progredir de um modo específico na direção do cumprimento de propósitos de uma prática. É o ritmo de sintetizar relações que fazem seguir para diante, um ritmo de expectativa e fechamento. As relações construídas como parte de um empreendimento, quando sintetizadas na experiência estética geram expectativas que fazem avançar em um trajeto singular, até o encontro de algo que então será reconhecido como um propósito, uma realização de expectativas. No desenrolar e na consumação desse processo, experimenta-se - tomando emprestada uma expressão de Drummond para o amor - o sabor de "um ganho não previsto"; a propósito, se este é um ganho não previsto, por outro lado ele é esperado e acalentado.

Ainda em relação ao ritmo, tem interesse observar que, não sendo exclusivo de um contexto peculiar - por exemplo, uma atividade na aula de ciências - mas tratando de uma característica que afeta a experiência estética em toda sua riqueza e diversidade de modos e contextos, vem a ser uma ponte através da qual cada experiência estética singular liga-se a outras antes e depois dela. Assim, o ritmo dá lugar à continuidade da experiência estética com a vida em geral: uma experiência estética de expectativa ou consumação informa outras expectativas e consumações relacionadas em um momento 
posterior. Afirmar isto, no entanto, não equivale a concluir que se deve buscar puramente na forma assumida pela experiência - descrita pelo ritmo de totalizar e impelir para diante - a razão substancial pela qual ela assume seu caráter estético. Devese evitar encarar o ritmo estético como uma forma ou processo abstrato que exista independentemente e que preceda a todo e qualquer conteúdo. Forma e conteúdo modificam-se reciprocamente (Wickman, pp. 68-72). Para uma apreensão estética ser possível, é fundamental notar a particularidade dos ingredientes que fazem de cada experiência uma totalidade singular: eventos, objetos, ações, agentes e seus modos de execução, e o que mais houver. Tudo aquilo que produz as circunstâncias da elaboração que está em curso, combinado ao uso de um jogo de peças de outras experiências, agora retomadas, irá afetar os aspectos que são discernidos, as expectativas que são geradas e o modo ou processo pelo qual essas expectativas se encaminham para uma realização. Em síntese, um conteúdo específico acaba conferindo uma identidade ímpar à forma do ritmo. As relações relevantes deixam de ser visíveis quando são menosprezados os processos contextualizados em que elas foram construídas, pois em parte são estes que dão substância àquelas. $\mathrm{O}$ modo como se aprende afeta aquilo que se aprende.

Ademais, entender a estética como experiência junto com Dewey implica em tomá-la, em sua plenitude, como algo partilhado e comunicável. A experiência estética, enquanto experiência, compreende a construção de um vínculo pessoal com um conjunto de significados coletivos. Um relacionamento de intimidade se estabelece na participação ativa da pessoa em esforços compartilhados, como parte de um processo que envolve coletar materiais tirados de situações variadas e, pela superação de certos desafios, conseguir reordená-los de modo a realizar um grau de equilíbrio mais elevado do que o que existia entre eles até então. Neste percurso, o indivíduo passa a fazer parte de uma rede de relações, e sua condição mental não pode ser apreendida de maneira isolada dos encontros e significados realizados no meio:

Experiência é o resultado, o sinal e a recompensa daquela interação entre organismo e ambiente que, quando é conduzida à plenitude, é uma transformação de interação em participação e comunicação. (Dewey, citado por Wickman, p. 20)

As idéias de Wittgenstein sobre a produção de significado complementam o entendimento da experiência estética desenvolvido até este ponto. Inspirado nelas, 
Wickman (p. 65) aponta que "Aprender a usar uma palavra de estética não se identifica com aprender uma definição" em termos de uma qualidade essencial e universal a que essa palavra faz justiça. Em atividades inseridas em modalidades de ação humana conjunta, termos com implicações ligadas a beleza e feiúra são colocados para assumir papéis funcionais. A estética está relacionada a como uma tarefa é colocada em movimento em circunstâncias específicas e a como o curso desse movimento é dirigido, ou seja, está relacionada à dinâmica de uma atividade situada. Sendo assim, a aquisição dos significados de um termo estético é realizada - seja por uma pessoa na vida em geral, por estudante em uma disciplina, ou ainda por um pesquisador em uma investigação - pela observação. Em um número grande de ocasiões reunidas sob uma mesma classe, a atenção deverá assim se dirigir: primeiramente, a padrões existentes nos modos como tipicamente o termo se integra às ações desencadeadas no palco de uma atividade; em segundo lugar, às conseqüências sobre o movimento da atividade que se seguem ao uso desse termo; e finalmente, às variações, ligeiras ou profundas, no significado do termo, ocorridas em virtude de sua participação nos resultados alcançados na atividade e na transformação da experiência que ela acarreta. Entender o significado estético produzido na participação em uma prática compartilhada pela perspectiva de Wittgenstein e Dewey implica, assim, em ter atenção a aspectos situacionais como: 1) quais eram as circunstâncias em que a experiência se sucedeu, ou ainda, que assunto, que conteúdo ela possuía; 2) como as relações construídas no uso de palavras e expressões fizeram a atividade avançar; 3) a que os participantes se referiam habitualmente em aprovação ou desaprovação, sobre o que eles manifestavam concordância ou discordância, negando de imediato que fosse quanto a suas representações mentais internas ou a propriedades factuais do objeto ou evento.

Observa-se qualidade estética em uma experiência quando se a vê unir elementos que antes se achavam esparsos em outras experiências, partilhando a percepção das relações que eles estabelecem entre si a partir de um olhar situado no contexto de uma prática em curso, e testemunhando o modo único como aquelas relações transformam a experiência, fazendo-a progredir através de uma trajetória não idêntica a nenhuma outra. Em uma experiência estética, ocorre de seres humanos serem transformados ao mesmo tempo em que transformam os sentidos pré-estabelecidos de coisas, eventos e ações. Essa descrição encontra ecos na visão da estética de Goodman, que também fala da formação de hábitos e aprendizagem de regras de uso de 
predicados, e retrata a qualidade estética de uma experiência como dizendo respeito à percepção de similaridades e distinções inusitadas que têm por conseqüência a transformação no conhecimento do mundo pela revelação de aspectos novos dele.

\section{$4 \quad$ A imediaticidade das experiências estéticas}

Tipicamente, o uso de termos estéticos é dotado de imediaticidade, seja no cotidiano como também em situações de aprendizagem científica. Conforme salienta Wickman (p. 129), “dúvidas com respeito a se uma experiência inédita realmente deveria ser referida pelo uso de um termo estético específico jamais redundavam em uma discussão sobre o significado dos termos estéticos enquanto tais". Quando uma linguagem é imediata, as consequiências do seu uso em uma situação particular são prontamente compreendidas, sem nem mesmo alguma hesitação: o que pode ser questionado é unicamente se o uso feito da palavra constrói ou efetiva relações apropriadas aos propósitos da atividade, i.e., se são relações que dão seqüência à atividade em uma direção que promove propósitos próprios a ela. Conforme explica Kant, é em virtude de a experiência estética ser imediata que o juízo estético parece como se fosse, ao mesmo tempo, uma descrição de uma qualidade inerente ao objeto, e a expressão da experiência interna de um sujeito. Neste sentido, a imediaticidade da linguagem estética significa que os participantes de uma situação específica - incluindo professores e estudantes em uma aula de ciências não interrompem sua atividade para questionar o que qualquer um deles pretendeu dizer ao enunciar uma expressão estética. Eis, para a concepção pragmatista, o que está em jogo quando o discurso e a ação fazem sentido: o reconhecimento pronto de que existe correspondência entre os pontos de chegada de uma atividade em que se é participante e as conseqüências das relações que são tecidas mediante a seleção e o ordenamento de determinado conjunto de palavras e ações.

Wittgenstein chama atenção para o fato de que, devido ao peso que tais relações - construídas para se ajustar às exigências de situações específicas - têm na produção dos significados das palavras, não há como capturar esses significados em definições ou regras explícitas, conforme explica Wickman no trecho a seguir: 
"Saber o que uma palavra significa não implica conhecer de antemão uma definição dela que possamos aplicar em cada situação nova em que a palavra é usada. Apenas pelas conseqüências que se seguem do uso em toda e cada nova situação é que podemos novamente saber se de verdade conhecíamos o seu significado" (Wickman, p. 124).

A inteligibilidade de uma palavra é dependente da participação das pessoas em práticas nas quais vão sendo tecidas relações de palavras, coisas e ações na comunicação. "Wittgenstein mostrou que uma descrição exaustiva de todas essas relações para todos os contextos possíveis não é factível" (Wickman, p. 131). Mesmo assim, qualquer pessoa familiarizada com uma prática determinada saberá apontar ocasiões em que há uma violação nas regras de uso de um termo, pois esta pessoa realizou a aprendizagem de normas implícitas sobre como se deve ou não aplicar palavras dentro do contexto daquela prática em particular. O uso da linguagem e o seu significado são, pois, apreendidos no uso, e não pela leitura de uma gramática: em vez de estarem dadas de antemão e produzirem o fundamento, a razão que origina as ações abrangidas por uma prática, suas regras são, na verdade, resultado da participação na prática em questão. Um corolário disso é que não é possível isentar o significado de um termo do seu envolvimento em um contexto humano. Que o uso de um termo faz sentido dentro de determinada relação é algo que se apreende somente no uso, no encontro com o mundo e com outras pessoas. Compreender um significado não é ter adquirido uma cópia mental exata de uma definição do termo ou expressão, e sim ter adquirido a habilidade de saber como manejar as consequiências em ação do seu uso em uma situação específica. Conclui-se a partir daí que termos e expressões estéticos ganham significado em virtude das relações que foram estabelecidas no interior de uma miríade de situações anteriores em conjunto com ações e palavras de outras classes, e por meio das conseqüências que essas relações tiveram para o prosseguimento dado às respectivas situações. Reciprocamente, a firmeza e o caráter substancial de novos modos de uso do termo ou da expressão estética são consolidados, por um lado, por sua transferência bem sucedida para experiências repetidas e cada vez mais complexas em que, por seu intermédio, são efetivadas antecipações ou realizações dos propósitos correspondentes a uma atividade; ao lado disso, o modo eficaz com que sua estreita conexão em relação a tais propósitos passa a ser compreendida, comunicada e compartilhada também é um fator de entrincheiramento dos significados novos que tais 
palavras adquirem ao adentrar o novo contexto. É possível imaginar o quão complexos vão se tornando os modos de uso de uma palavra depois de ela ter percorrido trajetos tão longos e tortuosos, em intermináveis ciclos nos quais texturas de significado são urdidas e desmanchadas. A característica de imediaticidade exibida por determinados usos de linguagem e ações em circunstâncias específicas é a base que abre espaço para a efetivação de novas relações entre ingredientes de antigas experiências. Esta é uma maneira possível de caracterizar os processos de aprendizagem e a historicidade de seus conteúdos. Seguindo a metáfora de Wittgenstein, a imediaticidade de atos de fala e de outras ações é para a transformação de experiências o que a fixação das dobradiças é para a possibilidade de abrir uma porta. Para tomar impulso em direção ao novo, é necessário ter os pés plantados sobre o velho. É necessário explorar com mais minúcia em que consistem esses jogos recíprocos em que a imediaticidade se acha envolvida.

Tanto na preparação como na efetivação de um fechamento consumatório para uma atividade, ocorre de um grande número de relações relevantes ser sumarizado em uma experiência unitária mediante a aplicação de linguagem estética imediata. É exatamente no momento dessa aplicação, e por meio dela, que se transmite a notícia de que algo que é correto ou verdadeiro no contexto de uma prática foi visto ou alcançado. A imediaticidade inicial de um termo estético, decorrente da continuidade que seus usos têm com a vida em geral, agora se expande e passa a contagiar o complexo formado a partir das relações estabelecidas em uma ocasião singular. A conjunção de experiências parciais que ali acontece passa a ser percebida como imediata. Termos e expressões estéticos transportam e transmitem essa carga perceptual consumatória como razão: eles sintetizam uma justificativa final para decisões relativas a como se deve proceder e a que objetos e eventos se deve selecionar a fim de levar uma atividade a cumprir expectativas da prática em que se acha inscrita. Uma percepção imediata é, portanto, a experiência de algo que antecipa ou realiza uma consumação. Wickman analisa um diálogo retirado dos registros feitos por ele de aulas de laboratório de química na universidade, no qual o professor faz uso de um termo estético para o efeito de oferecer fundamentação para o modo como os estudantes deveriam proceder nas determinações de suas amostras desconhecidas:

"A referência do professor de química ao termo "elegante" deu a palavra final a respeito da razão pela qual os estudantes deveriam usar o menor número 
possível de testes para descobrir quais substâncias seus tubos de ensaio continham" (Wickman, p. 130).

O exemplo trata de uma particular situação de aula de laboratório em que o termo estético exerceu a função de dirigir a atenção dos estudantes para discernir um preceito que opera no interior das práticas da ciência da química. Esse preceito estabelece o valor comparativo, do ponto de vista do modo como promovem propósitos caros à química, de procedimentos analíticos que lançam mão de maior ou menor número de testes para definir os componentes presentes em uma solução. É importante que se note com respeito a esse exemplo que, apesar da relação com a propriedade de uma caracterização de ser obtida com o menor número possível de testes, o termo "elegante" não pode ser simplesmente tomado como sinônimo desse atributo. Se assim fosse, a justificativa apresentada pelo professor na aula de laboratório não passaria de uma tautologia, e não introduziria nada de novo. O significado da palavra guarda reminiscências de seus usos relacionados a outros contextos, a partir e em virtude dos quais ela foi transferida com significado modificado para o domínio da análise química de amostras. Seu uso traz para as condutas de laboratório da química implicações de fineza e requinte, de sagacidade e estilo relativos a um modo de agir. Vê-se, desse modo, que a transformação no significado de uma palavra caminha pari passu com sua continuidade. Em resumo, a emissão de um juízo estético carrega em si uma conjunção sintética de significados mais elementares, conjunção esta à qual passa a corresponder um significado sintético único, singular e próprio. A imediaticidade de termos e expressões estéticos alicerça o desenvolvimento de uma experiência estética imediata. Nesta, os elementos deixam de ser percebidos de maneira individual, e tornam-se visíveis nas relações que estabelecem dentro do todo. Os elementos são percebidos não mais dentro da ordem cronológica em que foram introduzidos, tampouco na ordem linear dos argumentos de um raciocínio lógico, mas ressurgem com novos significados dentro de uma configuração inédita. A consciência os apreende de modo simultâneo, de uma só vez.

A imediaticidade da experiência estética se intensifica como fruto de um processo ao longo do qual juízos estéticos que costumavam ser feitos em relação a qualidades fatuais de objetos, eventos e ações passam a ser considerados juízos sobre o objeto em si: o juízo estético ganha direito a ser encarado como uma descrição factual do objeto. Ocorre neste caso algo como uma aderência do predicado estético ao objeto 
que ele denota. Alcançar a imediaticidade em percepções de objetos, fatos, conceitos, razões e procedimentos pertencentes a um domínio da ciência é um alvo que se coloca para a educação científica.

\section{$5 \quad$ O encaixe entre o conhecimento científico e os significados de experiências estéticas}

De tudo o que emerge das considerações epistemológicas tecidas no princípio do capítulo, interessa, neste momento, dar atenção particular à questão da compatibilidade entre saberes da experiência e conhecimento científico, e da fecundidade de uma eventual interação entre eles. Partindo da constatação inicial de uma divergência tão pronunciada entre o propósito de generalidade que está posto para os produtos da investigação científica e a validade singular dos significados formados na experiência estética, é lícito perguntar que impulsos estes teriam a dar em direção à consumação dos objetivos das ciências e da educação em ciências. Para começar a seguir a trilha correta, é de grande auxílio recolher as pistas deixadas por Feynman neste excerto de sua autobiografia intitulada "Surely You're Joking, Mr. Feynman!":

Se você está dando aulas, você pode pensar nas coisas elementares que você conhece muito bem. Essas coisas têm algo de divertido e prazeroso. Não faz mal algum pensar nelas uma vez mais. Existe um jeito melhor de apresentá-las? Existem problemas novos de algum tipo associados com elas? Haverá novas maneiras de concebê-las? As coisas elementares são fáceis de pensar; se você não consegue pensar em algo novo, não tem problema; aquilo que você pensou antes é bom o bastante para a aula. Mas se você consegue apreender alguma coisa nova, você fica um bocado satisfeito de ter um novo modo de olhar para aquilo. (Feynman, citado por Wickman, p. 12)

Em seu estilo bem peculiar, Feynman põe em evidência nesta passagem o entendimento de que, no interior de uma única peça de conhecimento da física - e por que não da química, da geologia, ou de qualquer outra disciplina científica? comumente se abrigam múltiplas unidades daquilo que ele chama de "novos modos de olhar". Seguramente, a multiplicação de maneiras diferentes de compreender um mesmo 
capítulo da ciência deve ser rejeitada caso se aceite que o núcleo daquilo que o conhecimento científico tem a oferecer de valor são leis naturais com significados determinados de maneira unívoca e absoluta. Porém, ao contrário disso, Feynman testemunha que, a depender da rota efetivamente escolhida para realizar a aproximação do tema visado, um sentido distinto deste mesmo tema é descortinado. Os materiais de experiência encontrados ao longo desta rota e outros que para ela são transferidos somam-se para construir um inteiro conexo de significado singular. Para lançar mão de uma metáfora matemática, poder-se-ia dizer que este é um caso em que o valor da integral depende da trajetória. Sobretudo, Feynman afirma que a transformação na percepção é um valor da ciência. E ainda há mais: um importante sintoma se manifesta quando Feynman se utiliza de termos como "divertido", "prazeroso" e "satisfeito" para se referir ao valor das percepções singulares na ciência. Está bem claro que todos esses termos possuem conotações estéticas na fala de Feynman. Em suma, o trecho anterior nada mais é do que uma descrição do papel que as experiências estéticas exercem na ciência. A solidez deste papel se sustenta na observação de que existem surpresas guardadas naquelas "coisas que conhecemos muito bem”. A experiência estética é a experiência de ocasiões em que se consegue romper a couraça das visões comezinhas para olhar para o "mundo real" de todos os dias e enxergá-lo como se fosse pela primeira vez. Conforme atesta o depoimento de Feynman, não há dúvidas de que a ciência seja um território altamente adequado para ensejar este tipo de percepção.

Nesta cascata de trajetórias que finamente se bifurcam ao considerar um velho tópico uma vez mais, no momento em que algumas delas são percorridas os significados que reluzem demandam ser assinalados. Em meio aos materiais que são encontrados no roteiro singular efetivamente seguido pela atividade de exploração de novos sentidos, incluem-se objetos, eventos, condutas, experiências anteriores, propósitos cognitivos e exploratórios. Entre estes elementos de experiência, de um lado, e certos termos da linguagem estética, de outro, relações poderão ser firmadas tecendo uma rede de significados, caso a exploração seja bem sucedida. O uso de juízos estéticos positivos nestas situações se ajusta para produzir uma síntese a partir das relações que vão sendo construídas entre as peças da experiência em curso e de outras antecedentes: ela funciona como cimento para ladrilhos de experiências anteriormente desconexas. A totalidade de experiência assim produzida ganha uma carga de expectativa, de tendência clara para uma finalização e, por essa mesma razão, ela imediatamente adquire, para 
todos os que se engajam na exploração, papel análogo ao de um mapa. Desse modo, juízos estéticos assumem a função de sinalização e orientação da navegação nos roteiros de produção de significado que são abertos, atuando na distinção de rotas que acenam com a promessa de uma realização de propósitos ao mesmo tempo estéticos, normativos e cognitivos. A estética entra, portanto, como elemento desencadeante da diferenciação de um significado geral em múltiplos significados distintos com ele compatíveis. Provocar e dirigir um movimento de busca é o seu papel. Em outros termos, ela está atrelada não a uma mera sucessão, mas à transformação de experiências, tal como diria John Dewey, ou, ainda, à aprendizagem, conforme afirmaria Ludwig Wittgenstein. Em antecipação a pontos que serão explicitados mais adiante, as generalizações da ciência se encaixam com os sentidos singulares da experiência estética assim como uma mesma peça de música se ajusta às transformações de significado que ocorrem na transição de uma performance para outra. Desse movimento, pode até acontecer de surgirem novas peças, i.é, novas reivindicações de conhecimento generalizado. A partir da continuidade pode ser produzida a variação.

Retomando a discussão epistemológica iniciada anteriormente, é necessário entender, neste ponto, que a função de um mapa não é a de justificar a validade daquilo que está no território, e sim de negociar com ele de maneira a propor e promover formas novas e relevantes de orientação. Todo mapa implica em uma redução do real, e toda redução é sempre objeto de um procedimento de seleção. O ponto é que, em geral, esta seleção não é única, mas se apresenta em um terreno aberto, autônomo em relação a decisões tomadas em bases objetivas. A escolha de um mapa deve privilegiar certos aspectos do território a ser incluídos e deixar outros de fora. Não existe o mapa verdadeiro: existem mapas adequados a propósitos diversos. As informações provenientes do assim chamado mundo exterior não têm o poder de ditar escolhas por antecipação, tampouco têm precisão suficiente para poder excluí-las em definitivo. A ciência não é guiada por estados predeterminados do mundo totalmente independentes de procedimentos humanos de escolha. Não se dá de existir uma rota predefinida que conduza para a única solução, a não ser para os casos mais triviais e sem interesse. Assim, o uso da linguagem estética não tem por objetivo denotar com exatidão e completeza certas regras gerais em vigor para os objetos do mundo exterior ou para os estados mentais internos das pessoas que tomam parte na experiência estética. Sua função é proporcionar veículos nos quais pessoas envolvidas em um empreendimento 
de significação possam embarcar e ser conduzidas por uma jornada partilhada. Isso equivale a criar participação, a tornar comum o que antes era isolado e singular. Tomar parte em uma experiência estética é envolver-se em uma integração e partilhar modos de discernir. Acha-se aí uma das principais tarefas da educação em geral, e da educação científica em particular.

O fato aludido há pouco - de que, de uma mesma unidade bem delimitada e bem compreendida de saber científico, podem vir a brotar muitas ramificações resultantes de processos de experiência singulares - sugere a possibilidade de que ocorra também o movimento inverso: que as soluções construídas para um problema em aberto partindo de decisões, perspectivas e modos de discernir estéticos diversos tenham no final demonstrada, mais que a sua compatibilidade, a sua complementaridade. Também neste outro sentido, a estética é posta em ação para provocar e guiar um processo de busca. $\mathrm{O}$ mecanismo é idêntico: no esforço realizado para fazer uma busca avançar, relações entre elementos de experiência são construídas; a partir de uma eventual fusão destas relações que tenha sido alcançada, o processo é revestido de expectativas de realização que servem de referência para direcionar a busca para um fechamento consumatório. Situações deste tipo estão presentes na história da ciência. Por exemplo, a controvérsia nas origens da mecânica quântica causada pelas perspectivas nitidamente discrepantes que alicerçavam a versão de Schrödinger e a de Heisenberg, respectivamente (Miller, pp. 56-63). Para solucionar o problema da medição de observáveis e da evolução temporal das entidades do domínio atômico, Schrödinger desenvolveu sua mecânica ondulatória guiado por um compromisso de continuidade com as visualizações da física clássica. Por outro lado, em sua exploração do mesmo problema, as expectativas que impeliam Heisenberg firmavam relação com a ruptura entre o mundo atômico e a intuição que é gestada na imersão da experiência humana no mundo das percepções sensoriais; Heisenberg desde o princípio decide abolir a visualização de sua mecânica matricial, dando preferência a uma visualizabilidade que deverá ser fornecida pelo arcabouço matemático da teoria. As assim chamadas representações de Heisenberg e de Schrödinger da mecânica quântica fornecem, desse modo, duas versões de um problema físico único, fundadas em experiências de conteúdos normativos e estéticos distintos: uma delas consolidada com materiais abstraídos do comportamento familiar de ondas; a outra inteiramente construída de elementos sem qualquer correlação com aquilo que se pode abstrair das percepções, elementos de uma experiência de natureza radicalmente 
matemática. Apesar de tamanha disparidade, trata-se de versões igualmente verdadeiras. Caso seja tomada a decisão de equiparar o significado de verdade à coerência lógica e ao grau de acordo empírico alcançado por essas versões, dever-se-ia considerá-las idêntica uma à outra. No entanto, importa observar aqui a necessidade de um sentido mais abrangente de verdade, que não diga respeito exclusivamente aos critérios lógicoempíricos unívocos, mas que dê conta de capturar adequações na pluralidade de escolhas e modos de proceder estéticos utilizados, e ateste a correção das visões distintas dos fenômenos que são produzidas em consequiência. Os produtos finais generalizados que os formalismos de Schrödinger e Heisenberg corporificam não exaurem, por si sós, os significados dos tipos diferenciados de experiências singulares dentro das quais estão absorvidos. Por isso, em vez de dizer que as versões são verdadeiras, dar-se-á preferência a dizer - nos termos visitados anteriormente - que são versões adequadas ou corretas. Traduzido para a teoria de símbolos de Nelson Goodman, isto equivale a dizer que o mundo da versão de Schrödinger da mecânica quântica não é o mesmo da versão de Heisenberg. Cada um destes mundos resulta de procedimentos de construção bastante diferentes. Expor cuidadosamente que mundos são estes - e não apenas ter preocupação com o desenvolvimento de uma perícia em manipular o formalismo matemático para resolver problemas numéricos - acarretaria um inestimável enriquecimento da educação em ciências.

Paralelamente, no seio desta discussão da compatibilidade entre ciência e experiência estética se insinua uma possível solução para a questão das discrepâncias nos juízos estéticos enunciados em relação ao mesmo objeto ou evento. A situação poderia ser delimitada nos seguintes termos: até o momento pôde-se perceber que a aplicação de um predicado estético positivo tem por conseqüência que o item por ele referido é algo a ser guardado, conservado, em razão de mostrar ou antecipar credenciais para fazer a atividade em que ele comparece prosseguir na direção de uma consumação. Por outro lado, em juízos estéticos negativos os predicados são atribuídos para o efeito de dar destaque a algo que deve ser excluído ou evitado por levar a atividade à paralisação. Não raro, depara-se com episódios de conflito entre julgamentos estéticos emitidos a propósito de um mesmo objeto por indivíduos igualmente bem qualificados para ajuizar a questão. A controvérsia entre Heisenberg e Schrödinger referida pouco atrás é um caso paradigmático. A escolha que um deles afirma merecer que seja incluída na prática da física é rejeitada com razões igualmente fortes pelo 
outro, e vice-versa. Em vista das características da experiência estética delineadas até este ponto, é lícito conjecturar que, na maioria destes casos, haveria como discernir que o alvo dos julgamentos não constituiria um único objeto abstrato geral, senão muitas totalidades concretas e singulares abrigadas como exemplos da mesma abstração. Daí a conclusão de que tais concreções poderiam ser - embora não obrigatoriamente cheguem a sê-lo de fato - todas simultaneamente verdadeiras ou, melhor dito, corretas. Em se configurando este estado de coisas, as suspeitas que costumam pairar sobre a experiência estética de irracionalidade, de carência de significado e de serem meras projeções de preferências pessoais devem ser reavaliadas.

\section{Limitações da concepção cognitivista de aprendizagem}

A fim de ir ao encontro de razões que nos levem a acreditar na viabilidade de acomodar as experiências estéticas dentro da educação nas ciências físicas é necessário problematizar duas noções e a relação que elas mantém entre si. São elas: a noção de significado e a de aprendizagem.

Influenciadas por uma moldura cognitivista hegemônica, a maioria das pessoas tem a tendência a pensar que o significado do conhecimento produzido pela física esteja confinado em unidades abstratas fechadas, formadas por regras e definições. Disso decorre diretamente o entendimento de que aprender seria o mesmo que adquirir cópias mentais dessas unidades abstratas — os assim chamados modelos mentais. Partindo dessa perspectiva, o conteúdo de juízos estéticos não pertenceria à classe de evidências que teriam função na apreciação racional, visto que uma coisa variável e particular deve ser excluída do diálogo com outra imutável e geral. Por conta disso, sua relevância para a aprendizagem estaria automaticamente descartada:

Para a corrente principal da ciência cognitiva, aprendizagem nada mais é do que um processo cognitivo e, por essa razão, racional que se relaciona com a construção e reconstrução de representações mentais do mundo externo em termos de processamento de informação. Por isso, ela não encerra emoções e experiências estéticas, porque experiências de alegria ou mistério, ou de beleza 
ou feiúra por dizer nisso, não são representações do mundo que como tais possam ser avaliadas como verdadeiras ou falsas (Wickman, p. 40).

Há, no entanto, razões suficientes para discordar dessa visão de inspiração popperiana - segundo a qual aprender requer a transformação completa de estruturas de conhecimento e se processa essencialmente como teste de hipóteses. Primeiramente, a legitimidade do uso da linguagem não se restringe à demonstração da existência no mundo de entidades que correspondem ao que é dito, independentemente da possibilidade humana de dizê-lo ou simbolizá-lo de alguma outra maneira. Em segundo lugar, essa visão não abrange toda a variedade de modos em que a aprendizagem pode ser observada e que são profícuos a ela. Wickman apresenta elementos demonstrativos de que

“essa exclusão [da estética] é feita em fundamentos puramente a priori, sem qualquer base em estudos empíricos de processos de aprendizagem em práticas humanas ou cenários educacionais reais" e que "a aprendizagem envolve mais do que testar a coerência lógica de idéias ou compará-la com a evidência empírica. (...) [este] é somente um dos modos de aprender sobre o mundo, mesmo na ciência". (p. 41)

A titulo de exemplo, considere-se a situação particular de determinada atividade educativa em curso, inserida como parte de uma disciplina científica. Nesta situação, o singular representado por acontecimentos, objetos, ações e falas ali encontrados exerce influência sobre os significados que serão produzidos pelas pessoas que participam da atividade. Em operação aqui, encontra-se o princípio de que as diferenças em "como" se aprende acarretam diferenças em "o que" se aprende. O que se pretende com esta afirmação é salientar a influência que os componentes contextuais de significado, somente encontrados na experiência de situações particulares, exercem sobre a compreensão científica que será efetivada. O modo como tais elementos circunstanciais modelam a compreensão diz respeito não somente à atenção que se pode dar a cada um deles de maneira isolada, mas, sobretudo, ao modo singular como esses componentes são tramados no decorrer da atividade compartilhada, e as consequiências dessa trama sobre o roteiro efetivamente seguido pela experiência educativa.

Uma nítida observação de como a aprendizagem se estende para além da preocupação com testar a verdade de proposições universais foi realizada por Wickman 
(pp. 42-43) em aulas de laboratório de zoologia. Ela focaliza um momento de estudo da estrutura morfológica e da identificação de partes do corpo de insetos. Em alguns dos espécimes disponíveis no acervo didático do laboratório, certas estruturas corporais não estavam totalmente preservadas: poderiam faltar, por exemplo, as antenas. Ao lado disso, a mesma estrutura nas múltiplas espécies distintas que ali estavam representadas exibia uma variação anatômica muito ampla. Considerando que se tratava de um grupo de estudantes com pouca experiência nas distinções praticadas na zoologia, a situação fazia recair uma enorme incerteza sobre decisões procedimentais que deveriam tomar para a correta identificação das partes dos insetos. Mesmo assim, percebe-se claramente que, da regra de que todos os insetos têm um par de antenas, o que os estudantes faziam não era confrontá-la com as amostras de que dispunham para ver se era verdadeira ou falsa, senão tomá-la como uma experiência consolidada no passado e usá-la como apoio para aprender o significado da diferença de formato das antenas entre diferentes insetos, incluindo aqueles com danos. Conforme observa Wickman, aqueles estudantes buscavam

(...) ver o que essas generalizações já prontas significavam em termos do inseto único que tinham à mão no momento. (...) Em acordo com sua necessidade de aprender sobre as idiossincrasias de insetos reais, os estudantes não proferiam uma sentença final - depois de investigar um inseto - em termos universais, dizendo, por exemplo, "sim, insetos parecem ter antenas", mas, de costume, faziam apenas uma afirmação singular como "este tem antenas". No entanto, é certo que eles, não obstante, aprendiam algo de novo a respeito da aparência que antenas podem apresentar, transformando sua experiência prévia em antenas de modo a ajustá-la a esse novo encontro com o inseto particular. (Wickman, p. 42-

Também os significados do conhecimento da física se desdobram entre o formal e o contextual. O significado que se produz para a relação ôhmica entre ddp e corrente elétrica, por exemplo, é diferente dependendo de se a pessoa teve ou não a chance de associá-la a ocorrências particulares de um choque, de uma centelha elétrica, etc.; e seguramente se estabelece uma diferença pronunciada no significado do conceito abstrato de campo magnético quando ele se conecta a experiências de confecção e uso de uma bússola simples. 
Sendo assim, um sentido mais proporcionado para o conceito de aprender é obtido equacionando-o à idéia de processo voltado para adquirir compreensão. Isso passa por aprender a utilizar símbolos de diferentes tipos, observando a maneira como seus modos específicos de funcionamento contribuem para a focalização da atenção em aspectos do mundo até ali não notados e induzem a

uma reorganização de nosso mundo familiar (...) dividindo e combinando categorias dadas, acrescentando e subtraindo, efetivando novas discriminações e integrações, reordenando prioridades (Goodman, 1978, p. 105).

Capturar uma idéia em compreensão diz respeito a conhecê-la para saber como discernir, como sintonizar semelhanças, diferenças, relações, propósitos e exigências que essa idéia implica, e como segregá-la de outros aspectos que não têm relevância para ela. Falar em compreensão significa fazer referência a significados que não são fixados para todo o sempre, mas que vão se transformando ao longo de sucessivos encontros particulares. No curso desses encontros, uma pessoa pode muitas vezes vir a notar objetos e acontecimentos com características que entram em conflito com uma afirmativa geral. A considerar as experiências diárias dos indivíduos, todas as observações mostram, por exemplo, que o que está em movimento tenderá inevitavelmente para o repouso. São observações, portanto, que entram em confronto direto com o enunciado universal da lei da inércia. Em face dessa constatação, a estratégia de aprendizagem não deve ser a de refutar a lei da inércia com base nas observações cotidianas; pelo contrário, o modo correto de proceder é reinterpretar cada uma daquelas observações tomando a lei universal como referência. Ao longo dessa releitura, o indivíduo responsável por realizá-la passa a ver as situações de coisas em movimento por um novo ângulo: ele assim refina, estende e aprofunda sua compreensão. Ao final, se estabelece para ele uma diferença colossal entre o significado da lei da inércia no abstrato, até onde esta lei permanece desligada de observações concretas, e o significado que ela adquire somente ao ser usada pelo indivíduo para reinterpretar os exemplos particulares encontrados no seu dia-a-dia.

Nestes exemplos, está patente a diferença em conseqüência prática entre uma regra universal abstrata e o conteúdo de uma experiência singular relacionada com essa mesma regra: a primeira requer seja submetida permanentemente a testes, ao passo que o segundo é para ser estendido e gradualmente reajustado em situações novas nas quais 
seu uso tem proveito. Aprender tem a ver não só com testes de hipóteses, mas também com ir aos poucos começando a partilhar dos modos como regras são usadas no âmbito de uma prática em particular, a fim de fazer distinções de aspectos relevantes àquela prática. No exemplo mencionado anteriormente do estudo da morfologia de insetos, era importante que os estudantes aprendessem a decidir se o que viam era uma parte do inseto, ou um grão de pólen colado a ele, ou um dano em sua estrutura, ou ainda se aquilo que viam era mesmo aquele órgão que procuravam ver (Wickman, p. 43). Somente no encontro com exemplares singulares um estudante pode aprender essas distinções, e somente se vier a dominá-las ele poderá vir a fazer parte da prática da ciência zoológica.

Em suma, extraem-se das discussões realizadas até aqui algumas características fundamentais do significado de estética que serão levadas adiante nesse estudo. Situando no centro da estética das criações intelectuais humanas a idéia de compreensão, três implicações são acentuadas:

1) A alternatividade de experiências de uma mesma unidade abstrata: o significado de uma unidade abstrata de regras e definições vai sofrendo reajustes à medida que ela é aplicada a uma série de situações particulares; esses reajustes vão gerando um espectro de diferentes experiências da mesma unidade abstrata de conhecimento.

2) A transformação da experiência pela aprendizagem de novos modos de ver originados na produção de totalidades de significado. Essas totalidades se baseiam na interconectividade entre dois lados: fatos e normas da física e o sentimento de concordância/discordância com esses fatos e normas. Em outras palavras, que não apenas o estudante seja exposto aos fatos, mas que lhe sejam dadas condições para desenvolver uma capacidade de sentir e de imaginar aqueles fatos como corretos.

3) A comunicabilidade do significado da experiência estética, em razão de que o uso de termos estéticos em situações compartilhadas pode produzir sobre estas resultados que são observáveis. Pessoas que estão conjuntamente engajadas em uma atividade com propósitos podem assim formar um cabedal de experiências compartilhadas. 


\title{
A apreciação estética de peças de conhecimento científico ou, por que o conhecimento científico pode ser belo
}

\author{
O pano então cai!
}

Ludwig Boltzmann

\section{Evidências da presença do estético no entendimento dos conceitos científicos}

Por conta do receio de que a consciência da participação de formas de cognição não exclusivamente intelectivas na constituição nos produtos da ciência passe ao terreno da cultura como prova da associação do conhecimento científico com rótulos que ela própria se esforçou para rejeitar como arbitrários e sujeitos à mistificação, e de correr, assim, o risco de ter sua reivindicação ao status de conhecimento objetivo arranhada, boa parte dos cientistas cientes de tais envolvimentos "espúrios" se fiscalizam para manterem a discrição a seu respeito. Contudo, nas experiências que os seres humanos acumulam em interações que estabelecem, seja com os objetos e acontecimentos do mundo das artes, seja com os elementos que originam os diferentes ramos do conhecimento discursivo acerca do mundo humano e natural, ou ainda nas ocorrências da vida comum, aquilo que aí se encontra é marcado por uma enorme complexidade e multidimensionalidade. A fim de dar conta da riqueza imensa dessas experiências humanas e estender a amplitude e profundidade que a exploração do seu conteúdo exige, qualquer pessoa que delas participe é instada a desenvolver a capacidade de se projetar em diferentes perspectivas e a estabelecer um diálogo entre elas, tendo, para isso, de fazer uso integrado de seus poderes intelectuais, emocionais e sensoriais. Sob esse ponto de vista, as características do relacionamento que o homem mantém com suas capacidades mentais nas criações das ciências físicas não diferem daquelas presentes no curso das manifestações de sua criatividade artística, ou mesmo no 
exercício das percepções que povoam o seu dia-a-dia. Em qualquer um desses domínios, sentimentos, pensamento lógico e percepções sensíveis se acham em uma cooperação intensa na qual os limites entre os três tornam-se nebulosos.

Root-Bernstein (2002) é um dos observadores atuais da atividade científica a salientar por meio de suas investigações o funcionamento de operações mentais que guiam o cientista no caminho da solução de problemas científicos em um nível que antecede a sua tradução em uma configuração formalizada, própria a ser avaliada e comunicada nas formas da racionalidade discursiva. Neste nível, os recursos das modalidades variadas de atividade mental se entrelaçam em uma estratégia de operação que Root-Bernstein adequadamente optou por descrever pelo termo sinosia, formado a partir de sinestesia e do radical grego gnosis. O termo lança luz, assim, sobre um modo de cognição resultante da operação complexamente urdida das diferentes formas de percepção sensorial em união com a afetividade e o intelecto (2002, p. 61). Os relatos que alguns cientistas de renome oferecem dos recursos cognitivos que comumente são postos em ação nos lances criativos da sua atividade apresentam um alto grau de concordância ao testemunhar evidências abundantes do uso de um repertório que se afasta tanto da hegemonia exclusiva do intelecto quanto de uma coordenação feita de momentos disjuntos das atividades mentais conhecidas como emoção, intelecto e percepção. Em seu estudo que articula um modelo de mudança científica no qual a interferência de critérios estéticos é conciliada com uma abordagem racionalista da ciência, McAllister (1996) apresenta uma compilação de pronunciamentos públicos de nomes destacados de diferentes campos científicos e, em especial, da física, que assinalam a incidência de fatores estéticos não só no contexto da descoberta, senão também nos momentos de avaliação e justificação das teorias científicas. Uma série de outros trabalhos como esses (Wechsler, 1978; Curtin, 1982; Chandrasekhar, 1987; Jardine, 1991; Tauber, 1996; Miller, 2000) lança bases sólidas para a conclusão de que a apreciação da totalidade dos aspectos relevantes ao conhecimento científico ultrapassa a visão de aquisições realizadas sob a direção de um método rigorosamente obediente aos cânones de um racionalismo cartesiano e justificadas por garantias lógico-empíricas. Esses são os traços com que o saber científico é representado em abordagens que contemplam unicamente a forma final, sistematizada, dos seus produtos, com uma negligência solene em relação aos seus processos de formação. Em resposta a essa lacuna, os trabalhos anteriormente citados dão destaque para a existência de uma 
dimensão estética de extrema relevância para uma compreensão justa e completa do significado das peças de conhecimento científico.

A ligação da estética com a compreensão mediada por conceitos, pela qual a ciência se caracteriza, enfrenta também a resistência de correntes filosóficas influenciadas pelo pensamento dominante da estética moderna. A partir da terceira crítica de Kant, se consolidou a visão de que a experiência estética está vinculada ao domínio estrito de objetos e eventos dos quais o ser humano se dá conta diretamente por meio dos sentidos e de sentimentos, com uma participação apenas periférica da conceitualização. Parece ter sido esquecida uma tradição que remonta aos pitagóricos e que, na filosofia moderna, encontra em Hutcheson o seu expoente máximo. O foco dos pensadores dessa tradição recai sobre a assim chamada beleza intelectual, ou seja, a percepção da beleza que se manifesta na forma e no significado de belas idéias. A situação foi assim resumida por Osborne:

Atualmente, o conceito de beleza intelectual, creio eu, não é tão comumente repudiado quanto é negligenciado; poucas das obras básicas de estética prestam mais que homenagens vazias a ele e não sei de nenhuma que tenha tentado uma análise profunda ou dado a ele o mesmo peso dado às belezas sensoriais na moldagem dos conceitos estéticos gerais. (Osborne, 1964, p. 160; citado por Girod, 2007)

É mais do que evidente, no entanto, que os objetos perceptuais não são os únicos veículos em que a apreensão da beleza se torna possível. Conforme salienta RootBernstein (2002, p. 61), “todas as invenções humanas, incluindo aquelas originárias da ciência, matemática e engenharia, podem evocar a mesma gama e tipos de respostas estéticas que uma bela vista, uma pintura estonteante ou uma sinfonia comovente evocam". Por inspiração dos conceitos de atividade extraídos da psicologia, Osborne (1978) opta por deslocar a noção de percepção de uma associação exclusiva ou principal com a percepção sensorial, preferindo utilizá-la para se referir a todo ato em que um indivíduo se dá conta de algo mediante a focalização voluntária de sua atenção sobre esse algo. Tendo em mente essa compreensão, é possível falar coerentemente "da captação em percepção de características como o enredo ou a caracterização dos personagens de um romance, a adequação à função de uma estrutura arquitetônica ou a elegância econômica de um teorema matemático, em que a percepção sensorial não é 
muito proeminente" (Osborne, 1978, p. 227). Em suma, como objetos estéticos, pode-se ter um objeto ou evento fenomênico, mas também uma entidade abstrata como uma concepção produzida pela ciência, e se optará daqui em diante por chamar qualquer um deles simplesmente de objeto.

Uma vez tendo-se deparado com fortes evidências da existência de um espaço estético imbricado no domínio do conhecimento científico, será construída uma argumentação para tornar essa existência definitivamente plausível e legítima com base nas teorias estéticas de Goodman $(1976 ; 1978)$ e Osborne (1978). Naturalmente ficará claro a partir desses argumentos que, também no tocante ao ensino e aprendizagem da ciência, a experiência do conteúdo das peças de conhecimento científico não precisa ficar limitada apenas àquela parcela que pode ser apreendida desde um ponto de vista analítico, mas deve ser estendida à apreciação do amplo potencial estético que se imbrica nesse conhecimento. Primeiramente, será devotada uma atenção especial aos fatores determinantes de uma atitude favorável ao desenvolvimento de um relacionamento estético com peças de conhecimento físico, levando em conta a natureza dos objetos que são aptos para estabelecer esse modo de relacionamento com um indivíduo.

\section{A apreciação estética como forma de cognição.}

As exigências que se impõem sobre a postura mental que um sujeito deve assumir de maneira a poder estabelecer uma relação de apreciação com um objeto apropriado para isso devem ser coerentes com as características desse tipo de objeto. Em face dessa constatação, levantam-se duas questões: a primeira, relativa aos traços pelos quais se pode identificar a apreciação estética de um objeto ou evento e, em seguida, uma indagação sobre o caráter dos mecanismos e das propriedades por meio dos quais um objeto adquire seu potencial de deflagrar e dar suporte à progressão de tal experiência. Em resumo, atitude estética e objeto estético devem ser definidos a partir de um procedimento autoconsistente, em adição a alguns pressupostos gerais que oferecem uma explicação plausível para a fenomenologia da apreciação. 
Como resposta para a primeira das questões, será adotada a visão da apreciação como aptidão cognitiva. Apesar de conduzirem seu pensamento muitas vezes em direções distintas e de acordo com interesses diferentes, Goodman, Osborne e RootBernstein concordam sobre a interpretação geral de que a motivação da apreciação é o seu valor epistêmico. A atitude apreciativa é movida, não por um desejo de fruir um banho de emoções agradáveis como costumeiramente tende-se a pensar, e sim pela busca de reestruturação, esclarecimento e ampliação do conhecimento do sujeito que assume essa atitude: para os três autores, a percepção estética é uma forma de cognição. Sendo assim, opta-se aqui por seguir a caracterização que Osborne faz da atitude de apreciação estética ao descrevê-la pelo conceito de percipiência. Por percipiência entende-se, basicamente, uma predisposição do sujeito para focalizar sua atenção sobre um objeto, tendo como horizonte o discernimento vivo e uma percepção intensificada das características desse objeto. De um modo mais preciso, trata-se da postura mental básica para a apreciação estética que exige o atendimento de quatro condições:

- primeiramente, a focalização da percepção sobre um objeto de atenção complexo, de que resulta o objeto ser perceptualmente isolado de contextos paralelos que possam desviar a atenção dos propósitos da atividade específica em que a apreciação esteja implicada;

- a capacidade do participante da apreciação de isolar o seu relacionamento com o objeto de toda preocupação com o modo como este poderia promover os fins próprios ao indivíduo e lhe conferir alguma vantagem pessoal. É preciso que se estabeleça o que Edward Bullough caracterizou como uma "distância psíquica" na apreciação estética, a qual se alcança "desengrenando, por assim dizer, o fenômeno com o nosso eu prático e real; deixando que ele fique de fora do contexto das nossas necessidades e fins pessoais, em resumo, olhando-o "objetivamente", como muitas vezes tem sido chamado, permitindo de nossa parte apenas as reações que enfatizam os traços "objetivos" e interpretando até os nossos impulsos ou sentimentos não como modos do nosso ser, mas antes como características do fenômeno". (Bullough, citado por Osborne, 1978, p. 31.)

- em terceiro lugar, portanto, a disposição voluntária para a tarefa de discernir as qualidades estéticas do objeto ou evento e o modo como elas se entrelaçam às características do próprio objeto e às ações e finalidades da atividade em curso; a 
pessoa que se dispõe a apreciar deve se engajar na busca por determinar precisamente quais são os mecanismos responsáveis por conferir ao foco da apreciação uma excelência estética peculiar, esforçando-se por encontrá-los em funcionamento tanto no objeto em si mesmo quanto na prática em que este se acha inserido;

- e, por fim, a possibilidade de que o indivíduo exerça a imaginação, no sentido conferido por Bronowski, operando simbolicamente de maneira a ser projetado para um ponto de vista a partir do qual o objeto da apreciação possa vir a se iluminar e iluminar certos traços ainda inéditos do mundo.

Ao falar da apreciação como cognitiva, e dotá-la das características que se acaba de mencionar, deve-se ter, no entanto, o cuidado de evitar o engano cognitivista: vir a interpretá-la como uma faculdade abstrata e formal, comparável a um programa fechado que a mente processa pondo em ação uma sequiência de procedimentos independentes do contexto específico em que o apreciador esteja inserido. Ao contrário disso, a apreciação é sensível ao contexto e apenas assume uma forma definida ao longo do seu funcionamento no curso de uma situação única, em função dos eventos, objetos e finalidades específicos que esta situação efetivamente esteja comportando. Não é coerente, pois, pensar que o significado produzido na apreciação se esgote em estruturas gerais refletidas em mapeamentos mentais de objetos estéticos; tampouco é possível reduzi-la a eventos neurais que representem emoções deflagradas pela exposição ao objeto.

Ao mesmo tempo, se é certo que o conceito de Osborne de apreciação como percipiência se acomoda no interior da visão de Goodman, por outro lado a interpretação dada por este é mais geral. O ponto do qual Goodman parece partir é o de que, diante da escolha de localizar o valor estético fundamental nas consequiências cognitivas dos objetos estéticos, não faz sentido impor que a apreciação fique restrita à obtenção de conhecimento das propriedades do objeto. De acordo com este autor, seja qual for o tipo do objeto de apreciação - por exemplo, uma música, ou uma escultura ou pintura abstrata, que não possuem função de representação, ou um objeto em que o caráter representacional é proeminente, como na percepção estética de um modelo ou hipótese científica - ele pode possuir um valor estético que vai além da capacidade de elevar a atividade mental do sujeito a um estado cada vez mais dinâmico à medida que 
características do objeto são discernidas e iluminadas na percepção direta. Uma fonte de valor estético que não deve ser minimizada diz respeito à maneira perspicaz com que o funcionamento simbólico do objeto estético pode propiciar a iluminação de aspectos inusitados do mundo. Novamente, este potencial não é prerrogativa apenas de objetos estéticos que possuem função representacional, uma vez que símbolos "opacos" - cuja referência a elementos do mundo é consumada pelo mecanismo da exemplificação também podem lançar a percepção de mundo de uma pessoa para níveis mais profundos e amplos. Em outras palavras, em experiências de aspectos do mundo não diretamente presentificados no objeto estético, mas que só se revelam por meio das reestruturações e descobertas específicas que ele propicia, a qualidade que se encontra nestas últimas integra o valor estético do objeto. Esse ponto é sustentado por Goodman mediante um exemplo típico das artes (Goodman, 1976):

A simbolização, então, deve ser julgada fundamentalmente pelo critério de quão bem ela serve ao propósito cognitivo: pela delicadeza de suas discriminações e pela perspicácia [aptness] de suas alusões; pelo modo como funciona em agarrar, explorar e informar o mundo; pelo modo como analisa, classifica, ordena e organiza; por como participa na formação, manipulação, retenção e transformação do conhecimento (p. 258). (...) O que um Manet ou um Monet ou um Cézanne fazem para a nossa visão subseqüente do mundo é tão pertinente à avaliação deles quanto qualquer confrontação direta. O modo como nossas observações de pinturas e nossas audições de música informam aquilo que encontramos num outro momento e lugar integra esses símbolos enquanto cognitivos. O mito absurdo e desajeitado da insularidade da experiência estética pode ser riscado. (p. 260)

Estes artefatos simbólicos podem ser apreciados quando são deliberadamente colocados em relações com o mundo que se mostram adequadas para sugerir aspectos dele a serem discernidos e novos modos de ver e considerar seus elementos costumeiros. A fruição de um artefato simbólico é completa, portanto, quando se abre a possibilidade de considerá-lo nas relações que firma em muitos contextos distintos e que trazem conseqüências que impelem estes contextos em direção a um telos. Neste caso, ele funciona como instrumento epistêmico que subseqüentemente pode mediar e informar a cognição de outros itens de mundo além de si próprio. Mais adiante, se poderá observar de que maneira as peças de conhecimento científico podem passar a ser 
apreciadas de modo análogo. Antes disso, porém, tem-se aqui nova ocasião para realçar a continuidade da experiência estética. $\mathrm{O}$ modo de entender o cognitivo, o normativo e o estético como categorias separadas e autônomas é relevante e útil para investigações e análises teóricas bem delimitadas que lançam mão de uma divisão como essa para alcançar objetivos específicos. No entanto, nos processos envolvidos na produção de significados e formação da compreensão de um assunto, depara-se com a fusão de aspectos cognitivos, normativos e estéticos, na qual as linhas divisórias entre eles ficam borradas ao serem absorvidos no interior de totalidades de experiência. No curso de um empreendimento, um termo estético pode adquirir valor cognitivo, ou normativo, ou ambos, o análogo ocorrendo com itens que tradicionalmente são designados como normas e fatos. Outra maneira de formular a mesma idéia é dizendo que no engajamento em práticas com propósitos, que incluem atividades comunicativas e têm como fruto a aquisição de saberes e a produção de significados compartilhados, existe continuidade entre fatos, normas e estética. A continuidade cognitiva e normativa da experiência estética sugere, pois, que ela tenha algum papel na aprendizagem de ciências (Wickman, p. 109).

\section{Os sintomas do estético}

Diante do que foi exposto a respeito da atitude de percipiência que está na base da experiência estética, é agora necessário colocar o foco sobre o modo de funcionamento das coisas que servem de objeto para ela. Devem ser identificados os aspectos desse funcionamento em virtude dos quais se justifica a presença das características específicas, já mencionadas, da postura mental que promove uma apreensão eficaz do objeto.

Goodman salienta que a forma de operação de um objeto que confere a ele um potencial estético é flutuante, volátil. De modo muito similar ao que acontece quando uma caixa deixa de exercer a função de receptáculo e passa a funcionar como banco, se alternando entre uma e outra função, também é possível ocorrer ativação e desativação do funcionamento de um objeto como objeto estético. Ele explica que o ir e vir da operação dos fatores que colocam um objeto em condições propícias para a apreciação estética ocorre fundamentalmente em razão de que essa operação é de natureza 
simbólica (1976; 1978). A simbolização, segundo ele, se faz presente até mesmo em obras de arte abstrata, que costumam ser consideradas, sob influência dos manifestos da arte pela arte, livres de qualquer tipo de atuação como símbolos. Todo objeto que é apreciado esteticamente depende, dessa forma, de que o observador detenha o conhecimento - o qual na maioria das vezes se constitui como um conhecimento tácito - de modos específicos de simbolização responsáveis pelo efeito estético, e de que ele seja capaz de sintonizar sua atenção de maneira a apreender a atuação peculiar de alguns deles no objeto. Goodman identifica, dentre as possíveis características dos modos de simbolização que com mais freqüência comparecem no âmbito das artes, um conjunto de cinco delas que correspondem a alguns dos "sintomas do estético" (1976, pp. 252255; 1978, pp. 67-70). Uma nota do significado desses sintomas pode ser apreendida na passagem a seguir, em que eles comparecem despojados das tecnicalidades envolvidas na caracterização rigorosa realizada por Goodman:

Em ocasiões em que nunca podemos determinar exatamente diante de qual símbolo de um sistema nós estamos ou se estamos diante do mesmo símbolo em uma segunda oportunidade, em que o referente é tão fugidio que encaixar adequadamente um símbolo a este referente requer um cuidado sem fim, em que mais e não menos características de um símbolo são relevantes, em que o símbolo é uma instância de uma propriedade que ele simboliza e em que pode realizar muitas funções referenciais simples e complexas inter-relacionadas (...). (Goodman, 1978, p. 69)

Pela ordem de sua aparição na citação acima, tais sintomas são: (1) a densidade sintática, presente quando as mais finas diferenças nas propriedades constitutivas dos símbolos de um sistema são suficientes para produzir símbolos diferentes; (2) a densidade semântica, quando existem símbolos para se referir a casos de uma propriedade que se distinguem pelas mais delicadas diferenças, (3) a saturação, quando os aspectos de um símbolo que são significativos para sua apreciação completa estão em maior número em comparação a símbolos componentes de outro sistema; (4) a função exemplificacional ou exemplificação, quando um símbolo executa uma função referencial por servir como uma amostra de algumas de suas propriedades; e, finalmente, (5) a referência múltipla e complexa, presente "quando um símbolo exerce diversas funções referenciais que se juntam e interagem entre si, algumas delas diretas e outras mediadas por outros símbolos" (Goodman, 1978, pp. 67-68). A presença de uma 
ou várias dessas características de sistemas de símbolos em um determinado objeto aumenta a probabilidade de que esse objeto dê suporte a uma apreciação cada vez mais detida, ampla e aprofundada, e são evidências de que o objeto pode funcionar como símbolo estético. Quando esses sintomas vêm a se substantivar em um objeto efetivamente estético - o que não ocorre necessariamente - esse objeto se abre para uma atitude de busca por discriminações de nuances delicadas no modo de simbolização que ele exerce. A apreensão em percipiência desse modo peculiar de simbolização entra para o repertório de recursos com os quais o apreciador constrói significados e visões de mundo e, na seqüência, permitirá transformar e enriquecer as experiências do apreciador em outros setores.

Tudo o que foi dito até aqui em relação às propriedades de um objeto estético que o credenciam à apreensão em percipiência pode ser sintetizado na conclusão de que, para uma apreciação estética bem-sucedida, é necessário que haja o encontro de dois fatores: um objeto constituído de modo a funcionar como símbolo dotado do potencial de guiar a atenção para um foco determinado, sendo este foco aquilo a que o símbolo se refere se for lido a partir de um sistema adequado e, sobretudo, a partir de como ele repercute sobre os propósitos de uma prática; em segundo lugar, a atenção estética do participante da apreciação precisa estar ativada e voltada para a direção correta. $O$ participante deve, ao mesmo tempo, deter o conhecimento das regras de referência do sistema de símbolos em questão e ter o seu interesse mobilizado de modo a poder sintonizar com o potencial de referência do símbolo estético.

Arte e ciência corporificam dois modos de cognição que devem ser avaliados em termos de como seus produtos se mostram aptos a ampliar e iluminar a percepção do mundo. Exatamente aí se acha a explicação da afinidade entre beleza e verdade: estes dois valores fazem parte de um conjunto de critérios por meio dos quais se avalia a correção de versões diversificadas de que o conhecimento humano se constitui. O valor estético mais básico, do qual todos os demais derivam, está ligado, portanto, com a descoberta do estreito elo entre capacidades sutis de percipiência do mundo e qualidades que são encontradas tanto quanto introduzidas nele em esforços realizados para conhecê-lo - a virtualidade da produção de totalidades de significado, conforme foi destacado no término do capítulo anterior. Dizer que um objeto tem valor estético é uma forma elíptica de dizer que ele tem valor para a apreciação, ou seja, que ele pode funcionar de modo a favorecer a sustentação e progressão da percipiência, a ponto de 
por seu intermédio ser possível seguir discernindo e explorando novas nuances e cursos de um empreendimento. Neste ponto, é possível construir uma definição conseqüente do conceito de beleza. O termo "belo" pode ser entendido como um termo avaliativo genérico, que se aplica para avaliar positivamente um objeto em qualquer circunstância em que o participante da apreciação perceba que esse objeto, funcionando como símbolo com características sintomáticas do estético, age de modo a efetuar distinções relevantes ao cumprimento dos propósitos de uma prática compartilhada. A fim de receber o predicado "belo", um objeto deve funcionar como um símbolo que, precisamente em virtude do seu modo de simbolização, atenda aos seguintes propósitos: (1) viabilize a indivíduos percipientes focalizarem cada vez mais sua atenção e exercitarem seus poderes cognitivos em um alto nível de vivacidade; que, desse modo, (2) promova um processo de reorganização da visão de mundo dos indivíduos a partir do qual ela reapareça sob uma perspectiva inédita; (3) que incite o sentimento do encontro de algo exemplar e definitivo; e (4) que, em razão de cumprir os três itens anteriores, faculte o avanço de uma prática humana compartilhada. Uma definição de beleza somente vem a ser possível como uma definição fenomenológica e que leve em conta os mecanismos da experiência e características gerais de símbolos. Não se deve alimentar a crença na existência de um modo único e explicitamente padronizado pelo qual um objeto é levado a se adequar àqueles critérios e a ser, por conseguinte, classificado como belo; os objetos que se credenciam como alvos de uma correta aplicação do termo o fazem elegendo meios muitos diversificados para a realização das quatro condições mencionadas. Em relação à multiplicidade que se reúne sob o conceito de belo na ciência, afirma Crease:

A beleza dos experimentos [científicos] pode assumir várias formas - assim como a beleza de uma peça de Bach é diferente de uma de Stravinsky. Alguns têm uma beleza sinóptica, resumindo diferentes leis universais, ao passo que outros possuem a beleza da amplitude, juntando elementos em escalas imensamente desiguais. Alguns têm uma beleza austera, seduzindo na simplicidade despojada pela qual revelam a forma pura, enquanto outros são sublimes e nos conquistam ao transmitir sinais do poder terrível, ilimitado, incompreensível e definitivo da natureza. (Crease, p. 14)

O conceito de beleza, sintetiza Crease, "descreve uma sintonia ou ajuste entre um objeto que revela um novo patamar [de conhecimento do mundo] e a nossa 
receptividade para o que é revelado" (Crease, p. 30). A beleza não deve ser entendida como uma qualidade residente em um objeto de modo independente da participação das capacidades perceptivas da mente humana, aplicadas de maneira eficaz; por outro lado, sem que, de seu próprio funcionamento simbólico e em experiência, o objeto esteja préadaptado a elevar a mente a um estágio superior de compreensão e a mantê-la operando em um grau crescente de vivacidade, nada mais poderá torná-lo belo. Nesse caso, então, não encontrando outro respaldo a não ser nas predileções particulares de um indivíduo ou grupo, a atribuição do predicado "belo" ao objeto não se sustenta e se torna fruto de um ato de pura imposição arbitrária. O belo é, portanto, resultado de um compromisso mútuo, solidário, entre sujeito, objeto e uma atividade propositada da qual ambos são parte.

A partir de agora, pretende-se demonstrar que termos e expressões como "beleza" e "apreciação estética" podem ser utilizados no âmbito da ciência com o mesmo direito com que o são nos territórios das artes e da experiência estética da natureza; dizer que se realizou uma apreciação estética de elementos do conhecimento científico não é apenas força de expressão, mas se reveste de um significado preciso que deve ser entendido nas mesmas bases em que se compreende a apreciação estética nas artes. A fim de que as concepções aqui desenvolvidas - em relação ao objeto estético e ao valor estético fundamental a ele associado - possam vir a ser utilizadas a serviço da apreciação estética do conhecimento produzido pelas ciências físicas, é necessário reconhecer de que maneira tais concepções se articulam às avaliações estéticas presentes em relatos que cientistas fazem do seu trabalho. Observar e oferecer uma classificação do conteúdo de tais avaliações será a próxima tarefa a ser empreendida.

\section{A organização de um espaço de apreciação estética no campo dos saberes da física}

A atenção deve estar voltada, neste momento, para as funções simbólicas e modos de referência que objetos estéticos no domínio da física e de outras ciências podem executar. Deve-se observar como a simbolização se comporta em exemplares de conhecimento da física de modo a tornar possível o encaixe entre um exemplar 
específico e a participação apreciativa em um empreendimento compartilhável. Qualquer experiência do valor estético deve estar baseada neste encaixe, quer esteja esse valor corporificado em uma obra de arte, quer em um construto das ciências. $\mathrm{O}$ valor estético mais fundamental advém da intensa auto-realização alcançada quando, em uma atividade investigativa dirigida a determinados aspectos do mundo que se almeja compreender, a atenção dos participantes assinala - naqueles aspectos e nas relações que estabelecem com certos elementos da atividade — a presença de qualidades aptas a despertar e prolongar um modo sinóptico de atividade mental que até então se achava latente no indivíduo. Deste valor básico se originam todos os demais valores estéticos específicos que podem vir a ser encontrados.

O físico Steven Weinberg dá um depoimento que pode ser encarado como paradigmático do fenômeno da apreciação estética na ciência, em particular na física:

Na audição de uma peça musical ou ao ouvir um soneto sente-se às vezes um intenso prazer estético em face do sentimento de que nada na obra poderia ser mudado, que não há uma nota ou palavra sequer que se gostaria que fosse diferente. Em a Família Sagrada de Rafael, a colocação de cada figura na tela é perfeita. De todas as pinturas do mundo, esta pode não ser a sua favorita, mas, conforme se contempla aquela pintura, não há nada que se poderia preferir que Rafael tivesse feito de outra forma. O mesmo é parcialmente verdadeiro (nunca é mais do que parcialmente verdadeiro) a propósito da relatividade geral. Uma vez que você conheça os princípios físicos gerais adotados por Einstein, você compreende que não há nenhuma outra teoria significativamente diferente à qual Einstein poderia ter sido levado. [...] O mesmo senso de inevitabilidade pode ser encontrado (de novo, apenas em parte) em nosso moderno modelo padrão das forças forte e eletrofraca que agem sobre as partículas elementares. (Weinberg, 1996, pp. 110-111, citado por McAllister, 1996, p. 38)

Estas palavras de Weinberg são o relato de um processo em que uma pessoa consegue aprofundar progressivamente a percepção da forma e do conteúdo de idéias científicas até se tornar capaz de discernir o modo como esse encaixe transmite o sentimento da realização de um fim. Neste caso, no andamento de todo o processo, o indivíduo é transportado para um espaço de apreciação clara da alusão que a peça faz ao fato de ser necessária ou inevitável. A veemente alusão de Weinberg à insinuação de um 
sentimento de inevitabilidade é exemplar sob múltiplos aspectos. Em primeiro lugar, no entanto, deve-se examiná-la pela maneira como sugere o estreito vínculo entre a adequação sistêmica que caracteriza uma rede de idéias e propósitos e a beleza que nela se observa. Na vaga percepção intuitiva desta ligação, parecem estar o ponto de partida e a motivação do relacionamento mais intenso e gratificante que alguém pode ter com o conhecimento científico. O que significa precisamente esta adequação?

Aqui, novamente, os instrumentos teóricos desenvolvidos por Goodman são bastante elucidativos. Faria justiça à posição teórica de Goodman se ela fosse condensada por uma expressão como "a busca da eficácia cognitiva na construção de uma versão de mundo", ou algo próximo a isso. Goodman (1978) adota uma postura epistemológica bastante sensata e chã, ao ressaltar que o conhecimento acerca do mundo está fadado a uma dependência direta em relação às versões que o próprio ser humano constrói a fim de conhecê-lo. Descobrimento e invenção se confundem de uma maneira inextrincável no conhecimento humano. A preocupação com o que pode existir de neutro e fundamental subjacente a todas essas versões - cristalizadas nos artefatos das artes, da literatura, da ciência ou mesmo, pode-se dizer, nas construções da percepção ordinária - pondera Goodman, é uma preocupação totalmente vã, pois este "algo que há lá fora" somente pode ser acessado por intermédio daqueles artefatos da mente humana. Talvez se possa ficar sem uma ou outra dessas múltiplas versões, mas sem dúvida não se sabe o que fazer sem nenhuma delas: longe de todas as versões e visões de mundo subsistem apenas o silêncio e a escuridão. Outra constatação de máxima importância é que a confiança na redutibilidade das muitas versões a uma única também logo se vê frustrada antes de ir muito longe. A redução de versões poucas vezes se faz possível. Até mesmo no âmbito da física tem havido dúvidas a respeito da viabilidade de um programa de unificação total. E se não se quiser aceitar que a única forma de conhecimento dotada de legitimidade e fundamento é a de natureza discursiva e descartar, desse modo, toda a produção das artes e da percepção como meras mistificações e engodos, então se depara com uma proliferação de versões de mundo irredutíveis e não traduzíveis entre si, mas sim complementares. Isto fica claro em relação à literatura, por exemplo:

Em um tratado científico, a verdade literal é o que conta mais; mas em um poema ou novela, a verdade metafórica ou alegórica pode ser mais importante, pois mesmo uma sentença literalmente falsa pode ser metaforicamente 
verdadeira e pode marcar ou fazer novas associações e discriminações, alterar ênfases, realizar exclusões e adições. E afirmativas, sejam elas literal ou metaforicamente verdadeiras ou falsas, podem mostrar aquilo que elas não dizem, podem funcionar como exemplos literais ou metafóricos de atributos ou sentimentos não mencionados. (Goodman, 1978, p. 18)

Para inibir a escalada de um relativismo desenfreado frente ao qual verdades e falsidades sejam equivalentes, é preciso divisar critérios de correção, ou de justeza, apropriados aos vários tipos diferentes de versões nas artes e nas ciências: testar a correção de versões e visões de mundo é tudo o que resta ao fim e ao cabo. É aí que entra em ação a noção de adequação pertinente para esclarecer o significado do depoimento de Weinberg. Uma primeira aproximação à idéia geral do que são tais critérios de correção de ajuste - ou de justeza, ou ainda de adequação ou adaptação relevantes para o entendimento da incidência da estética no conhecimento científico se esboça com base nos seguintes comentários que Goodman tece (1978):

Uma sentença é verdadeira, e uma descrição ou representação são corretas, para um mundo a que elas se ajustam [se conformam, se adaptam]. (p. 132)

(...) a verdade de afirmativas e a correção de descrições, representações, exemplificações, expressões - de design, desenho, dicção, ritmo - é fundamentalmente uma questão de adequação: adequação em relação àquilo que é referido de um modo ou outro, ou em relação a outras versões, ou a modos e maneiras de organização. As diferenças entre adequação de uma versão a um mundo, de um mundo a uma versão, de uma versão a si mesma ou a outras versões, se apagam quando se reconhece o papel das versões na confecção dos mundos a que se adaptam. E conhecer ou compreender é visto como se estendendo além da aquisição de crenças verdadeiras para abranger o descobrimento e a invenção de adequações de todos os tipos. (p. 138)

Neste ponto, é preciso tornar a enfatizar que as fontes das quais adequações esteticamente relevantes afloram não podem ser circunscritas ao perímetro dos símbolos sistemáticos generalizados, abstraídos dos significados singulares e encarnados que só o fazer humano produz. Adequações não são capturadas em uma organização meramente gramatical do conhecimento científico, mas devem ser buscadas para lá das distinções que podem resultar do puro relacionamento com os produtos finais e sistematizados da 
ciência. Estes correspondem a um momento apenas inserido em uma prática científica mais básica e ampla. Deve-se ter clareza de que tomar parte em uma experiência do modo como adequações se manifestam na ciência envolve necessariamente estar engajado em uma atividade, em uma forma de envolvimento que por natureza é processual. Na situação de participante de uma busca, a pessoa pode provar significados da adequação intelectual da ciência que se esclarecem à medida que relações - em que entram ingredientes de linguagem e de ação, juntamente com determinados objetos e eventos do mundo - são construídas e experimentadas. Deste modo, o indivíduo se apropria de modos compartilhados de discernir com os quais se torna apto a discriminar relações que promovem de outras que desviam dos pontos de chegada da atividade científica. Tal construção de relações e distinções está, portanto, estreitamente relacionada a fins da ciência que vão sendo reconhecidos na ação, ao longo da participação. Isto serve para ver que um influxo fundamental para o veio da estética da ciência vem dos modos singulares como certas distinções se originam e se desenvolvem no curso de um esforço prático e investigativo orientado para a construção de uma compreensão das regras e procedimentos que conduzem ao cumprimento de propósitos de um ramo do conhecimento científico. Os mecanismos que atuam neste processo são os mesmos que estão em andamento nas artes como base, ao mesmo tempo, para sua produção e sua apreciação. A respeito deles, Dewey faz o seguinte argumento:

Arte é um processo de produção em que materiais naturais são re-modelados em uma projeção para uma realização consumatória por meio da regulação de trens de eventos que ocorrem de um modo menos regulado em níveis mais baixos da natureza. A excelência da arte está na proporção em que fins, os termini finais, dos processos naturais são dominante e conspicuamente desfrutados. Toda arte é instrumental em seu uso de técnicas e meios. Demonstra-se que a experiência artística normal envolve trazer a um melhor equilíbrio do que se encontra em outros lugares, seja na natureza seja na experiência, as fases consumatória e instrumental dos eventos. A arte, desse modo, representa o evento culminante da natureza assim como o clímax da experiência. A esse respeito, a separação nítida que comumente se faz entre arte e ciência é criticada; alega-se que a ciência como método é mais básica que a ciência como conteúdo, e que a investigação científica é uma arte, a um só tempo instrumental em controle e final como um deleite puro da mente. (Dewey, citado por Wickman, p. 19) 
Assim, podem ser discernidos basicamente três aspectos da adequação que se dispõem a ser apreciados ou experimentados em uma versão simbólica integrante da ciência: adequação de superfície, adequação de transparência e adequação entre continuidade e transformação.

1. Adequação de superfície, ou da versão enquanto tal: a capacidade do símbolo de chamar atenção para si mesmo, sua ênfase sobre a excelência de suas propriedades, de seus modos específicos de organização e de seu funcionamento simbólico.

2. Adequação de transparência, ou empírica: a justeza da versão ao abrir uma janela sobre itens de mundo, a revelação que ela promove de uma cascata de similaridades e distinções delicadas e anteriormente ignoradas entre itens de mundo, e a reorganização que isso opera no estado de compreensão sobre o mundo.

3. Adequação da interação do símbolo com outros símbolos antecedentes: consiste no já referido ajuste entre continuidade e transformação. Este ajuste é percebido em duas modalidades: primeiramente, quando símbolos que se referem a partes de experiências prévias são selecionados para serem integrados em uma nova constelação - ou novo símbolo - dando origem a uma totalidade que traz à tona compreensões inovadoras e inesperadas, e que carrega a assinatura de uma revelação e de consumação; em segundo lugar, na interação entre dois ou mais símbolos incidentes sobre o mesmo campo de aplicação, em que um deles surge após outros haverem "conquistado o território". Neste caso, pode surgir uma tensão na qual o símbolo recém-chegado mostra-se dúplice, dividido entre o pólo da inovação que realiza com sua peculiar organização do campo em que incidiu e o pólo da familiaridade, i.é, aquilo que torna sua aplicação àquele campo convincente. Sendo assim, a adequação pode ser percebida no modo pelo qual a tensão é resolvida em um novo e mais profundo patamar de conhecimento: na percepção de uma alternância de papéis em que, ora a formação do novo é influenciada pelo que já estava estruturado previamente ou seja, pelo habitual - ora o novo opera uma reconfiguração do antigo.

Estas não constituem classes puras. Na maioria dos casos de experiências concretas da adequação exibida por um único artefato simbólico do saber científico, a 
forma desta adequação estará agregada simultaneamente a mais de uma das três classes aqui referidas; ou seja, ao analisar um caso específico de um artefato belo, será geralmente constatado que, na qualidade de exemplar da adequação, ele se posiciona na continuidade entre duas, ou mesmo entre as três classes diferentes. Ao lado disso, poderão ser encontradas muitas formas distintas de adequação interagindo de modos complexos no mesmo artefato. Em terminologia técnica, quando uma mesma função simbólica desempenhada pelo artefato apresenta simultaneamente formas de adequação pertencentes a classes distintas, diz-se que as classes do campo de referência não são semanticamente disjuntas no sistema de símbolos de adequação em que aquele artefato se acha inserido. Outra possibilidade é que as adequações pelas quais o artefato responde se distribuam através de funções simbólicas distintas que ele realiza.

Todas as três classes de adequação mostram-se propícias para aumentar o grau de aptidão de um artefato para ser apreciado em percipiência, na medida em que são próprias para promover a focalização da atenção e o aumento progressivo de vivacidade da atividade mental de um indivíduo que entre em contato apreciativo com elas. Primeiramente, a propriedade específica de adequação captura a atenção, salta aos olhos da mente do sujeito que procura por ela: trata-se de uma propriedade referida pelo símbolo mediante a função de exemplificação, quando o artefato constitui uma amostra de algum tipo de adequação. Em segundo lugar, é plausível conjecturar que as classes de adequação acima descritas dispõem os casos particulares desta propriedade em uma distribuição densamente povoada, tal como se fosse um espectro contínuo de níveis: neste sentido, os níveis de adequação se assemelham às medidas de temperatura, para as quais vale que entre duas sempre pode haver uma terceira. Sendo assim, o sistema de símbolos desenhado pelas experiências da adequação em artefatos de ciência ordena estes artefatos em um continuum semanticamente denso. Em terceiro lugar, é esperado que haja um número elevado e heterogêneo de aspectos do símbolo que podem ser pertinentes para a apreciação de sua adequação, em virtude de que, conforme se viu anteriormente, a propriedade de adequação se projeta em no mínimo três classes genéricas distintas. $\mathrm{Na}$ apreciação da propriedade de adequação de um artefato intelectual da ciência, encontram-se, portanto, três das cinco características de modos de simbolização que são apontadas por Goodman como sintomáticas do estético: exemplificação, densidade semântica e saturação. 
Ora, se é verdade que uma teoria, modelo, hipótese ou outra peça de conhecimento científico podem ser denotadas segundo o tipo e o grau de adequação que exemplificam, e que a apreciação da adequação destas peças revela três sintomas do estético, fica então estabelecida a virtualidade, também no plano simbólico-sistemático, da apreciação estética de exemplares de conhecimento científico.

\section{A exemplificação da adequação por meio da adequação da exemplificação no conhecimento produzido pela física}

O aparato conceitual desenvolvido anteriormente e centrado no conceito de adequação nos coloca, agora, em uma posição privilegiada para explicar o caráter propício à apreciação estética de um modelo invocado por uma teoria. Modelos podem funcionar tanto como rótulos quanto como amostras:

Em muitos casos, um modelo é um exemplar ou instância daquilo que modela; o cidadão modelo é um exemplo excelente de cidadania; o modelo do escultor, uma amostra do corpo humano; o modelo de moda, do uso de roupas; uma casa modelo, uma amostra dos oferecimentos de uma construtora; e o modelo de um conjunto de axiomas é um universo coerente com esse conjunto. [meu grifo]

Em outros casos, os papéis são invertidos: o modelo denota, ou tem como um de seus exemplos, aquilo que modela. O carro de um certo modelo pertence a uma certa classe. E um modelo matemático é uma fórmula que se aplica ao processo ou estado ou objeto modelado. O que é modelado é um caso particular daquilo que se encaixa na descrição. (Goodman, 1976, pp. 171-172)

$\mathrm{Na}$ prática científica, por outro lado, modelos não são apenas nem

principalmente modelos de fenômenos, mas sim protótipos cujo modo de funcionamento deve ser observado na sequiência da prática científica. A formação de um paradigma científico pode ser vista como a seleção de exemplares de modos de solução de problemas em um ramo da ciência. Nas investigações em física, a construção de modelos é um expediente utilizado em larga escala, seja a fim de inovar o modo de descrição de um cenário pela substituição de outra descrição ali vigente, seja com o objetivo de estender o sucesso explicativo alcançado em um domínio de fenômenos para 
outro ainda inexplorado. Na segunda hipótese, algumas das propriedades estruturais do modelo que organiza conceitualmente os fenômenos em um domínio de partida são transferidas para a constituição de outro modelo, em um domínio alvo. E em ambos os casos ocorre que um modelo originário, assim que consegue se afirmar, passa a servir de exemplo ou amostra para outro no tocante à posse daquelas propriedades. Outro modo de dizer isso é observar que um modelo que dá origem a uma analogia é membro fundador de uma classe de exemplos de certas propriedades estruturais ou relações entre conceitos. Exemplos desse processo de construção de analogias são encontrados aos montes na física: a analogia do modelo atômico de Rutherford com a mecânica do sistema solar, a analogia óptico-mecânica da Mecânica Quântica de Schrödinger, a analogia entre circuitos elétricos do tipo indutância-capacitância e sistemas mecânicos massa-mola, etc.

Os três tipos de adequação arrolados podem vir a figurar em um modelo conceitual invocado por uma teoria da física. O modelo pode manifestar uma particular adequação do segundo tipo - de transparência - em virtude do modo perspicaz como as propriedades estruturais exemplificadas por ele organizam o domínio de fenômenos sobre o qual a teoria incide. Neste caso, trata-se de uma adequação entre os meios de referência específicos eleitos pelo modelo e os aspectos do mundo por eles referidos e iluminados. Quando a compreensão de um conjunto de fenômenos é guiada por um modelo dotado desse modo de adequação, passa a ser quase impossível discernir os fenômenos em si da sua descrição por meio do modelo, pois a aparência é completamente dominada pelas formas que o modelo lhe confere. Ocorre aí que o modelo dá partida a um processo de ênfase no qual alguns aspectos dos fenômenos se elevam acima dos demais e emergem envoltos em um intenso brilho. Os significados que passam a ser vinculados pelo modelo aos fenômenos que ele descreve são tanto mais aptos a dar suporte a um modo estético de atenção quanto mais esses significados não são apenas descritos pelo modelo, mas são vivamente exemplificados pelos fenômenos. Quando não só o modelo representa os fenômenos, mas, acima disso, as características com as quais ele os representa são mostradas, exibidas de um modo singularmente adequado em ocorrências deles, tem-se um caso de exemplificação do modelo pelo fenômeno. Esta exemplificação tem um alto grau de adequação, e sua apreciação é carregada pela expectativa de conduzir a uma intensa realização. De outra maneira, dir-se-ia que, quando a percepção apreende de um modo vivo o grau elevado 
com que a adequação se materializa na exemplificação por um modelo, este modelo exprime um senso de inevitabilidade, ou, na terminologia de Goodman, exemplifica a inevitabilidade. Assim, um modelo teórico-conceitual da física pode exprimir inevitabilidade da mesma forma que uma pintura pode exprimir paixão, ou uma música exprimir nobreza. A isto precisamente é que Weinberg está se referindo na passagem acima.

O mesmo senso também pode ser flagrado em experimentos projetados meticulosamente para testar as conseqüências de uma hipótese audaciosa e dar um sinal inequívoco de sua eficácia explicativa. Um episódio notável em que a exemplificação de um modelo por um experimento se manifestou com grande brilho é reportado pelo historiador da ciência Robert Crease (2006). Crease conta de sua entrevista com Sheldon Glashow - um dos autores do modelo padrão das interações fundamentais ao lado de Abdus Salam e do próprio Steven Weinberg - em que Glashow descreve a ocasião da vindicação do modelo por meio do experimento das correntes neutras violadoras de paridade, realizado em 1978 no laboratório SLAC na Califórnia. O efeito a ser observado de acordo com a teoria - uma diferença no modo como elétrons em diferentes estados de polarização são espalhados por alvos de prótons - era algo absolutamente diminuto e difícil de ser detectado. Raciocinando em termos do modelo padrão, no entanto, uma equipe numerosa de cientistas e engenheiros planejou um experimento de enorme complexidade que culminou, após um esforço de nove anos, com a observação dos eventos exatamente conforme previstos pelo modelo. Diante de Crease, Glashow rememorava os fatos daquela ocasião, e, em determinado momento, assumindo uma atitude enfática, exclamou: "Aquele foi um experimento belo, um experimento absolutamente belo!” (Crease, 2006, p. 9). Fica patente neste episódio o sentido da afirmação de Goodman de que "o modelo de um conjunto de axiomas é um universo coerente com esse conjunto". O que isto quer dizer é que há ocasiões em que o que é observado se encaixa tão perfeitamente a um modo de descrição que, depois de apreciá-lo por seu intermédio, se torna extremamente difícil perceber o fenômeno a não ser como a assinatura de elementos estruturais daquela particular descrição. Comenta Crease (p. 10): "De fato, o experimento executado de maneira tão magistral fez a existência de uma nova e fundamental propriedade da natureza - as correntes neutras violadoras de paridade - tão vividamente aparente para qualquer pessoa com treinamento em física que até mesmo aqueles que não participaram do projeto o 
acharam emocionante" (meu grifo). Nos graus mais elevados desse modo da adequação, uma apreciação bem-sucedida pode até mesmo conduzir o aspecto representacional do modelo a recuar para a periferia da atenção, que fica tomada quase por inteiro pelos atributos proeminentes do artefato simbólico abstrato. Em suma, a qualidade estética fruída na experiência apreciativa de um modelo físico dotado de um alto grau de adequação do primeiro e do segundo tipos é devida à percepção da manifestação das propriedades estruturais do modelo nos fenômenos por ele descritos. Conseqüentemente, uma ocorrência do fenômeno é convertida em uma amostra concreta daquelas propriedades às quais o modelo chama atenção. Em poucas palavras, este modo da adequação poderia ser descrito do seguinte modo: não só a descrição dos fenômenos pelo modelo, mas principalmente a exemplificação do modelo pelos fenômenos. Ao lado disso, na medida em que uma analogia é invocada para dar forma a outro domínio fenomenológico, a percepção do compartilhamento das mesmas relações conceituais por fenômenos anteriormente considerados de naturezas independentes se acrescenta ao valor estético experienciado na apreciação de um modelo. Este é o sentido do atributo de 'uniformidade em meio à diversidade' que, segundo Hutcheson, é o alicerce da beleza intelectual.

No primeiro modo da adequação da simbolização mencionado, o símbolo impõe-se pelas suas características de superfície. A transparência do símbolo é reduzida ou, melhor dizendo, os elementos de mundo referidos por seu intermédio ocupam um espaço menor da atenção, monopolizada pela justeza e finura das características do modo de funcionamento do símbolo. Este modo da adequação também pode se fazer presente em modelos de fenômenos físicos, sobretudo aqueles de alto grau de abstração. Na história da ciência, a apreciação da adequação de modelos e teorias enquanto símbolos em si mesmos, isto é, pela qualidade de sua forma específica de operação simbólica, é tipificada pela figura do físico francês Pierre Duhem:

É impossível seguir a marcha de uma das grandes teorias da física, vê-la desenrolar majestosamente suas deduções regulares partindo de hipóteses iniciais, ver suas consequiências representarem uma multitude de leis experimentais descendo até o mínimo detalhe, sem ser encantado pela beleza de uma construção como essa, sem sentir com agudeza que tal criação da mente humana é verdadeiramente uma obra de arte. (Duhem, 1906, pp. 69-104, citado por McAllister, 1996, p. 52) 
No entanto, no acervo das reflexões literárias sobre o valor estético do conhecimento científico, dificilmente se poderá encontrar um exemplo mais apto e arrebatador que a metáfora de Boltzmann, acerca de sua experiência da beleza do formalismo de Maxwell na teoria cinética dos gases:

Assim como um músico pode reconhecer seu Mozart, Beethoven ou Schubert após ouvir os primeiros acordes, também um matemático pode reconhecer seu Cauchy, Gauss, Jacobi ou Kirchhoff logo nas primeiras páginas. Os escritores franceses revelam-se por sua extrema elegância formal, ao passo que os ingleses, especialmente Maxwell, por seu senso dramático. De quem, por exemplo, não serão conhecidas as memórias de Maxwell sobre sua teoria dinâmica dos gases?... As variações das velocidades são, a princípio, desenvolvidas majestosamente; então de um lado entram as equações de estado; e do outro lado, as equações de movimento em um campo central. Ainda mais alto ruge o caos de fórmulas. De repente, ouvimos, como de tímpanos, as quatro batidas 'faça $\mathrm{n}=5$ '. O mau espírito $\mathrm{V}$ (a velocidade relativa das duas moléculas) desaparece; e, do mesmo modo em que na música uma nota até então dominante no baixo é repentinamente silenciada, aquilo que tinha parecido insuperável foi vencido como por um passe de mágica. ...Ainda não é o momento de perguntar o porquê dessa ou daquela substituição. Se você não for arrebatado com o desenvolvimento ponha o trabalho de lado. Maxwell não escreve música de programa com notas explicativas... Um resultado após o outro segue-se em rápida sucessão até que ao final, como o clímax inesperado, chegamos às condições para o equilíbrio térmico juntamente com as expressões para os coeficientes de transporte. O pano então cai! (Boltzmann, citado por Chandrasekhar, 1987, p. 53)

As teorias e modelos a que Duhem se reporta, e dos quais Boltzmann dá um exemplo magnífico de narração de experiência, são aqueles que enfatizam a estrutura lógicomatemática dos seus raciocínios e métodos. Um exemplo dessa atitude de apreciação de teorias abstratas é dado pelo francês Joseph Louis Lagrange. Com sua obra Mécanique Analytique de 1788, Lagrange articula a mecânica newtoniana no final do século XVIII, estendendo o poder de solução de quebra-cabeças do paradigma de modo a abranger problemas que aguardavam pela introdução de um aparato matemático à altura. No prefácio, Lagrange demonstra seu orgulho pela total independência de seu método em 
relação à necessidade de mecanismos visualizáveis, destacando-o pelas qualidades estéticas de sobriedade, regularidade e uniformidade:

Não serão encontradas figuras nesta obra. Os métodos que eu aqui exponho não requerem construções tampouco argumentos mecânicos ou geométricos, mas somente operações algébricas, sujeitas a um procedimento regular e uniforme. (Lagrange, 1788: xi-xii, citado por McAllister, 1996, p. 52)

A apreciação da corporificação deste modo da adequação em uma teoria guarda um estreito parentesco com a apreciação de poemas, e mesmo com obras de arte ainda mais abstratas como a música instrumental, ao contrário do que sugere Osborne no trecho a seguir:

O veículo material não se torna inteiramente "transparente" - perdido para a observação, mas contribui para a impressão total. Assim também, quando lemos um artigo de jornal ou um folheto científico atentamos para o significado das frases e não notamos as palavras (podemos até não perceber a linguagem em que estão escritos); mas, quando lemos poesia, as palavras cessam de ser inteiramente "transparentes", são notadas por direito próprio - seu som, ritmo, personalidade, associações impõem-se à atenção em certa medida, mesmo quando os significados brilham através delas, e têm uma substância sensorial própria. (Osborne, 1978, p. 182)

O que Osborne deixa escapar é que boa parte das "palavras" que tipicamente comparecem em um trabalho científico são mais do que meros rótulos com os quais o assunto enfocado é revestido. Pode-se manter com elas uma relação carnal, pois são o próprio tecido do domínio que elas ordenam, sem o que certos aspectos do mundo deixam de ter substância. Parece ter sido este o sentido que Bachelard quis transmitir quando falou da realização do matemático que acompanha a matematização do real na física do século XX. O processo de simbolização é constitutivo da matéria que ele traz à tona, e não apenas forma que poderia ser alterada sem modificar também o conteúdo. Os conceitos de uma teoria são convocados para desempenhar o papel de matéria-prima conceitual da qual se edifica uma estrutura de pensamento, que é a estrutura do próprio mundo construído pela teoria. Dessa forma, não são simples predicados avulsos, porém atuam solidariamente ao lado de outros conceitos, formando cadeias, redes, formas que sensibilizam pela maneira de sua configuração. Atenta-se para eles principalmente pelas 
relações que mantêm entre si: contrastes, variações, similaridades, simetrias, combinações, atrações, repulsões, tensões e resoluções (Goldman, 1990, p. 28). As estruturas criadas mediante essas relações são os conteúdos capturados durante uma apreciação estética de teorias e modelos abstratos, mas também de certos experimentos concretos, descritos como dinâmicos, compactos, equilibrados, harmoniosos, internamente coerentes, elegantes. $\mathrm{Na}$ apreciação de exemplares de conhecimento da física, portanto, é correto dizer que "é preciso ter um olho no gato e outro na lebre". Uma atenção estética plenamente desenvolvida é capaz aí de trabalhar, ao mesmo tempo, com a transparência e com a opacidade do seu objeto, de combinar, em uma apreensão unificada, aspectos de profundidade - a representação da parcela de mundo enfocada - com características de superfície - as características imanentes ao modo de simbolização com que a teoria ajuda a construir o seu mundo. Conforme observa Jardine:

(...) as qualidades estéticas mais significativas são precisamente aquelas cuja percepção demanda essa espécie de reconciliação [entre percepções de aspectos opostos] na experiência perceptual. A qualidade vívida da pintura de Cézanne jaz na maravilhosa integração de superfície e conteúdo; as obras-primas religiosas e mitológicas de Poussin são esplêndidas em sua austeridade suntuosa; e a grandiosidade que Darwin viu no emaranhamento do recife não está nem no seu aspecto cruel, dominado pela morte, nem em seu aspecto sereno, transbordante de vida, mas em uma visão que reconciliava os dois. (Jardine, 1991, pp. 223).

\section{A adequação observada na incidência da metáfora em exemplares de conhecimento da física}

A análise do recurso que se faz à metáfora em certos momentos do processo de transformação do conhecimento científico é extremamente propícia para observar o caráter da terceira espécie de adequação identificada anteriormente. Assim como acontece na percepção das sutilezas que podem ser encontradas em obras de arte, também na investigação do mundo físico tateiam-se aspectos fugidios que escapam totalmente às tentativas da linguagem para capturá-los. Há um hiato irredutível entre a 
extensão referencial que conceitos lingüísticos conseguem recobrir e as facetas diversas do mundo que podem responder por algum tipo de manifestação. Muitos são os procedimentos de que se pode lançar mão a fim de diminuir os efeitos da carência da linguagem e ampliar o poder de categorização sobre aquilo que não se deixa apreender completamente pelo discurso. Seguindo Goodman, é possível caracterizar tais procedimentos enquanto meios com que se constroem mundos novos a partir do rearranjo de outros mundos preexistentes. A simbolização metafórica é um deles. A metáfora tem como um de seus méritos a capacidade de estabelecer uma mediação entre o que pode ser dito e o impresentificável. Como força que se defronta diretamente com o desafio de auscultar o inefável, a ciência não poderia ter ficado indiferente a essa qualidade de interligação que a metáfora exibe. Sendo assim, a atividade científica reconheceu nela um grande potencial heurístico. Carregado por ela, o pensamento ordenador avança para dentro do terreno do indizível. Por outro lado, o uso da metáfora na ciência está intimamente ligado à aptidão que determinados cientistas manifestam para o manejo de imagens mentais como veículos da sua teorização. Por meio dela, esses cientistas podem contar com mecanismos para representar pictórica e imaginativamente um domínio de fenômenos. Em razão disso, a metáfora traz também consigo a qualidade de visualização (McAllister, 1996, pp. 48-54). Precisamente no papel que a visualização possui como atributo inerente à metáfora reside a diferença básica desta para a modelização, examinada anteriormente.

Um excelente exemplo de como a metáfora incide para a criação de imagens mentais de comportamentos do mundo físico é a concepção de campo eletromagnético introduzida por Faraday (ver McAllister, pp. 53-54). Antes de a compreensão dos fenômenos eletromagnéticos ter sido colonizada pela noção de campo, a interação entre corpos carregados era implementada por meio de uma abordagem inteiramente matemática, centrada no conceito de potencial. De modo coerente com essa abordagem, predominava a idéia de que uma carga elétrica atua sobre outra de maneira direta, havendo a transmissão instantânea da influência, sem nenhuma participação do meio entre elas. Com sua metáfora do campo, Faraday inicia uma campanha para confrontar e destituir, aos poucos, o poderio das forças de ação à distância sobre o território do eletromagnetismo. O domínio sofreria, assim, a invasão de hostes de rótulos provenientes de territórios estrangeiros. Contudo, a conquista do novo território pelos rótulos invasores não se faz com base na força bruta: 
A força metafórica exige uma combinação de inovação com encaixe, do estranho com o óbvio. A boa metáfora satisfaz ao mesmo tempo em que surpreende. A metáfora é mais potente quando [a família de rótulos] transferida realiza uma nova e notável organização e não uma mera renomeação de uma organização velha. (...) onde [com a emigração de uma família de rótulos para um novo domínio] resulta uma organização inusitada, novas associações e discriminações são também feitas dentro do domínio de transferência; e o efeito que a metáfora produz é tanto mais poderoso quanto mais tais associações e discriminações são intrigantes e significativas. (Goodman, 1976, pp. 79-80)

A imagem a seguir por intermédio da qual Hans Christian Oersted se põe a explorar a noção nascente de campo eletromagnético - tomando por base o termo conflito e outros rótulos a ele associados, como ímpeto, luta e resistência - oferece uma ótima oportunidade para observar a característica de estranheza presente ao convocar para uma nova aplicação rótulos que já possuem um uso antecedente consagrado pelo hábito:

O conflito elétrico atua apenas sobre as partículas magnéticas da matéria. Todos os corpos não-magnéticos parecem penetráveis pelo conflito elétrico, enquanto os corpos magnéticos, ou melhor, suas partículas magnéticas, opõem resistência à passagem desse conflito. Por conseguinte, podem ser movidas pelo ímpeto das forças em luta. (citado por Cole, p. 35)

Para não serem expulsos, é indispensável, portanto, que os novos rótulos saibam demonstrar suas virtudes de classificação e organização aos governados. Seu poder sobre eles deve advir de uma autoridade consentida. Deve-se então fazer a pergunta: como a descrição dos fenômenos eletromagnéticos pode extrair algum benefício das sugestões e alusões feitas pelo termo "campo"? De onde vem a força da metáfora de campo eletromagnético?

Campo logo suscita à mente uma oposição a cidade. Na Europa do século XIX, podem-se imaginar as cidades como centros de onde se irradia a força da atividade industrial e comercial e que estão separados uns dos outros por vastos espaços rarefeitos. Os campos são este espaço circundante e intermediário entre as cidades, através do qual circulam mercadores e mensageiros, ladrões e viajantes. Cumprem um papel importante como rotas comerciais por meio das quais as cidades trocam 
mercadorias e se influenciam mutuamente. Trata-se também de lugares misteriosos, em que algo pode sobrevir a qualquer momento: dada a complexidade das rotas e os perigos que espreitam ao longo das múltiplas estradas, veredas e trilhas que correm através deles, os campos necessitam ser mapeados. No mesmo sentido, o campo é ainda o campo de batalha, palco dinâmico de lutas e de definição de estratégias. Todos estes significados habitualmente relacionados com a palavra campo são assim exportados para gerar mecanismos de apoio ao pensamento na investigação do eletromagnetismo. Após a invocação da idéia de campo, onde anteriormente o que se notava era apenas a distância entre os corpos carregados, passou a figurar uma família inteira de rótulos comumente usados para fazer referência a atributos relativos a espaço, a tempo e a relações de causa e efeito: contínuo, inomogêneo, espalhado, interveniente, circundante, intermediário, que flui, que permeia, que mapeia, que induz, que interliga, que propaga, rarefeito, diáfano, imaterial, virtual, uniforme, divergente, rotacional, variável, que vibra, oscilante, retardado, polarizado, transversal, longitudinal, descontínuo, localizado, imediato, estacionário, isotrópico, pictórico, real, etc. Um dos aspectos desta transferência de rótulos é o sentimento que ela confere ao investigador de que agora se tornou possível se aproximar de um território resistente à assimilação discursiva: abrese a perspectiva de observar um domínio obscuro com um certo ar de familiaridade e segurança. Porém, apenas a familiaridade é insuficiente para garantir a adequação e, por conseguinte, a força e o interesse da metáfora de campo. A fim de demonstrar a sua força, ela precisa mostrar-se apta a entreabrir ao intelecto um panorama pleno de visões novas e inesperadas. Devem entrar em ação suas virtudes de visualização. Graças à interação entre, de um lado, a disponibilidade de conceitos manipuláveis em virtude de suas associações habituais e, de outro, o modo penetrante e inovador de ordenação que sua manipulação traz para o domínio receptor, surge a capacidade de descortinar ao pensamento um percurso riquíssimo de exploração. Assim, de uma combinação particularmente feliz de rendição ao hábito e associações férteis, o uso da metáfora de campo no eletromagnetismo vai desaguar na desmaterialização da visão do universo. A princípio, aplicar a idéia de campo a fenômenos de natureza elétrica e magnética passa a ser visto ao mesmo tempo como estranho e familiar. Os fenômenos cedem à aplicação dos rótulos associados ao termo campo ao mesmo tempo em que também resistem a ela. Por um lado dizem “não se aplica”, e, por outro, "sim, se aplica!". Porém, este é um caso em que, em virtude do poder explicativo demonstrado pela aplicação metafórica, a atração vence a resistência (Goodman, 1976, pp. 68-71). Ao aceitar trilhar o percurso a 
que o conceito de campo convida, o olhar vai assinalando símiles e distinções curiosíssimas e se admirando: a luz que se avista de uma estrela no firmamento noturno não são espumas flutuantes no mar etéreo, mas a fuga da energia que deixou a rotina material para dar um passeio pelo campo!

Neste processo, também ocorrem mudanças significativas no domínio de origem dos termos recém-chegados. Todo um potencial desconhecido destes termos se revela assim que adentram o novo domínio. Por exemplo, em uma frase como "o mapa mundi mostra a polarização das nações sob a ação do campo de forças de duas nações hegemônicas", em que ocorre uma reversão no sentido da transferência metafórica e a descrição de uma configuração geopolítica passa a ser guiada por uma comparação com o estado do dielétrico entre as placas com cargas opostas de um capacitor. Assim, os territórios relacionados pela transferência de rótulos se associam e se iluminam mutuamente, num trajeto de ida e volta. Em suma, a aplicação de uma imagem a um domínio ao qual ela originalmente não pertencia desencadeia um conflito envolvendo, de um lado, a sua novidade, e de outro, a sua familiaridade. Diz Goodman: "existem ao mesmo tempo afastamento e observância do precedente" (1976, p. 71). O modo engenhoso e surpreendente em que tal conflito se resolve ocasionando uma reconfiguração das formas de classificação do mundo anteriormente validadas constitui uma fonte importante para a apreciação da adequação na atividade científica. Talvez se possa falar, no momento em que a conquista de um novo território por rótulos provenientes de outro está completa, que se consumou a superação de um obstáculo ao mesmo tempo estético e cognitivo. 


\section{Uma analogia para compreender o processo da experiência estética no ensino de física}

O objeto estético significa - ele é belo com a condição de significar - certa relação do mundo com a subjetividade, uma dimensão do mundo; ele não me propõe uma verdade a respeito do mundo, ele me descortina o mundo como fonte de verdade. Pois o mundo não é, para mim, um objeto de saber antes de ser um objeto de deslumbramento e de reconhecimento. (...) O objeto estético resume e exprime numa qualidade afetiva inexprimível a totalidade sintética do mundo: ele me faz compreender o mundo ao compreendê-lo em si mesmo, e é através de sua mediação que eu o reconheço antes de conhecê-lo e que eu nele me reencontro antes de me ter encontrado.

Mikel Dufrenne ${ }^{6}$

\section{A natureza dos exemplares de conhecimento científico enquanto objetos para a apreciação estética}

No capítulo anterior, o interesse da investigação esteve voltado para lançar luz sobre o sentido de apreciar esteticamente os construtos simbólicos da ciência. Como resultado, foi possível identificar nos exemplares de conhecimento produzidos pela atividade científica a presença de alguns sintomas do estético, em conformidade com a abordagem de Goodman. Trata-se, como se observou, das mesmas classes de sintomas que Goodman afirma se manifestarem em todas as formas de arte. Na ciência física, porém, eles são observados como elementos constitutivos da qualidade estética peculiar exibida por suas idéias e experimentos, a saber, a qualidade de adequação ou justeza de encaixe. Desse modo, foram encontradas indicações sólidas e precisas da existência de

\footnotetext{
${ }^{6}$ DUFRENNE (2004), p. 53.
} 
um espaço estético no domínio da ciência, e examinados alguns exemplos particulares que atestam, de uma vez por todas, o direito a falar nos exemplares de conhecimento científico como veículos legítimos para a apreciação estética. A apreciação estética de elementos do conhecimento da física possui, portanto, um paralelismo estreito com a atitude apreciativa dirigida a obras de arte. Uma vez tendo sido estabelecida a concepção da apreciação estética da ciência em bases coerentes, tem-se agora oportunidade para dar um passo adicional. Assim, o presente capítulo tem como objetivo dar visibilidade para alguns princípios de seleção e organização do conhecimento físico que podem orientar, no ensino de física, a criação de estratégias adequadas à finalidade da percepção das qualidades estéticas implícitas nesta ciência. Em vista disso, as questões que passarão a ser examinadas agora são as seguintes:

- Que critérios podem guiar o processamento do acervo da ciência tendo em vista a especificação e compilação de exemplares adequados à apreciação estética?

- Como definir uma peça de conhecimento científico apta à apreciação?

- Que tipo de seleção, organização e mediação do conhecimento científico a apreciação estética supõe?

De início, tome-se como referência a apreciação de obras de arte. Deve-se ter em mente que cada espécie diferente de arte e de objeto estético tem uma natureza própria, o que importa em características e modos distintos para o processo de apreciação. Osborne (1978, p. 174) divide as formas de arte em três grupos de acordo com o grau de intimidade de sua associação com um suporte físico. O primeiro grupo é o das artes em que as obras produzidas têm um vínculo estreito com um objeto material - um substrato físico, como denomina Roman Ingarden - cujos exemplos típicos são a pintura e a escultura. Em seguida vêm as artes que se centram em performances baseadas em um registro escrito, de que são exemplos a música e a poesia. Nelas, a ligação entre a entidade que efetivamente tendemos a pensar como sendo a obra e o registro material correspondente é bem mais remota. E finalmente aparecem as artes de performance que não se baseiam em um registro escrito, como a dança, a poesia oral, as canções folclóricas e certos rituais tradicionais de caráter estético, que não possuem substrato nem registro material.

Em face de uma classificação desse tipo, levanta-se de imediato uma questão relativa ao caráter do conhecimento científico enquanto objeto para a apreciação 
estética. Em primeiro lugar, não há um veículo único por meio do qual a mediação dos saberes da ciência esteja obrigada a acontecer. Textos didáticos, exposições dialogadas, animações computacionais, maquetes, demonstrações experimentais ou observações de ocorrências de um fenômeno na natureza ou em um museu de ciências podem em princípio funcionar como símbolos de parcelas desse conhecimento, e quanto mais desses símbolos estiverem disponíveis para atenção, mais rica e completa poderá ser a idéia constituída a respeito dos significados dos exemplares da ciência. Por outro lado, entretanto, no relacionamento que se estabelece com as idéias da ciência por intermédio de um desses veículos em particular, não é legítimo identificar integralmente o símbolo em questão com aquilo que se presume ser o sentido final da ciência. Na incompreensão deste ponto se localiza um obstáculo superlativo no caminho da progressão da aprendizagem do significado da ciência, nas escolas e também na sociedade. Embora Foucault tenha construído pêndulos, seu interesse último não reside completamente no movimento curioso mostrado por eles, tampouco em sua utilização tecnológica, mas na interpretação que traz à tona uma relação entre o movimento observado e a rotação da Terra em torno de seu próprio eixo. E conquanto um professor de ciências lecione uma disciplina, o foco principal não recai (ao menos não deveria recair) sobre as condutas, procedimentos e acordos que presidem o andamento da mesma, mas sobre as compreensões e habilidades que se pode vir a formar ao participar dela. De maneira mais ou menos explícita, quem de fato aprecia a ciência, mediante o contato com um texto, uma palestra ou um experimento, reconhece que há um sistema especial de símbolos em que esses elementos estão inseridos e pelo qual são governados. A maneira correta de considerar um desses elementos envolve enxergá-los como veículos dos quais a ciência (ou a educação em ciências) lança mão para fins de simbolização de seus conceitos e idéias. O modo de funcionamento dos símbolos definido pelo sistema em que estão situados, e as associações, discriminações e generalizações que decorrem precisamente dessa operação referencial sobre certos elementos do mundo - estes são os verdadeiros objetos colimados quando a atenção se volta para um dos meios mencionados anteriormente. Sendo assim, o significado total de um artefato simbólico da ciência não se constitui por inteiro em uma única experiência singular do mesmo, mediada por um único contexto concreto; a integração deste significado é um processo de construção progressiva de uma entidade que se torna mais apurada mediante a combinação deliberada e criativa de muitas experiências distintas do mesmo artefato. Com base no contato mantido com símbolos intersubjetivos diversos que fazem 
referência a essa entidade em múltiplas ocasiões de engajamento, cada indivíduo participante poderá compor e compartilhar uma noção do que ela é. Muitos processos de experiência singulares devem ser tramados em direção a consumar uma unidade bem delimitada e bem compreendida de saber científico. A chave que abre caminho para a construção de uma interpretação coerente da natureza do conhecimento científico como objeto de apreciação estética encontra-se exatamente aí. Considere-se o que Osborne diz acerca do caráter da obra nas artes de performance:

Esta obra de arte à qual performances individuais estão nocionalmente relacionadas nunca está concretamente presente na experiência de ninguém. A concepção que a maior parte das pessoas dela tem é um conjunto construído de grande número de performances reunidas. Entretanto, o registro pode também servir em certo sentido como norma e dela um entendido experimentado pode obter uma noção do que seria uma performance ideal. Não é tolice um homem dizer que nunca ouviu uma performance completamente satisfatória de tal ou qual composição musical ou dizer de determinada performance que foi errada ou infiel à obra de arte.

Nas artes literárias a importância da performance é mínima. A apreciação consiste essencialmente na apreensão de uma síntese mental de significados verbalizados registrados. (Osborne, 1978, p. 174)

Vê-se com toda clareza neste comentário a relevância da comparação entre peças de conhecimento científico e peças musicais e literárias em se tratando de exigências impostas à apreciação. Está em evidência aqui o princípio de que a apreciação estética é uma aptidão cognitiva: conforme já se afirmou, apreciar é desenvolver uma capacidade de direcionar a atenção para as características de um objeto complexo e deixá-la ser absorvida e expandida vivamente por elas. É certo que a apreciação estética no âmbito da música tem início com a audição - e, portanto, com a apresentação aos sentidos de um objeto perceptual correspondente a certos estímulos físicos. Deve-se, no entanto, ter a compreensão de que ela não se esgota no material sonoro concreto. O conteúdo de uma performance musical apta à apreciação ultrapassa a captação sensorial e direta dos sons em que ela se constitui, pela razão de que a performance é também um símbolo que remete a algo que não está diretamente presente aos sentidos. Este algo é a obra musical. Assim, da conjugação entre: (1) o caráter abstrato da obra musical; e (2) a 
natureza cognitiva da apreciação, depreende-se que apreciar uma obra como uma sonata de Beethoven envolve construir uma compreensão do valor e da excelência de uma entidade abstrata e complexa. Para chegar lá, o apreciador necessitará ouvir diversas execuções da obra por diferentes intérpretes, em que cada um deles saiba proporcionar uma particular concepção geral da obra ao mesmo tempo em que eleger uns e não outros aspectos dela para enfatizar e trazer à atenção do ouvinte. Do mesmo modo, por mais que a prova de um teorema ou a arquitetura de um modelo científico possam ser registrados e materializados em um objeto ou evento particulares, sua substância não é esgotada neste objeto ou evento, que funcionam mais como guias para a construção pelo indivíduo de uma noção do que seja o sentido integral de um subconjunto determinado do saber científico. Ao ter contato com muitos veículos diversificados que conduzem mais ou menos para o mesmo perímetro do continente de abstrações da ciência, o indivíduo constrói uma combinação dos aportes de cada símbolo dentro das linhas mestras demarcadas por eles, tramando uma compreensão global e pessoal daquele perímetro. Portanto, do ponto de vista da apreciação, os elementos do saber da ciência podem ser situados em uma posição intermediária entre as obras musicais e as literárias, apresentando pontos de aproximação e de afastamento em relação a ambas: aproximamse, de um lado, das obras literárias, no sentido de que a apreciação destas demanda a habilidade de contemplar a paisagem de significado que se deixa ver através das palavras, como se fora através de uma janela; afastam-se delas, de outro, no que toca à unicidade do veículo que abre a janela - a combinação única e bem definida de caracteres que define a identidade de um romance ou uma poesia particulares. Inversamente, estão próximos das obras de música na medida em que a identidade do elemento de conhecimento científico, assim como a identidade de uma obra musical, convive com a multiplicidade de seus exemplos concretos - algo que ocorre, por exemplo, nas múltiplas possibilidades de realização de um mesmo experimento científico; e, ao mesmo tempo, contrastam com elas em virtude da transparência que se faz presente em teorias e modelos na ciência, mas não na música. Como um modelo aproximado, faz sentido, portanto, definir peças de conhecimento científico; desse modo, o processo pelo qual a apreciação estética se dá na ciência pode ser compreendido segundo um modelo com estrutura análoga a da apreciação de peças musicais: textos, aulas, demonstrações, visualizações, etc. estão para as peças de conhecimento científico assim como as performances estão para a obra musical. O elo que liga em definitivo a compreensão do mecanismo da apreciação estética na ciência 
com a apreciação de obras de arte acha-se na relação existente entre obra e performance nas artes que se baseiam em performances reguladas por um registro. Nas próximas seções, o significado do conceito de peça de conhecimento científico será articulado e suas consequiências para a especificação de instrumentos e estratégias no ensino de física serão exploradas.

\section{Esboço geral da teoria da notação de Goodman}

Uma vez tendo sido demonstradas as similaridades entre os campos de apreciação da arte musical e da ciência, será então possível ver com nitidez as conseqüências que elas acarretam para a organização de estratégias de ensino-aprendizagem da física voltadas para a percepção das qualidades estéticas da ciência. A teoria da notação de Goodman é o elemento que confere estrutura ao modelo que vai ser desenvolvido, provendo o quadro dos conceitos com auxílio dos quais a analogia é edificada.

A indagação que está na raiz da teoria dos sistemas notacionais desenvolvida por Goodman (1976, capítulos IV e V) se localiza no problema da identidade de obras de arte alográficas, i.e., obras de arte que não estão confinadas a um original único e a uma história de produção, mas que consistem em um conjunto de orientações gerais que existem para serem seguidas por um número qualquer de intérpretes que podem vir a participar da criação de exemplos dessa obra. A música é o protótipo de arte alográfica, e o cerne do problema está na seguinte constatação: uma peça musical abre espaço para um número praticamente ilimitado de performances que a exemplificam legitimamente e, ao mesmo tempo, em meio às significativas variações que vão acontecendo na passagem de uma performance para outra, ainda é possível reconhecer que se trata da mesma obra. Há inúmeras situações como esta em que se consolidou na prática o hábito de pensar em um conceito abstrato único coligando uma infinidade de exemplos distintos. No caso da música, entretanto, a exigência vai além: não é suficiente que exista o conceito da obra definindo se uma performance particular é ou não membro de sua classe de exemplos. É necessário também que, no sentido oposto, partindo de uma dessas performances, seja possível retornar para o mesmo conceito que a definiu. 
Goodman salienta que esta é uma condição bastante especial, que não costuma ser satisfeita nas definições que são manipuladas na grande maioria das situações comuns:

Enquanto que uma boa definição sempre determina inequivocamente que objetos se conformam a ela, uma definição raramente é univocamente determinada por cada um de seus exemplos. Se aponto para um objeto e pergunto a você que tipo de objeto é, você pode dar uma ampla variedade de respostas, escolhendo qualquer classe a qual o objeto pertença. De acordo com isso, ao passar alternadamente (e corretamente) de um objeto para uma definição - ou predicado ou outro rótulo - com a qual o objeto está de acordo (p. ex., o rótulo "mesa" ou algum termo coextensivo), em seguida para outro objeto (p. ex., uma mesa de aço), para outro rótulo (p. ex., "coisa de aço") aplicável ao segundo objeto, e para um terceiro objeto (p. ex., um automóvel) que concorda com o segundo rótulo, podemos passar de um objeto para outro de tal maneira que nenhum rótulo na série se aplica a ambos; e dois rótulos na série podem diferir totalmente em extensão, sem haver um objeto sequer concordante com ambas. (Goodman, 1976, p. 129)

Dentro de seu programa de compreender todo o conhecimento humano como resultado de operações de símbolos alocados em sistemas diversos, Goodman considera que uma peça musical está inserida em um sistema de símbolos musicais: um choro de Pixinguinha, por exemplo, está inserido no sistema de símbolos de características bem definidas da música ocidental. Esse sistema pode ser visto como definindo um processo de produção de classes de exemplos concretos a partir dos caracteres contidos no sistema. Nele, a partitura se localiza no plano sintático, assumindo a posição de um caractere composto de onde parte a função de referência. Já as performances estão no plano semântico: são os itens a que um determinado caractere faz referência. As performances se reúnem em classes segundo o critério do pertencimento a uma mesma obra. Portanto, afirma Goodman, uma dada obra musical pode ser definida como uma classe de performances concordantes com uma partitura (Goodman, 1976, cap. IV). É a partitura que irá regular a identificação da mesma obra através das variações que ocorrem ao passar de uma performance a outra. Note-se que a partitura não precisa ter sido escrita originalmente; a simples instância de existir um sistema de símbolos musicais em operação é suficiente para que a definição unívoca da obra possa ser feita. 
Para ver como a definição unívoca é possível, Goodman parte então em busca de um conjunto mínimo de condições que devem ser atendidas por um dado sistema de símbolos para que ele se torne um sistema notacional (ou notação), e desse modo, permita uma produção alográfica de exemplos da mesma classe. O conjunto encontrado é formado por cinco condições, duas no plano sintático e outras três no plano semântico, que passam agora a ser sucintamente descritas:

Exigências sintáticas da notacionalidade:

1. Disjunção sintática: de modo mais preciso, um caractere pode ser descrito como um conjunto de marcas sintaticamente equivalentes. Por exemplo, o primeiro caractere do alfabeto reúne uma variedade indefinidamente numerosa de maneiras de registrá-lo, entre as quais as seguintes: “a”, “A”, “a”, “a”, “A”, “a”, etc., além de modos de enunciá-lo oralmente. A disjunção sintática dá conta de que a classe de marcas de cada caractere contenha todas e apenas as marcas correspondentes a ele, de modo a não existirem marcas que correspondam a mais de um caractere.

2. Diferenciação finita do esquema de caracteres: mesmo que as classes de marcas dos caracteres do sistema sejam disjuntas, pode ser muito difícil na prática definir se uma determinada marca pertence a este ou aquele caractere. A diferenciação finita do conjunto de caracteres do sistema é imposta para garantir que, em face de uma determinada marca, seja possível - ao menos em princípio - decidir inequivocamente a qual caractere essa marca pertence. Essa condição se verifica quando as marcas estão ordenadas de tal maneira pelo sistema que é possível definir um grau mínimo a partir do qual as possíveis diferenças entre elas não mais vão se refletir em diferenças entre caracteres; ou seja, há um nível mínimo para a fineza de diferença abaixo do qual quaisquer diferenças entre as marcas não alteram o caractere a que pertencem.

Exigências semânticas da notacionalidade:

1. Disjunção semântica: as classes dos exemplos de um caractere - denominadas por Goodman de classes de concordância - devem ser disjuntas, de modo que um exemplo dado seja exemplo de um e apenas um caractere. Em relação à música, isso garante que as performances formem classes de tal maneira que 
cada performance figura em apenas uma classe. Desse modo, cada performance é exemplo de uma única partitura. Comenta Goodman: "A exigência da disjunção semântica exclui a maioria das linguagens ordinárias (...) Um sistema notacional não pode conter nenhum par de termos que se superponham semanticamente como "médico" e "inglês"; e se o sistema contém o termo "homem", por exemplo, ele não pode conter o termo mais específico "inglês" ou o termo mais geral "animal". Os caracteres de um sistema notacional são semanticamente segregados", (1976, p. 152).

2. Diferenciação finita do conjunto de classes de concordância: mesmo que cada exemplo de um caractere compareça em apenas uma classe de concordância, na prática pode ser muito difícil definir a qual delas o exemplo efetivamente pertence. A diferenciação finita das classes de concordância é a condição que assegura que - pelo menos em princípio - seja possível determinar, dado um exemplo, a que classe esse exemplo pertence. O que determina se esta definição em princípio será possível é a forma de ordenar as classes de concordância que o sistema de símbolos impõe. Para tanto, elas devem ser ordenadas de forma que exista um grau mínimo de diferença nos exemplos pertencentes a classes diferentes. Grosso modo, a ordem das classes de concordância - posta em vigor pelo sistema - deve impor um limite à semelhança entre exemplos de classes distintas ou, de outro modo ainda, o sistema deve proibir que exemplos de caracteres distintos possam ser tão próximos quanto se queira. "Essa condição, diz Goodman, também restringe apreciavelmente a classe de sistemas que se qualificam como notacionais. Considere, por exemplo, um sistema consistindo de frações em numerais arábicos, totalmente reduzidas, assumindo como elementos concordantes objetos físicos de acordo com seu peso em frações de um quilo. (...) visto que nenhum limite é colocado sobre a diferença de peso que é significativa, sempre haverá muitos caracteres na situação de que nem mesmo a mais fina das medições pode atestar que um objeto não concorda com todos eles", (1976, pp. 152-153).

3. Não-ambigüidade dos caracteres: significa que cada caractere deve fazer referência a uma e apenas uma classe de concordância; o sistema não deve prever caracteres que possam se referir ora a uma classe, ora a outra classe diferente, como sucede, por exemplo, com termos, como "massa”, que possuem 
diferentes campos de aplicação literal, ou como "campo", que admitem aplicações literais e metafóricas.

Das cinco condições a serem obedecidas por um sistema notacional, as línguas naturais violam aquelas relativas ao plano semântico e, portanto, não se qualificam como sistemas notacionais. No entanto, elas obedecem às duas exigências sintáticas: seus caracteres são sintaticamente disjuntos e finitamente diferenciados. Por essa razão, se pode dizer que possuem um esquema notacional de caracteres. Os caracteres de uma língua como o português - desde um caractere simples como "a", até um composto, como uma cópia de um poema épico da literatura portuguesa - tem sua identidade atrelada ao plano sintático, pois, em virtude de atenderem aos dois imperativos sintáticos da notacionalidade, dão origem a uma classe de cópias sintaticamente equivalentes e que podem ser discernidas em relação às inscrições que pertencem a outras classes. Os Lusíadas, por exemplo, pode ser identificado com a classe de todas as cópias sintaticamente equivalentes ao original de 1572. Isto obviamente exclui as traduções para outras línguas, visto que traduções transitam pelo plano semântico, levando em consideração clima, significados e sonoridades de palavras e frases. Pela falta de cumprimento das três condições semânticas ocorre que, em uma seqüência de passos de tradução - indo, por exemplo, do português para o inglês e de volta para o português - pode-se chegar a um caractere que não é sintaticamente equivalente às cópias do poema em português. Isso não ocorre no âmbito da música, que possui um sistema notacional em operação em seu interior. Uma partitura é, majoritariamente, um caractere inscrito em um sistema notacional; se forem separadas as especificações verbais de andamento e expressividade (p. ex. allegro con brio, andante affetuoso, presto aggitato, etc.), que não satisfazem nenhuma das exigências semânticas da notacionalidade, a partitura pode funcionar como instrumento de identificação de uma obra musical. Goodman observa que

(...) a linguagem verbal de andamentos não é notacional. (...) Nenhum afastamento do andamento indicado desqualifica uma performance como um exemplo - mesmo se de péssima qualidade - da obra definida pela partitura. Pois essas especificações de andamento não podem ser consideradas partes integrantes da partitura definidora, sendo antes orientações auxiliares cuja observância ou não afeta a qualidade de uma performance, mas não a identidade da obra. (Goodman, 1976, p. 185) 
É importante, pois, deixar claro que a função principal da partitura é a de ser o instrumento que torna possível a definição unívoca de uma obra de música. O fato de uma performance concordar com uma partitura nada tem a ver com a qualidade artística alcançada por ela, tampouco com a garantia de um alto grau de similaridade entre ela e as outras performances da mesma obra. A única coisa que a concordância com a partitura está autorizada a dizer é que, neste caso, a performance pertence à classe de exemplos de uma determinada obra. Performances da mesma partitura, mesmo a mais específica, de fato podem variar muito entre si. Goodman faz uma síntese destes pontos ao afirmar que: "Uma cópia moderadamente boa [de uma pintura] e a pintura original se assemelham uma a outra em um grau muito maior do que interpretações de uma suíte de Bach por Piatigorsky e Casals", (1976, p. 195-196).

Estes são os elementos básicos da teoria dos sistemas notacionais de Goodman, da qual ele deriva um rico cabedal de conseqüências relativas à identidade das obras e à natureza da simbolização nas diferentes formas de arte. Conforme se poderá observar, eles também formam uma moldura conceitual valiosa para avaliar os problemas envolvidos na construção do modelo em que se tem interesse aqui - um modelo que oriente a inclusão regular de metas estéticas no ensino de física. O passo seguinte será ver de que maneira os conceitos apresentados podem ser mobilizados a fim de propor um modo sistemático de especificar peças de conhecimento científico próprias para apreciação estética. $\mathrm{O}$ alicerce deste desenvolvimento está no conjunto de atributos anteriormente identificados que tornam a obra de arte musical passível de uma definição unívoca e coordenam o processo envolvido em sua apreciação.

\section{Da apreciação musical para a apreciação de peças de conhecimento no ensino de física}

A partir de agora, as idéias básicas da estética, da filosofia da arte e da semiótica de Goodman e outros que foram anteriormente introduzidas serão postas a serviço da articulação de um modelo adequado à interpretação e prática da apreciação estética de exemplares de conhecimento científico no ensino-aprendizagem da física. Seguindo a direção indicada por aqueles princípios, pôde-se constituir a hipótese de que peças de 
conhecimento científico podem ser definidas com razoável precisão a fim de guiar, em linhas gerais, um processo de apreciação análogo ao da apreciação da música. Em complemento à caracterização incipiente realizada até aqui, resta desenvolver com maior rigor esta hipótese, dando-lhe uma configuração específica que constituirá o eixo organizador de todo o modelo.

A construção do modelo de apreciação estética de peças de conhecimento científico se inicia com inferências que podem ser feitas a partir da seguinte constatação a respeito da relação entre as diferentes possibilidades de concretização do mesmo experimento científico:

Nenhum experimento pode ser repetido exatamente. Sempre haverá algo diferente... O que se dá quando se afirma ter-se repetido um experimento é que se repetem todos os atributos de um experimento que uma teoria determina sejam relevantes. Em outras palavras, repete-se um experimento como um exemplo da teoria. (Sir George Thomson in "Some Thoughts on Scientific Method", 1963, citado por Goodman, 1976, p. 177)

Experimentos são, portanto, performances no sentido de que consistem em eventos cuja existência concreta ocupa um lugar e uma faixa de tempo bem demarcados e, sobretudo, porquanto pode haver diferentes projetos do mesmo experimento lançando mão de materiais e arranjos distintos uns dos outros. $\mathrm{O}$ experimento que Galileu executou deixando que bolas descessem por um plano inclinado para verificar a lei do movimento acelerado de objetos impelidos pela gravidade passou, a partir dali, a ser repetido das mais diferentes formas e com os mais diferentes métodos e materiais. O que reúne esses diferentes projetos como exemplos de uma só classe de experimentos são determinados aspectos da teoria ou modelo físico que eles são chamados a ilustrar e exibir. Que ilações podem ser tiradas disto para a definição de peças de conhecimento no ensino de física?

As ocorrências descritas pela física se organizam em domínios fenomenológicos disjuntos. A cada um desses domínios corresponde um conjunto definido de regras que são adequadas à descrição de todas as situações diversificadas por ele abrangidas, e apenas a estas. Por exemplo, no caso das regras que determinam os movimentos que os objetos realizam em resposta a determinadas ações de outros objetos, é necessário ter ciência do fato de que as leis de Newton, com que se descreve o vôo de uma bola em 
direção ao gol em seguida ao chute do jogador, não são adequadas para prever o movimento de elétrons dentro do átomo, nem das partículas nos chuveiros de raios cósmicos, nem tampouco dos jatos de matéria expelidos na explosão de supernovas. Ainda assim, a validade da dinâmica newtoniana se estende aos mais diferentes tipos de situações e objetos, incluindo o rolar da bola de futebol, o movimento de uma peça em uma máquina, o bater de uma janela com a força do vento, a órbita da lua em torno da Terra, a agitação de um grão de pó dentro de um recinto, ou mesmo o deslocamento de um peixe nas águas de um rio. Além disso, conforme seja a sua rapidez, o movimento de um mesmo objeto pode vir a obedecer ora às regras da mecânica de Newton, ora às da relatividade restrita. Desse modo, não se pode identificar a classe de regras de dinâmica que se ajustam à descrição do movimento de um objeto olhando simplesmente para o tipo específico de coisa que ele é, se um animal ou uma rocha, um material esportivo ou um meio de transporte, um planeta ou um grão de areia. Todos esses movimentos variados exemplificam a mesma espécie de dinâmica e, na escolha de um movimento que se deseje dar como amostra da dinâmica dessa espécie, o tipo do objeto que o executa é irrelevante. Como conseqüência dessa independência da dinâmica quanto ao tipo do objeto, acontece de exemplos de uma variedade extrema de tipos se alojarem sob uma classe única de leis de dinâmica. Do mesmo modo que as Variações Goldberg de Bach aceitam como exemplo uma interpretação de João Carlos Martins, mas também outra completamente díspar por Glenn Gould, a dinâmica newtoniana fica definida, não pelo tipo concreto dos itens que são regidos por ela, mas pela concordância desses itens com caracteres em um sistema notacional. Os caracteres notacionais são, neste caso, os enunciados matemáticos das três leis da dinâmica de Newton. Para ver isto, primeiramente, observa-se o atendimento das condições sintáticas para um sistema de símbolos notacionais: os conceitos (força do objeto 1 sobre o objeto 2, o seu par de ação e reação, a duração do impulso, as quantidades de movimento dos diferentes objetos do sistema, produto, derivada, etc.) que são relacionados pelas três leis são sintaticamente disjuntos e finitamente diferenciados, uma vez que as marcas que pertencem a um deles não pertencem a nenhum outro e também podem ser distinguidas umas das outras; de outro lado, as três condições relativas ao plano semântico também são preenchidas: (1) os conceitos envolvidos são semanticamente disjuntos; por exemplo, o atributo dinâmico referido pelo termo "massa" não é o mesmo a que se refere o termo "força" e vice-versa, valendo observações equivalentes em relação a todos os demais símbolos; (2) embora se admita 
que as propriedades a que se referem termos como "massa", "tempo" e "velocidade" possam assumir qualquer valor no conjunto denso dos reais, na prática sua medição está limitada a um nível máximo de acurácia, o que significa que cada um daqueles conceitos determina um subconjunto finitamente diferenciado de símbolos; quanto à diferenciação finita entre dois conceitos distintos como força e massa, basta alegar que as medições dessas propriedades levam em consideração diferentes padrões do sistema internacional de unidades, por exemplo; por último, (3) dentro de um mesmo paradigma científico, a aplicação de um conceito como "massa" está confinada a uma classe única do seu perfil epistemológico e, assim, está livre de ambigüidade.

Resumindo, o que se viu até aqui foi uma indicação de que os corpos conceituais da física alojam sistemas de símbolos notacionais em seu interior. A fim de completar a tarefa de definir peças de conhecimento científico no ensino-aprendizagem da física incumbe agora retomar a comparação feita na seção IV.1. Tal como foi enunciado, o paralelo entre elementos de saber científico e obras de arte musicais e literárias, em termos de suas características enquanto objetos de apreciação, exibe uma feição enganosamente simples. É necessário posicioná-lo diante de uma lente com maior poder de resolução para perceber exatamente os pontos em que ele precisa ser elaborado. Ao fazer isso, a primeira dificuldade com que se topa diz respeito às condições para apreender qualidades estéticas em criações intelectuais. A dúvida pode ser expressa do seguinte modo: não é verdade que a apreciação estética de elementos conceituais é um privilégio reservado apenas àqueles que já adquiriram um grau de proficiência elevado em decifrar e operar com tais elementos? E, se assim for, não estaria desde logo afastada qualquer possibilidade de envolvimento estético nos primeiros estágios da aprendizagem de idéias científicas? Tem sentido um projeto que vise ao desenvolvimento de uma aptidão para apreciação estética do conhecimento científico em indivíduos que não possuem de antemão um razoável domínio das idéias a serem apreciadas?

Aparentemente, as respostas para as perguntas acima são afirmativas. Eis um argumento freqüentemente utilizado para dar respaldo a essas respostas: o aprendiz que começa a palmilhar um roteiro de conhecimento completamente novo para ele tem a perspectiva de um viajante que inicia a travessia de um terreno encoberto por um nevoeiro. Poucos são aqueles a quem a fortuna põe no caminho que conduz ao encontro de relíquias: o destino a eles reservou poderes invulgares de autodomínio diante das 
agruras inerentes ao processo de inserção no campo das idéias científicas, enormes recursos de sacrifício dos interesses imediatos, invejável capacidade de assumir riscos pessoais e um desenvolvimento acima da média da intuição, a ponto de dar a impressão, para quem observa de fora, de que se trata de uma boa dose de irresponsabilidade; estes são os que terão ensejo para fruir esteticamente o que encontrarem ao longo da busca. A opinião costuma fazer sucesso principalmente dentro de nichos que pleiteiam para si a posição de guardiães dos saberes da ciência. Contudo, por mais disseminada que seja, aderir a ela é algo a que se deveria resistir, pelo fato de ser precipitada e por ter como consequiência a negação antecipada da dimensão estética da ciência a mais pessoas que teriam condições de prová-la. É um fato confirmado em qualquer modalidade de cognição que só se pode deter a atenção sobre algo se este algo for correspondente a uma busca, ou então se nesta busca o observador for surpreendido com fatores que contrariam suas expectativas iniciais (Cf. cap. I, seção 3). Deve existir previamente uma crença mais ou menos explícita de que algo bem definido pode ser encontrado, sobre as características disso que pode ser encontrado e sobre a postura que se deve ter diante delas. Tendo em vista o seu caráter cognitivo, na apreciação estética o mesmo princípio segue valendo: não se pode desenvolver um relacionamento apreciativo bem sucedido com um objeto estético caso se ignore a direção em que devem ser buscados os atributos que constituem a base de sua qualidade específica. Até aqui, nada com que não se possa estar de acordo. Entretanto, os felizes integrantes daquela elite fazem vistas grossas para o fato de que, com uma experiência precária do terreno, resumida a umas poucas observações desencontradas e distorcidas recolhidas aqui e acolá, e sem marcos seguros de navegação, são longos demais os períodos em que o aprendiz ver-se-á privado de referências para cruzar o território dos saberes científicos e penetrar os mistérios que nele se ocultam. A aptidão para a apreciação não é uma dádiva celeste, e sem devotar o devido zelo para com o seu desenvolvimento, com o auxílio de alguém com experiência, não há dúvida de que com muita frequiência o aprendiz não assumirá uma atitude de busca. Sendo assim, tornam-se colossais as dificuldades envolvidas em experienciar o percurso como uma exploração para descortinar belezas que estão provisoriamente veladas, se a visão não é esclarecida na mesma proporção do esforço realizado a cada passo dado; tudo o que o viajante nessas circunstâncias procura é voltar a enxergar a claridade familiar do seu local de origem. Suas reações comumente estarão condenadas a duas alternativas: o terror ou o tédio. 
Para sair deste impasse, é preciso notar, em primeiro lugar, que ainda não se problematizou a eventual existência de uma estrutura de níveis no regime da apreciação estética. A pergunta crucial a ser feita é: o contato apreciativo com as criações intelectuais da ciência possui um regime único de funcionamento em todas as circunstâncias? Atentando para a comparação entre objetos de apreciação da ciência e das artes, feita na seção IV.1, nota-se nela uma complexidade que diz respeito a um emaranhamento de níveis heterogêneos. Uma observação mais aprofundada permite discernir a presença de dois níveis de relacionamento apreciativo, associados a dois propósitos distintos que se pode ter em relação a um elemento de saber científico, e correspondentes a dois modos diferentes de desenvolvimento da apreciação. Estes dois níveis podem ser descritos como:

1. Nível de relacionamento com um item do conhecimento científico enquanto instrumento de inserção e participação numa visão de aspectos do mundo que estão além de uma primeira e rápida inspeção;

2. Nível de relacionamento com um item do conhecimento científico como instrumento de atuação sobre o próprio conhecimento científico.

Há, portanto, dois planos no relacionamento apreciativo que pode ser mantido com o conhecimento científico: um, mais íntimo, que é aquele que pode estar em marcha quando um cientista dá forma a uma idéia ou experimento guiado por um senso de adequação, ou então quando é chamado a fazer um julgamento estético no momento da aceitação ou rejeição de um determinado modelo de explicação que desponta no seu campo de pesquisa, em todo caso sob a influência de cânones estéticos vigentes nesse campo (v. McAllister, 1996). Porém, um primeiro nível de contato apreciativo com as noções da ciência tem lugar na posição daquele indivíduo que, conquanto não opere em primeira mão com os instrumentos que se movimentam no processo contínuo de tecelagem e desmanche da fábrica de idéias científicas, é um interlocutor atento a elas por compreender a repercussão que elas têm sobre sua capacidade para romper a grossa camada que está depositada sobre o mundo, revestindo-o com aparência de lugarcomum. Este indivíduo vasculha a ciência à procura de ferramentas intelectuais que possam lhe abrir caminhos ao longo dos quais ele se dê conta de apresentações do mundo cada vez mais ricas, surpreendentes e convincentes. Conforme observa o físico David Bohm, "a ciência é acima de tudo um meio de ampliar nosso contato perceptual 
com o mundo", e seu objetivo consiste em promover "a consciência e a compreensão de um segmento sempre crescente do mundo com que mantemos contato" (citado por Cole, p. 81). Um item de conhecimento científico é um construto teórico e/ou prático de simbolização - conceitos, princípios, hipóteses, teoremas, experimentos, modelos, explicações, etc. - que atua em duas direções opostas: no primeiro plano estrutural, pode ser alvo de processos de mediação por descrição ou exemplificação, sendo estas literais ou metafóricas, veiculadas nas interações dos indivíduos com seu ambiente sócio-cultural; já no segundo nível, parte em direção a outros itens de conhecimento científico, mediante processos simbólicos de descrição ou de exemplificação. Em cada uma dessas direções o processo apreciativo se desenrola de modos distintos.

\section{A aprendizagem do significado da linguagem estética usada em relações com o conhecimento científico}

Alguém poderia imaginar, a princípio, que uma prática docente interessada em promover a capacidade de percepção estética de estudantes acerca de aspectos do conhecimento das ciências se concretizaria com a seguinte decisão simples de um professor: usar freqüentemente com sua turma expressões afirmando a presença de qualidades relacionadas a quão bonitos e agradáveis, ou feios e desaprováveis, são determinados objetos e condutas sob foco nas aulas. Na concepção que alimenta essa intuição, palavras se apresentam como se fossem entidades autocontidas, com vida autônoma em relação a seus usos em situações específicas. Não obstante, nos adverte Wickman (p. 156) de que

devemos reconhecer que a aprendizagem da estética da ciência leva tempo, e não pode ser facilmente resolvida por algumas introduções enfeitadas e atraentes às lições. Os estudantes precisam de ajuda de seu professor e de seus pares para transformar experiências e para aprender a lidar com as inescapáveis experiências estéticas negativas de maneiras que conduzam para experiências recorrentes de consumação, de acordo com o ponto de vista dos estudantes e também com normas da aula de ciências. 
Em pauta nesta advertência, encontra-se, entre outros aspectos, a compreensão wittgensteiniana de que as palavras em si mesmas nada significam. $\mathrm{O}$ seu significado ganha vida apenas com o uso da palavra dentro de uma atividade relacionada a uma prática com propósitos, da qual participamos junto com outras pessoas. A este respeito soma-se Dewey para retratar a experiência estética como algo a ser "encontrado em situações nas quais pessoas se esforçam em direção a um fim que não está dado completamente, mas que não obstante é antecipado" (Wickman, p. 149). "Uma qualidade estética não é algo que seja dado, quer pelo objeto, quer pela pessoa exclusivamente" (p. 142). O valor da experiência estética de um mesmo objeto ou evento é sensível ao contexto, sendo inseparável de uma atividade específica. A ocorrência da aprendizagem de um significado pode ser reconhecida de modo operacional ao observar que os estudantes "se aproximam dos usos habituais de palavras em jogos de linguagem já bem estabelecidos" (p. 126), isto é, observando que aquelas pessoas adquiriram a capacidade de se comunicar em modos que são partilhados por outras pessoas quando engajadas em levar adiante determinadas ocupações inerentes a uma prática. À medida que a aprendizagem se processa, a pessoa vai conquistando uma destreza cada vez maior em dominar o uso de palavras para se comunicar com outras que participam do mesmo empreendimento, entendendo quais são as consequiências que o uso dessas palavras produz em termos de ação, de mudanças de movimentos, de transformação. Em estágios mais avançados, esses usos terão se transformado em hábitos, tal como se fossem padronizados por regras. Esta analogia a regras existente no uso da linguagem estética é suficiente para situá-lo em uma posição para lá das meras idiossincrasias individuais. O que há por detrás disto precisa ser mais bem precisado.

Wittgenstein analisa, em sua obra Investigações Filosóficas, as relações existentes entre expectativas e sua realização. Segundo ele, dar seguimento a uma atividade envolve construir relações entre partes de experiências, pelo uso do discurso e pelas ações dos participantes. Por intermédio dessas relações e da totalidade que constituem no contexto específico em que são tecidas é que as expectativas ganham vida e são dotadas de significado. Isto porque, na passagem de uma situação para outra, um mesmo termo - como o termo belo, por exemplo - sofre variações em seu significado, e o conjunto de todos os significados assim gerados acaba constituindo uma rede de similaridades de família, conforme a comparação feita por Wittgenstein. 
Significados são entidades processuais: aquilo que um termo significa é constituído ao mesmo tempo por continuidades e transformações ao longo da sucessão de situações particulares em que esse termo é usado eficazmente. No longo prazo, as semelhanças entre as conseqüências de cada uso daquela mesma palavra passam a ser como as semelhanças entre as pessoas reunidas como membros de uma mesma família: não resta sequer uma única similaridade que seja compartilhada por todos os diferentes modos de uso da mesma palavra. Sendo assim, não é possível conhecer o significado completo de nossas expectativas senão no momento em que a atividade está completa.

Nem por isso, no entanto, tornam-se vazias de significado as falas em que tais expectativas são formuladas no decorrer da atividade. Quando se faz uso de linguagem estética em relação a uma expectativa quanto a resultados de um processo em que se está implicado, os termos e expressões estéticas exercem aí a função de indicadores: sinalizam para todos os interessados quais cursos de ação são capazes de levar a atividade na direção de um fechamento, e quais não são. Tais falas, portanto, são balizas eficazes da ação mesmo que não se possa dar uma definição explícita dos atributos em que uma consumação para aquela atividade possa consistir universalmente. Considerese, por exemplo, uma situação em que um professor de física, no decorrer de uma aula, propõe que seus alunos façam uma previsão sobre se um simples passo dado por alguém altera ou não o movimento da Terra. Se um dos alunos sugere pensar nisso como a situação de uma mosca pousada em um lustre, imaginando o efeito que ela deve ter sobre esse lustre ao levantar vôo, tem significado imediato o professor dizer: "Esta é uma idéia muito bonita!" Ainda que venham a entender por completo o que faz dela uma idéia bonita somente à medida que construam, de maneira comunicativa e passo a passo, as relações que formem uma argumentação nela baseada, o certo é que boa parte dos estudantes terá sua atenção dirigida para o modelo de pensamento em questão, mantendo uma expectativa positiva de ter seus esforços coroados ao seguir a rota indicada por ele. No momento em que o professor constrói uma relação entre "bonito" e a alegoria do lustre e da mosca, a atividade em que ele se achava envolvido junto com os estudantes atinge um clímax, relacionado a uma expectativa de consumação. A experiência acumulada até o momento da enunciação se torna, simultaneamente por alinhamento e por afastamento, referência para orientar expectativas sobre como se deve agir na situação corrente a fim de fazê-la progredir para uma consumação. Em suma, a 
linguagem estética é instrumento de construção de experiências consumatórias em virtude de suas qualidades de sintetização e de imediaticidade.

O emprego de linguagem estética voltada a dar prosseguimento a uma atividade em um contexto específico tem, desse modo, conseqüências para a aprendizagem de novos significados dos termos e expressões estéticas utilizados. Os significados que os termos da estética possam ter são aprendidos em experiências de funções de exemplificação — no sentido de Goodman — realizadas pelos objetos, eventos e ações que são encontrados ao participar de uma atividade com propósitos. Tomando como base um exemplo de Wittgenstein, Wickman nos lembra de que "Você não aprende com que um bom traje se parece a partir de uma lista escrita de certas características. Você precisa aprendê-lo em encontros com trajes reais e com pessoas falando sobre esses trajes em uso quando envolvidas em diferentes atividades" (p. 66). Essas normas que regulam como se deve agir e falar refletem os propósitos com os quais, mesmo sem ter total clareza disso, as pessoas estão comprometidas até onde estão agindo como participantes de um jogo-de-linguagem específico. Observa-se aí uma importante relação entre exemplificação, experiência e imediaticidade. A exemplificação é possível de ser exercida em atividades que envolvem interações comunicativas e que operam uma síntese de materiais fornecidos por experiências anteriores dos participantes em uma experiência total. A unidade significativa que assim foi forjada, em função de certos propósitos de uma prática delimitados e de outros ainda por delimitar, passa a mostrar, a exibir, a atrair a atenção para alguns de seus traços que ficam patentes como realizações particulares - ou instâncias - de algo que é análogo a um conteúdo cognitivo - i.é, algo análogo a um fato, uma qualidade factual, uma razão. Imediaticidade é o nome que se dá à característica de cada traço colocado em relevo mediante exemplificação de ser passível de ser entendido de pronto, de modo sintético, sumário, sem a atuação intermediária de reflexões ou de análises a seu respeito. A reflexão e a análise são exercidas em um momento posterior, como apreciações em segunda mão de uma situação da qual se acham deslocadas. 


\section{$5 \quad$ Papéis da experiência estética na aprendizagem das ciências: o que dizem as observações}

Guiado pelo conselho de Dewey de que distinções entre categorias não podem ser postuladas como universais, tal como se tivessem sido estabelecidas anteriormente a toda experiência humana, Per-Olof Wickman (2006) realizou um estudo empírico a respeito das funções das experiências estéticas tal como são observadas nos discursos e ações encenados no contexto de ensino e aprendizagem das ciências. Basicamente, o que estas observações apontam é que aprender a fazer uso correto da linguagem estética em atividades diretamente voltadas ao conhecimento científico tem relevância para os propósitos característicos dessas atividades. De fato, isto é algo que se deveria esperar. Para compreender o porquê, basta atentar para o fato de que experiências estéticas envolvem "aprender um modo de ver e de fazer, de construir tipos específicos de distinções acerca do que pertence e não pertence a uma atividade determinada" (Wittgenstein, 1967, p. 202, comentário de Wickman, p. 67). Ora, a atividade científica diz respeito ao domínio de modos de ver e de discernir em seus mais variados momentos. São distinções quanto a: i. aspectos detalhados e visões globais do mundo que a ela pertencem ou não; ii. similaridades e distinções entre conjuntos de fenômenos; iii. que explicações são ou não aceitáveis; iv. quais problemas interessam e quais não; v. que conjunto de variáveis, quais materiais e que métodos de solução usar ou não, entre outras. No fluir da experiência histórica da humanidade, bem como no curso da experiência construída por um indivíduo particular em sua vida, linhas de corrente correspondentes ao fluxo de termos cognitivos, normativos e estéticos não se mantêm paralelas, mas se cruzam e emaranham em padrões complexos. Assim, quando a experiência estética tem lugar como parte de uma atividade específica, tal como o processo de construção de conhecimento científico na pesquisa, ou de sua reconstrução em um curso de ciências, o conteúdo do discernimento que ela põe em ação não pode ser separado em categorias isoladas de fatos, valores e normas. O emprego de termos estéticos situado em uma prática científica não faz referência apenas e exclusivamente a qualidades do mundo ou a estados emocionais do sujeito, mas sim exerce funções que, conforme as necessidades da prática, integram avaliação, descrição e fundamentação ao mesmo tempo. Sendo a prática estreitamente comprometida com propósitos científicos, a experiência estética nela situada deverá pôr em relevo as distinções que são relevantes 
a partir de uma perspectiva da ciência - embora possam ser, e não raro são, relevantes também para pontos de referência situados em outras práticas. O estudo de Wickman isolou quatro diferentes papéis que experiências estéticas assumem neste cenário:

\section{0 papel: de continuidade e de transformação dos aspectos normativos da experiência}

A este respeito, apareceram envolvidas em aprendizagens de distinções entre quais eram os modos certos e errados de proceder, que objetos e eventos eram relevantes e irrelevantes, e em relação a traços que se esperava que fossem discernidos na aula de ciências. "Professores e estudantes usavam juízos estéticos positivos em relação a ações e coisas que de acordo com eles deveriam ser incluídos e que traziam a antecipação de poder conduzir as ações dos estudantes em direções desejadas. Juízos estéticos estavam, desse modo, associados com momentos de expectativa e com movimentos para consumação e para um fechamento das atividades da aula" (p. 135). Algo desse tipo é observado como parte de um episódio que Per-Olof Wickman relata (p. 87): duas estudantes em uma aula de laboratório de zoologia têm de descrever a morfologia de insetos; como os espécimes à disposição diferissem quanto ao estado de conservação de suas estruturas corporais, havia o problema de discernir o que era uma característica inerente a insetos como classe e o que não passava de um traço acidental, produzido pela falta de um elemento presente em insetos com a integridade preservada. Por meio de relações estéticas e de trocas comunicativas estabelecidas entre elas e outros estudantes durante a aula, as duas construíram distinções entre insetos que eram adequados e aqueles inadequados para o seu estudo. Juízos estéticos eram enunciados com o efeito de construir relações normativas e chamar atenção para essas normas e para a expectativa de consumação que a elas se ligava; como nesta relação que efetivaram entre i. "ser um inseto com boa estrutura e bem arranjado"; ii) "ser possível de usar"; e iii) expressões estéticas que implicavam em o inseto "ter uma configuração geral clara e ordenada". Essas distinções eram compartilhadas pelas estudantes e, além de estéticas, eram ao mesmo tempo normativas por incluir a expectativa de que a distinção feita ali pudesse ser generalizada como uma regra a respeito do tipo de inseto que deveria ser selecionado para consumar propósitos da disciplina de zoologia.

As experiências estéticas negativas, por outro lado, diziam respeito à percepção de modos de agir, ocorrências e objetos que, em vista do interesse em impelir a atividade em direção a uma consumação, deveriam ser excluídos ou evitados. Ao longo 
da ocorrência de experiências estéticas negativas e positivas, em momentos de expectativas ou de fechamento, elas tinham como resultado conectar e integrar as diferentes atividades dos estudantes, além de conectar também as diferentes relações que tinham tido sucesso em construir (Wickman, p. 136). Também foram observadas por Wickman experiências estéticas com continuidade normativa que eram, não apenas negativas, mas de um tipo discordante das exigências colocadas pela aula. Diferentemente das experiências estéticas positivas e das negativas, as experiências negativas discordantes expunham um conflito: de um lado, estão exigências normativas da aula de ciências relativas a modos de proceder e, de outro, as disposições dos estudantes para evitar e excluir esses procedimentos de seus afazeres. Quando há um insucesso em transformar o conflito em um juízo positivo, ou quando não se encontra um modo alternativo de ação que permite evitar aquilo que desencadeia a contradição, os estudantes são constrangidos a agir contra seu juízo. Em razão da continuidade normativa desse modo de funcionamento das experiências estéticas em atividades de ensino-aprendizagem em uma disciplina científica, elas podem produzir consequiências sobre a visão construída pelos estudantes a respeito do lugar que ocupam em relação à ciência: conforme experiências estéticas positivas vão se tornando recorrentes em encontros de uma pessoa com objetos, eventos e ações relacionados com a ciência, isto sinaliza para ela a expectativa de que condutas e modos de pensar influenciados pelo conhecimento científico podem se integrar à sua identidade; se, pelo contrário, experiências negativas de discordância se repetem de maneira sistemática, o estudante com mais chance perceberá as atividades de educação em ciências como algo que põe sua identidade em risco, resultando provavelmente na sua exclusão dessas atividades, ou até mesmo em sua separação da ciência em bloco. Visto que um aspecto da aprendizagem de ciências é a transformação de modos de agir e, portanto, também de normas, se não houver transformação da relação de conflito entre o que o estudante deseja e as necessidades da aula em relações de consentimento estético pleno, ele não terá condições de criar boas expectativas quanto à sua participação futura nos trabalhos da aula (Wickman, p. 120-121).

\section{$2^{o}$ papel: de continuidade e de transformação dos aspectos cognitivos da experiência.}

Em determinadas ocasiões o que fica à mostra no primeiro plano das experiências estéticas positivas e negativas não são indicações de como se deve ou não agir, o que se 
deve incluir na atividade ou dela excluir. Aqui, o uso de linguagem com conotações estéticas se manifesta na construção de relações de expressões ou termos estéticos com fatos da ciência. Wickman observa um exemplo dessa espécie de continuidade cognitiva da experiência estética em uma ocasião ocorrida no contexto de uma aula de laboratório de uma disciplina universitária de química. Um grupo de estudantes busca determinar o conteúdo de uma amostra, quando o professor nota a mudança de coloração no tubo de ensaio que eles estavam examinando. Palavras do professor: "Uau, que bela cor. Mudou [a cor] aqui. Sim, é cobalto" (Wickman, p. 110). Nesta fala dirigida aos estudantes naquela atividade específica de análise de amostras, o significado que o adjetivo "belo" adquire é diretamente condicionado pela relação estabelecida entre o termo estético, a qualidade factual relevante (cor da amostra), e o acontecimento de mudança de cor. Ele é usado como indicador de uma relação cognitiva. Explica-se: a conseqüência que se segue ao uso de "belo" é a construção de uma relação que identifica um fato - a presença do cobalto na amostra. $\mathrm{O}$ uso aqui feito do predicado estético é, portanto, voltado a dirigir a atenção para essa relação cognitiva, construída para dar seqüência à atividade. Conteúdos cognitivo, normativo e estético se combinam sob este emprego da palavra "belo".

Por outro lado, usar um termo estético negativo para se referir ao cheiro de uma amostra como sendo peculiar a uma substância determinada implica em fazer a distinção de que esse cheiro é um elemento que deve ser incluído na atividade de caracterização. Aqui, discernir esteticamente tem como conseqüência discernir uma qualidade factual - neste caso, o cheiro; e, em uma aula de ciências, discernir a relação da qualidade factual com um objeto específico - i.e, um fato científico - significa discernir um procedimento relevante, pertinente aos propósitos da aula. Em outras palavras, para identificar corretamente a amostra deve-se incluir o cheiro: ele é um argumento que justifica a identificação da substância. Observa-se aí a continuidade entre normas e fatos, de um lado, e a experiência estética, de outro.

Sob outro de seus modos de uso, relações entre fatos e termos de estética foram observadas para denotar qualidades puramente factuais de que se necessitava para descrever coisas. Para entender esse modo de funcionamento da linguagem estética, considere-se um caso em que um odor relacionado ao termo estético "horrível" é apresentado em uma aula de química como argumento para o fato da presença de uma substância em um tubo de ensaio: o predicado "horrível" possui para os participantes da 
aula uma função descritiva, e não simplesmente avaliativa, do cheiro que identifica a substância. Com o respaldo de relações feitas em outras experiências desse mesmo cheiro, a experiência estética do odor faz discernir o fato concernente à substância contida na amostra.

Em adição, aquelas relações exerciam uma função de apresentar razões que davam fundamento a uma ação específica, ou de apontar a distinção entre fatos cientificamente relevantes e irrelevantes. Características factuais e normativas da situação eram integradas em uma única expressão. Dois exemplos são de grande interesse aqui. No primeiro, desejando que os estudantes dirigissem sua atenção para reagentes que deveriam usar em sua atividade de determinação de amostras, o professor de química lhes disse: "Vocês têm muitos cloretos que são legais [fun] aqui (p. 107)". Em outra oportunidade, um professor de ecologia fez distinções acerca de animais que teriam enorme proveito para estudos futuros se fossem apanhados pelos estudantes, dizendo que eles eram "legais [fun] de olhar ao microscópio" (p. 108). Observa Wickman (p. 108) que

Quando os professores diziam a seus estudantes que coisas seriam legais de observar, eles ao mesmo tempo argumentavam como se esses juízos estéticos dissessem respeito a qualidades factuais associadas a certas maneiras de proceder na aula de ciências. Relações estéticas foram os únicos argumentos oferecidos pelos professores. Em todos os casos mencionados, razões eram dadas em termos de uma antecipação de experiências estéticas positivas.

Além disso, vê-se que o caráter discordante em experiências estéticas negativas pode ter uma origem cognitiva, na medida em que a falta de condições para a construção de relações relevantes envolvendo fatos e conceitos científicos conduza a expectativas negativas quanto a maneiras de proceder necessárias à aula de ciências.

\section{3ำ papel: elaborar e ordenar situações diversas, transformando-as ao mesmo tempo em que são tornadas contínuas com a vida}

O viés de participação da construção de pontes entre o universo de experiências prévias não científicas dos estudantes e as experiências científicas a serem construídas nas aulas é um dos aspectos do conceito de continuidade. Nesse sentido, continuidade tem a ver com "conexões que pessoas fazem entre diferentes situações e encontros. Continuidade, aqui, designa aquilo que as pessoas podem usar de experiências anteriores para levar 
adiante novas experiências "(Wickman, p. 110). Essa implicação da continuidade da experiência é patenteada em três características observadas no uso de juízos estéticos nas aulas de ciências. Primeiramente, nota-se que os termos estéticos usados pelos estudantes em situações de aprendizagem não são termos especializados, mas provém de atividades do próprio cotidiano das pessoas.

Em segundo lugar, a menção explícita que os estudantes costumam fazer de algumas de suas experiências estéticas anteriores com a finalidade de estabelecer relações que permitam discernir fatos científicos. Como exemplo, pode-se mencionar um dos episódios de aula de ciências na universidade analisados por Wickman (p. 104), no qual uma estudante relacionou evidências que a levaram a determinar que uma de suas amostras continha ácido clorídrico. Uma dessas informações cruciais foi o odor que a amostra exalava. Sua atenção foi dirigida para ele em virtude das experiências que havia tido com o cheiro marcante do cloro em piscinas públicas, referido por ela por expressões avaliativas como "incrivelmente ruim" e "um dos mais repugnantes que existem". Vale dizer também sobre este exemplo que o predicado aplicado à qualidade da sensação olfativa é não apenas avaliativo, mas ao mesmo tempo um predicado descritivo de uma qualidade factual. A qualidade desagradável do cheiro é objeto de uma sensação que serve à cognição. O que a estudante fez foi re-conhecer um acento, uma marca distinta própria de um objeto, capaz de indicar de que tipo ele é. O caráter negativo particular notado por ela no odor da amostra foi o ponto de partida para a construção de uma relação oferecida como fundamento para a presença do $\mathrm{HCl}$. Em outras palavras, como conseqüência da construção dessa relação, por referência a experiências avaliativas no passado, foi erigida uma razão para um fato. Em suma, a continuidade com experiências anteriores, ao lado de outra continuidade, entre estética e cognição, permitiram, neste caso, o avanço da atividade para um fechamento.

Por fim, as experiências estéticas encontradas nas aulas de ciência têm continuidade com traços gerais da vida dos seres humanos. Isto é visível no encaixe das experiências estéticas dos estudantes em padrões de ação recorrentes que estão presentes não só nos processos da educação científica, mas na ação humana em geral. Usos da linguagem estética se estabelecem à maneira de modos regrados, ao comparecer com elevada freqüência em momentos de antecipação - apontando para uma consumação por vir; e em momentos de fechamento consumatório - mostrando o culminar de um processo com uma fusão realizadora de múltiplos elementos de 
experiência. Em virtude de favorecer a construção de ligações vigorosas dos significados inerentes às aulas de ciências com os significados vitais dos estudantes, as experiências estéticas têm um potencial elevado para promover a aprendizagem de fatos, conceitos e procedimentos científicos.

\section{4º papel: compartilhar e comunicar experiências que fazem avançar as atividades das aulas de ciências}

A eficácia comunicativa da linguagem estética se deve à sua imediaticidade. Em determinadas situações, o uso de um único termo ou expressão de propósito estético tem a capacidade de ocasionar que ingredientes de diversas experiências anteriores sejam fundidos e ressignificados em uma única experiência total. Esta experiência então adquire a feição de uma identidade com existência autônoma, tal como se fosse uma unidade objetiva. Os participantes da atividade em que uma integração imediata se realiza pelo uso de expressões estéticas têm a percepção de um aparecimento análogo ao de um fenômeno objetivo. Este caráter de objetividade de que se reveste a experiência é reforçado pela adesão dos modos de uso da linguagem estética na atividade em questão a padrões recorrentes, encontrados tanto em uma situação específica de aprendizagem científica quanto em outros contextos de uso. São padrões que se referem à presença freqüente desse tipo de linguagem em momentos de antecipação de uma consumação, ou da consumação propriamente dita. Nem sempre tais expectativas e consumações a que se relacionam os termos estéticos usados estão situadas nas atividades correntes em que os estudantes estão engajados. Muitas vezes, elas se encontram nas experiências dos estudantes em outras ocasiões:

A expectativa de ficar enjoada ao nadar foi relacionada a um cheiro encontrado na aula de química, e as expectativas gustativas associadas a um doce foram relacionadas à aparência de uma estrela-do-mar. Desse modo as experiências estéticas de outras atividades e jogos de linguagem eram tornadas contínuas com as experiências do trabalho em aula (Wickman, p. 107).

Em ocasiões nas quais experiências de fusão adquirem os mais altos graus de imediaticidade, os juízos estéticos que catalisam a integração assumem o peso de declarações definitivas, dando a palavra final a respeito de algo o que é o caso. Isto significa que, nestas circunstâncias, juízos estéticos são usados na comunicação entre pessoas engajadas em uma atividade de ciências, e entendidos por todos os usuários 
competentes como afirmando a correção definitiva de um modo de agir, ou embasando a verdade necessária de um fato, em relação aos propósitos da prática de que estão participando. Vale à pena citar o trecho de Art as Experience em que Dewey delineia sua concepção holística de experiência estética:

Contudo todos os elementos de nosso ser que estão exibidos com ênfases especiais e realizações parciais em outras experiências são fundidos na experiência estética. E eles são tão completamente mergulhados [merged] na totalidade imediata da experiência que cada um deles é submergido: - ele não se apresenta à consciência como um elemento distinto.

Sobre esta passagem, Wickman observa que caso seja "interpretada em termos comunicativos, um juízo estético, quando enunciado em uma situação apropriada de antecipação ou consumação, tem a capacidade, por si próprio, de sumarizar inúmeras relações, sejam elas de conteúdo estético ou cognitivo ou de qualquer tipo de conteúdo que produza movimento de avanço" (p. 137).

\section{As peças de conhecimento científico e suas performances no ensino de física}

Assim, para dar conta da questão sobre que condições tem um estudante, em sua pouca experiência, de apreender qualidades estéticas nas criações intelectuais da física, qualquer resposta deverá partir da constatação da existência dos dois níveis identificados na apreciação de elementos de saber da ciência e, ao mesmo tempo, se basear nas consequiências que podem ser abstraídas dos modos concretos de uso da linguagem estética observados por Wickman. Em face desses vínculos, levar adiante a analogia com o campo da música demonstra ser uma abordagem eficaz.

A tarefa do intérprete na música é de fazer a metáfora sonora da obra que o compositor concebeu em seu pensamento abstrato com símbolos musicais, visando ao mesmo tempo, pela invenção de uma riqueza de meios engenhosos, criar uma concepção do que a obra é e transmitir essa visão da forma mais clara possível ao receptor. $\mathrm{O}$ intérprete procura agir pela criação de visões ou amostras sonoras por intermédio das quais o receptor possa vir a criar familiaridade com a obra abstrata. 
Estabelece-se, assim, em primeiro lugar, um paralelo do compositor de peças musicais com um corpo de cientistas que, coetaneamente ou em momentos históricos diferentes, realizam esforços conjugados a culminar no surgimento de uma peça de conhecimento da física. Em segundo lugar, o papel do intérprete de peças musicais é análogo ao do professor de física: cabe a este último, ou outro intermediário com o propósito de abrir caminhos de interligação do pensamento do estudante com o mundo das idéias abstratas da física, conceber mecanismos de transformação adaptados para promover a construção pelo próprio estudante de pontes para os significados presentes naquele mundo.

Uma peça de conhecimento físico, da maneira como passamos a defini-la a partir de agora, consiste na classe de exemplos de um artefato simbólico ordenador do mundo físico, instituído por uma configuração determinada de regras da física para as quais é possível escrever um caractere notacional. Um exemplo, já mencionado, de peça de conhecimento da física é o sistema formado pelas três leis da dinâmica newtoniana. Por outro lado, em razão de que a peça possui comumente uma grande extensão e um grau elevado de complexidade, uma apresentação completa de suas qualidades não pode ser realizada por intermédio de uma única performance. É de grande valor observar o que tem a dizer Osborne a esse respeito:

No caso das artes de performance uma realização dupla se constrói na apreciação. Uma performance implica interpretação e, por assim dizer, uma realização prática da obra registrada por parte dos executantes (ou do produtor). A performance em si deve ser realizada em atenção e em percepção pela platéia. A platéia alcança uma concepção da obra de arte por extrapolação de várias performances, reais ou imaginadas, não havendo duas (exceto no caso dos filmes) exatamente idênticas. Não é possível ver exatamente a mesma performance duas vezes - embora no caso da música esta restrição tenha sido até certo ponto superada pela gravação em disco da performance. Como cada performance necessariamente acentua alguns aspectos da obra de arte às expensas de outros, o observador pode apreender em apreciação apenas os aspectos que são trazidos à proeminência em cada performance. A situação contrasta com a que se aplica à literatura, à pintura, à escultura e à arquitetura, nas quais o observador pode repetidamente recorrer a um substrato material 
imutável e anunciar ele mesmo as mudanças em seu modo de realização. (Osborne, 1978, p 187)

Ao falar de uma "performance de uma peça de conhecimento da física", a idéia central a ser focalizada é a de que, por intermédio de uma determinada seleção e ordenamento de meios e experiências por um professor ou outro intérprete, seja gerado um símbolo que aponte para aspectos notáveis de um determinado perímetro do continente abstrato desta ciência. É importante esclarecer que o modo como aqui se está interpretando a teoria dos sistemas notacionais de Goodman em favor da análise de peças de conhecimento científico não é um gesto arbitrário e de distorção. Como se atesta pelo excerto a seguir, o próprio autor prevê, em sua exposição dos conceitos aqui utilizados, uma amplitude de aplicação que excede a análise da simbolização na arte da música:

Um registro é um caractere em um sistema notacional. (...) Ampliei a aplicação de "registro" [score] para abraçar caracteres do tipo descrito em qualquer sistema notacional, não meramente na notação musical. Similarmente, com frequiência eu chamo de performances os elementos concordantes com esses caracteres, em que esses concordantes não são execuções no sentido ordinário do termo, nem mesmo algum tipo de evento; e freqüentemente chamo as classes de concordância de obras, mesmo quando essas classes são tais - por exemplo, agregados fortuitos de objetos naturais - que não sejam obras em nenhum sentido usual. (Goodman, pp. 177-8)

A fim de concorrer para a finalidade da apreciação estética do continente da física, a performance está obrigada a fazer referência ao conteúdo primário da peça - o modo específico de organização do mundo físico que ela efetiva - uma vez que a apreciação estética não se estabelece no vazio; esta porém é somente a primeira função simbólica da performance, e por vezes é insuficiente para sustentar uma expansão continuada da visão estética. Outra função fundamental do símbolo concretizado em uma performance é chamar atenção para traços constitutivos do conhecimento produzido no âmbito da física que podem se tornar manifestos na peça em questão. A percepção do valor estético da performance está diretamente relacionada com a capacidade de notar de que forma os meios que ela mobiliza lhe asseguram uma elevada aptidão para exprimir significados vinculados à peça exemplificada. O valor estético 
pode ser apreendido focalizando a atenção para qualidades da peça e da performance como:

- A maneira como a peça ou performance tematiza o encaixe harmonioso existente na concatenação de uma certa coleção de conceitos e princípios heterogêneos;

- A maneira como a performance é capaz de trazer à tona uma compreensão profunda da natureza por intermédio de meios simples e econômicos;

- O modo como a performance revela a aparição do grandioso em meio ao efêmero, o entrelaçamento das coisas mais insignificantes com uma organização de grande escala;

- O modo como uma peça ou performance viabiliza meios para pôr em evidência nuances delicadas do mundo que até então se encontravam soterradas por uma camada de outras manifestações com capacidade de interferência e visibilidade muitíssimo maiores;

- ou cria uma percepção dramática, aguda do poder inexorável e majestoso das leis naturais, envolvendo seus apreciadores em uma atmosfera de assombro;

- ou coloca em foco uma sutil mudança de ponto de vista que realiza um completo rearranjo de uma compreensão arraigada dos comportamentos da natureza;

- ou, ainda, o modo como a peça encarna uma lição a respeito de um significado de caráter geral do empreendimento da física - de algo que lhe confere uma especificidade marcante em meio a outras visões de mundo desenvolvidas pelo ser humano - ao fotografar um dado modo especial em que esta ciência funciona e o que isso representa para a relação do ser humano com o mundo.

Longe de ter a pretensão de fornecer uma lista exaustiva, os tipos de qualidades estéticas apontados aqui cobrem apenas uma estreita faixa das fontes de valor que podem ser encontradas mediante o contato apreciativo com performances adequadas de determinadas peças de conhecimento físico. Em todas elas, é possível observar a assinatura da forma especial com que a beleza se apresenta nos saberes da física: a abertura para uma dimensão mais profunda e abrangente da existência, um rasgo através do qual se alcança a visão de facetas que a um só tempo surpreendem e evocam um senso de adequação, conduzindo à reestruturação da percepção do mundo físico e 
convidando a realizar alguns dos mais nobres potenciais do humano: a experiência de participação nos segredos do universo e a fruição de um sentimento de intensificação da própria vida.

\section{$7 \quad$ A arte da performance no ensino de ciências}

Em face de uma riqueza de roteiros alternativos, o poder garantido pela aliança entre ciência e técnica decretou que a produção de significado para o conhecimento científico seguisse uma direção única. Para começar a ir em direção à finalidade da apreciação estética dos artefatos simbólicos e processos científicos é preciso, antecipadamente, desenrijecer consolidações que se estabeleceram na interpretação cultural da ciência. Em inúmeras situações de aula de ciências, professor e estudantes se vêem às voltas com a tarefa de decidir se determinados pontos, explicações ou questões levantados no momento fazem ou não sentido. Em algumas dessas ocasiões, ganhar-se-ia tempo e muitos problemas de entendimento mútuo seriam evitados se, antes de assumir a tarefa, os envolvidos parassem para discutir as bases do que cada um está pretendendo ao falar em significado. Ao adentrar em um círculo novo ou ao reexaminar um antigo, é necessário desenvolver uma noção sobre o que significa "significar" e "ter significado" nas atividades que se realizam naquele meio.

Do ponto de vista analítico, dizer que um enunciado faz sentido pressupõe um procedimento que ninguém tem condições de realizar de fato: provar que o conhecimento que se tem das propriedades de um item de mundo é autônomo em relação a tudo o que se afirma sobre elas. Nenhum significado pode estar sustentado exclusivamente por um objeto do mundo exterior; todo significado é ao menos parcialmente constituído de experiência humana. Conforme o que já foi suficientemente debatido aqui, não se pode ter acesso ao significado absoluto de uma coisa. Em vez disso, significados são avaliados do ponto de vista de um conjunto implícito ou explícito de fins a que se decide ou se assente ou se é forçado a aderir. Aprender um significado diz respeito a vir a partilhar das formas como a linguagem é habitualmente usada no contexto de uma prática, de modo a levar ao reconhecimento daqueles aspectos que ajudam a cumprir os propósitos dela. O que quer que venha a adquirir significado o faz em virtude de ir ao encontro de um propósito ou interesse 
compartilhado por pessoas envolvidas em um esforço comum. Assim, as ações mobilizadas ao participar de uma atividade terminam tendo seu significado influenciado pelas conseqüências para as quais elas concorrem.

Aquilo que uma coisa é ou significa é dependente, entre outros fatores, da maneira em que ela está sendo usada, da função que ela é designada a executar e dos propósitos aos quais ela está sendo levada a atender. Portanto, alterar a função de algo implica em transformá-lo e, ao menos dentro de certos limites de tempo e espaço, em modificar o que ele é. Ao mesmo tempo, transformar o seu modo de uso e/ou de operação depende de e colabora para transformações no modo como os indivíduos que interagem com o objeto o compreendem. São transformações no modo como são reconhecidas similaridades e distinções, afinidades e afastamentos entre esse e outros objetos. Ao longo desse processo, as reconfigurações na compreensão do objeto significam a abertura da possibilidade de interagir com ele em novos contextos e de novas maneiras. Mudando as formas de compreender, as ações dos indivíduos também mudam.

Se aplicada ao conhecimento científico, esta linha de raciocínio traz duas conseqüências importantes. Primeiro, leva a procurar nos modos costumeiros de se relacionar com a ciência sinais que apontem para as finalidades a que eles conduzem. Segundo, permite julgar o cabimento dessas finalidades e a perceber outras formas de valor que podem estar sendo preteridas ou sufocadas. Ao seguir no encalço das aparições públicas da ciência o que se revela, então, é que a compreensão da totalidade do seu território está sob a dominação férrea de propósitos que representam somente uma de suas províncias: os valores associados à técnica, como predição, manipulação, eficiência, produtividade e reprodutibilidade. Porém, a ciência comporta outros valores que também merecem ter visibilidade ao lado daqueles. Para uma perspectiva puramente técnica, o que conta é a adaptação dos indivíduos a situações em que o controle e a manipulação se afirmam como absolutos. O próprio indivíduo, submetido a esta adaptação, desce à condição de objeto. Os valores estéticos da ciência fazem o devido contraponto a este estado de coisas. A fim de restituir o equilíbrio nos propósitos com que a ciência se mostra publicamente comprometida, há a necessidade de fazer um movimento desde a adaptação ao dado da verdade instrumental para a participação de experiências dos artefatos científicos. 
Estas experiências, para serem estéticas, devem ter como horizonte dar aos participantes meios para observar o modo como um senso de adequação está sendo exemplificado por uma peça de conhecimento científico. No entanto, não é possível dar conta deste objetivo partindo da premissa de que as virtudes estéticas da ciência somente se revelam aos que, ao fim de um longo e árduo percurso, se alçaram a um cume de onde ela pode ser apreendida racionalmente em sua estrutura geral, abstrata e final. Em lugar desta concepção, outra mais bem ajustada se erige afirmando ser viável que os indivíduos aprendam a discernir qualidades estéticas na experiência integral das apresentações singulares, concretas e variáveis do conhecimento científico. Na realização de uma aprendizagem, não se passa diretamente da exposição a um artefato para a compreensão das suas conseqüências gerais para uma prática, sem o concurso de eventos singulares de mediação. Entre experiência concreta e artefato abstrato, uma passarela de relações deve ser construída. Por definição, a mediação entre uma experiência concreta dos saberes da ciência e suas construções simbólicas generalizadas é uma performance singular.

Por detrás de toda performance existe sempre uma peça abstrata de conhecimento que ela concretiza. O critério de se encaixar como exemplo de uma mesma peça específica define um conjunto de realizações singulares do mesmo tipo. Contudo, nem todas as performances da mesma classe são boas concretizações da peça. O ideal de uma boa performance é a busca de um modo eficaz de construção de roteiros que conduzam à percepção e ao compartilhamento de significados das adequações que uma peça de conhecimento científico carrega. Sendo assim, estas concretizações devem se concentrar em dar ênfase à percepção das relações em que foram ordenados determinados elementos de experiência e de funcionamento simbólico em função de exemplificar atributos gerais da peça. $\mathrm{Na}$ experiência de uma performance, estas relações constituem os objetos elementares da percepção.

\section{$8 \quad$ Performances como amostras}

De uma forma despojada de tecnicalidades, poder-se-ia caracterizar uma peça de conhecimento físico como uma estrutura intelectual, abstrata (invariante por mudanças no contexto e nos exemplos particulares aos quais se aplica), com significados 
potenciais em múltiplos níveis, formada de relações entre axiomas, conceitos, princípios e regras operacionais de um modelo (ou de uma simulação mental, ou de um projeto experimental). Do mesmo modo que obras musicais permanecem em uma condição de abstração até o momento em que são concretizadas por intermédio de execuções por um conjunto de músicos, também no ensino de física as peças de conhecimento físico precisam ser inseridas em um espaço e um tempo particulares a fim de que os estudantes possam construir um relacionamento com os seus padrões abstratos, conectando esses padrões com compreensões específicas do mundo físico. Esta função é reservada às performances das peças de conhecimento físico, que consistem em eventos de mediação planejados para a concretização de amostras que projetem para certos aspectos selecionados da configuração sistemática da peça. Uma performance, portanto, se realiza em uma situação singular e abrange objetos, ações e participantes particulares. Performances devem então fazer uso de mecanismos adaptados para inserir as relações abstratas de uma peça em eventos concretos de mediação, levando em consideração os elementos contextuais que serão encontrados na situação educativa.

Uma vez tendo sido introduzidos estes conceitos, a atenção se volta para a constatação de que o organismo do conhecimento físico escolar tem estrutura análoga à do domínio da música culta ocidental. Depois de terem sido apontados critérios para reconhecer ocasiões em que se está diante de uma peça de conhecimento físico com virtudes estéticas, é momento de dar novo passo e erigir uma compreensão sobre o significado de uma performance ser um evento de mediação esteticamente bem planejado. A questão que ora se levanta é a de como incorporar elementos estéticos no planejamento da mediação do conhecimento físico. Abre-se, assim, a perspectiva de uma estética do planejamento de performances de uma peça de conhecimento.

De acordo com a versão que se construiu para interpretar a apreciação estética na educação em ciências físicas, uma peça de conhecimento físico possui virtudes estéticas quando seus modos de funcionamento simbólico - as distinções, similaridades e ênfases que ela libera - lhe conferem uma configuração inteligente que ela empresta para a compreensão de um setor do mundo físico. Esta configuração inteligente reside na interconectividade dos conceitos e normas da peça, e destes com os setores do mundo físico que a peça permite compreender. Logo, no que respeita às virtudes estéticas das performances, o critério principal que permitirá discernir entre performances esteticamente corretas e incorretas é o elemento da compreensão. 
Conforme se buscou realçar no segundo capítulo, a esse elemento de compreensão correspondem experiências com as características de alternatividade, comunicabilidade e totalidade. Assim, qualquer mediador que decida enfatizar o objetivo de dar lugar para que estudantes estabeleçam um relacionamento estético com o conhecimento da física deve se defrontar com uma indagação relativa ao grau em que o resultado do seu planejamento de performances favorece a formação da compreensão sobre a peça. Por sua vez, essa questão irá remetê-lo imediatamente a outra: como resultado do planejamento realizado, existe interconectividade de peça e performance ou, em outra terminologia, forma-se uma totalidade de PP?

A formação de uma totalidade de PP é a principal fonte das virtudes estéticas que podem ser encontradas nas estruturas planejadas de mediação do conhecimento físico. Não se trata, aqui, de fornecer uma receita para a construção de performances esteticamente boas. $\mathrm{O}$ que se pretende é apresentar uma maneira de conceber a mediação que condicione a busca e que permita avaliar o seu resultado.

Mais do que uma instância pertencente ao campo de aplicação das relações entre conceitos e normas que constituem a peça, uma performance deve ser planejada como uma amostra que exemplifique determinados aspectos dos padrões formados por aquelas relações. Neste contexto de formação de uma estrutura de peça-performance, a função simbólica de exemplificação é executada pela performance mediante o procedimento de selecionar uma faceta particular da peça para colocar em foco, a fim de exibi-la sob esse aspecto específico, que emerge valorizado em meio a outros possíveis. Para a finalidade de entender este significado da função de exemplificação, é útil considerar o exemplo de uma unidade didática planejada para formar a compreensão de idéias básicas de estrutura dos materiais. Dentro desta unidade figuram inúmeras peças relacionadas entre si: uma delas é o conceito abstrato e multifacetado de ligação química. A preparação da exemplificação a ser executada por uma performance deste conceito deve tratar de selecionar algumas das relações nele implicadas para serem exibidas e dispostas em um padrão estrutural. O mediador pode ter em mente, por exemplo, planejar uma performance composta de dois momentos. No primeiro, a discussão de uma maneira de estimar o número de átomos presentes em uma tira de borracha é preparada para funcionar como modo de chamar atenção para as distâncias de equilíbrio dos átomos nas moléculas que formam aquela tira. $\mathrm{O}$ momento seguinte incluirá uma atividade em que os estudantes serão solicitados a realizar um pequeno 
experimento: encostando uma tira de borracha nos lábios, eles deverão sentir o efeito térmico decorrente do trabalho que os dedos realizam ao puxá-la rapidamente. A percepção sensorial do aumento da temperatura da borracha assim que ela é submetida a uma tração é um bom expediente para dar partida a um deslocamento da atenção dos estudantes em direção aos movimentos vibratórios que os átomos executam em torno de sua posição de equilíbrio. As duas facetas mencionadas concretizam modos diferentes de exemplificar o conceito de ligação química, exibindo-o ora pela perspectiva da estrutura cristalina, ora pela perspectiva dos fenômenos térmicos. A mesma situação de planejamento permite ver, ainda, que a formação de uma totalidade de PP depende de conseguir que os exemplos particulares selecionados pela performance funcionem em duas direções: da performance para a peça, os exemplos devem comentar e remeter ao sistema de distinções e similaridades que ela traz implicitamente; e no sentido oposto, da peça para a performance, aqueles e outros exemplos devem receber parte de seu significado das mesmas distinções e similaridades que anteriormente começaram a ser colocadas à mostra. Em suma, uma exemplificação bem planejada é responsável pela coesão da estrutura de peça-performance, estando os exemplos no papel de mediadores em uma interação de troca. O sistema de distinções e similaridades que essa interconectividade libera se coloca a serviço da compreensão de determinados aspectos do mundo e contribui para o mérito estético da estrutura de PP.

\section{A projetibilidade de uma performance}

Anteriormente, afirmou-se que para dar forma a uma performance do padrão configurado a partir das relações entre conceitos e normas de uma peça de conhecimento físico abstrata, um mediador precisa planejar e executar um evento de mediação que funcione como amostra daquele padrão. A menção da idéia de amostra aponta para casos mais familiares, tais como o procedimento para aferir o conteúdo de sacas de grãos, ou mesmo as amostras de cor e textura de um mostruário de tintas. Estes casos figuram também como parte do esforço teórico de Goodman em seu projeto de expor as características de funcionamento de símbolos das mais variadas modalidades (cf., Goodman, 1978, [IV, 3] e [VII, 6]). Para os fins desse estudo, eles serão aqui 
considerados para ver até onde podem levar a compreensão sobre as exigências que recaem sobre a mediação no ensino de física.

No caso dos testes de qualidade de grãos, o que se requer do procedimento de amostragem é que ele seja capaz de aumentar as chances de que certos aspectos composicionais de uma amostra tirada em conformidade com ele sejam representativos da composição global de uma saca de grãos: a boa amostra projeta para a compreensão de como tais aspectos se apresentam na composição de outras amostras e da saca como um todo.

Analogamente, as amostras em um mostruário de padrões e estampas dos tecidos de uma alfaiataria devem ser corretamente cortadas, de modo a exibir características que dêem a um observador condições de apreender a configuração global do padrão existente em um rolo de tecido que não está diretamente presente para os sentidos. Quando isto se verifica, tem-se uma amostra projetável, ou seja, uma amostra que oferece suporte para que a compreensão se mova do parcial para o global, por meio de um procedimento de preenchimento ou suplementação.

Apresenta-se nas observações anteriores um requisito completamente geral, estendendo seu alcance para todo item que possa vir a funcionar como amostra, independente do que seja. Elas põem em destaque o fato de que nem toda amostra pode ser experienciada como boa ou justa, distinção esta reservada somente a amostras projetáveis. Transpondo estas considerações para a estética do planejamento de performances no ensino de física, vê-se, portanto, que uma performance esteticamente boa deve possuir projetibilidade. Ser projetável significa que a performance é uma amostra que faz jus aos encaixes que contribuem para a configuração inteligente da peça, de tal maneira a mostrar que a peça existe para que se veja como sua arquitetura se mostra altamente bem ajustada para ordenar certo domínio da experiência, evidenciando aspectos inusitados e relevantes desse domínio; desse modo, uma performance projetável está pré-adaptada para exibir esses encaixes entre peça e mundo físico como a realização de um propósito da prática da física.

Uma tentativa mal sucedida de projetar o estudante da situação educativa singular de que participa às relações que compõem a configuração abstrata da peça colimada indica que a experiência do estudante é impedida de se transformar, o que implica que o processo de preenchimento das lacunas entre a performance e a peça é 
truncado. Em outras palavras, tendo sido negadas as condições necessárias para poder assumir uma posição de apreciador, sua visão não discrimina relações entre aspectos cognitivos, normativos e estéticos que há para enxergar no encaixe entre performance, peça e mundo. Isso pode acontecer em virtude de o mediador deixar de observar uma ou mais condições básicas de projetibilidade, algumas das quais são lembradas na relação a seguir:

1) Partir das experiências e dos usos de linguagem dos virtuais apreciadores, i.é, os estudantes;

2) Fomentar a construção de hábitos de uso de linguagem e de ações que dêem aos estudantes pistas sobre o que devem esperar da performance, e permitam reconhecer circunstâncias em que ocorre uma consumação dessas expectativas - em suma, formar padrões de uso de linguagem que gerem imediaticidade no entendimento das regras de projeção que estão em jogo na compreensão da performance.

3) Observar as relações que sistematizam a estrutura formal da peça a ser exemplificada.

4) Buscar compor um roteiro em que as expectativas expostas ao longo da performance sejam concretizadas com a efetiva instanciação de alguns propósitos da prática científica.

5) Observar os papéis que a linguagem estética pode assumir a serviço de sinalizar caminhos do particular ao geral.

6) Apresentar um nível suficiente de contraste que permita discernir os atributos efetivamente exemplificados de outros que meramente acompanham de forma neutra a composição da amostra, mostrando o que é relevante no contexto em questão.

7) Aquinhoar o estudante com sua parcela intransferível de responsabilidade pela construção de significado para a peça; o intérprete não deve fingir ser possível realizar, somente com sua própria atuação na performance, o preenchimento de todas as lacunas entre esta e a peça, sem a solidariedade dos outros participantes da atividade de compreensão da peça, aos quais a performance se destina. 
Além da observância dessas condições básicas, é necessário ter nitidez a respeito da incidência nas situações educativas de instâncias dotadas de características de simbolização de natureza diferente das da performance: o que uma situação instancia nem sempre funciona como amostra de traços compatíveis com os propósitos específicos dessa situação. O esforço de exemplificação das performances voltado à compreensão das peças de conhecimento pode vir a ter a competição do funcionamento simbólico dessas outras instâncias, quando o exercício de cada uma dessas funções irá tentar prevalecer sobre e fazer submergir o outro. Embora como parte de uma situação educativa possam ser encontrados elementos como:

- a pessoa que encontrei ontem no cinema;

- a palavra que também pode ser encaixada a outros contextos;

- a menção de que o estudo em andamento se liga a uma avaliação na semana seguinte;

- o modo de agir de alguém que pode ser julgado como similar ou contrastante com o de determinado grupo, etc.

a performance deve poder ser considerada pelos participantes, não como uma amostra desses atributos, mas sim de uma peça de conhecimento físico. É preciso colocar em segundo plano qualquer funcionamento simbólico atribuído a características, gestos, ações, falas e objetos da circunstância em andamento por versões que não se encaixam ao mundo de uma performance de um saber; ou seja, símbolos que não estabeleçam ou que destruam relações com os propósitos de compreensão a serem consumados na atividade.

Assim, a fim de operar uma necessária restrição nas possibilidades de leitura da matéria ou mote global das situações educativas, deve haver a construção de consensos sobre a necessidade de realizar esforços compartilhados para um ajuste dinâmico das práticas, padrões de ação e outros símbolos que atuam no ambiente em que a performance se sucede. Um contexto escolar no qual todos os traços do ambiente físico e das formas de relacionamento humano sugerem aos atores a noção de repartição burocrática, ou de cárcere, ou de consumismo, ou de negócio entre empresário e clientes, ou de promessa de um meio de vida, indica que simbolizações estranhas ao esforço de compreensão estão permanentemente ocupando o primeiro plano da atenção. 
Isso gera uma interferência negativa sobre as condições de projetibilidade das performances. Deve-se, portanto, tomar atenção com os tipos de funcionamento simbólico que se estabelecem de uma maneira habitual em um ambiente educacional particular. O que aí acontece pode ser semelhante à presença de ruído que se superpõe a melodia, harmonia e ritmo em uma execução ou gravação musical.

\section{A concretização da performance}

Ao reorientar as ênfases colocadas sobre a concepção de ensino-aprendizagem da física de modo a adquirir consciência do espaço que as experiências estéticas ocupam neste processo, ele passa a ser compreendido como processo de tramar padrões de significado. No território da experiência estética de exemplares do conhecimento da física, não basta que haja somente uma fusão de PP. É necessário o entrelaçamento, a trama de PPP, i.é, de peça, performance e participantes. $\mathrm{O}$ terceiro $\mathrm{P}$ é introduzido para levar em consideração a participação dos indivíduos, com as peculiaridades do relacionamento concreto que vêm a estabelecer com uma atividade educativa, e ainda a influência dos traços singulares encontrados em cada contexto específico. É da formação de totalidades de PPP que se realiza a produção de significado para a experiência da educação em ciências físicas. Uma situação bem sucedida de ensino-aprendizagem de física é, pois, uma situação em que se totaliza uma unidade sintética que integra

Peça — Performance — Usos da linguagem — Intérpretes — Apreciadores.

O significado que se produz em ocasiões que incorporam esta qualidade de sumarização é resultado de uma fusão inseparável de forma, conteúdo, contexto e participação.

A fusão desses elementos de uma atividade comunicativa com produção de um significado total é um traço distintivo da linguagem estética. Ela atua na trama da estrutura de PP com elementos encontrados em um contexto particular, entremeando fios de experiências anteriores e em andamento dos participantes $\left(3^{\circ} \mathrm{P}\right)$ em totalidades de significado que tomam como referências os padrões gerais da peça $\left(1^{\circ} \mathrm{P}\right)$ e os elementos de mediação da performance $\left(2^{\circ} \mathrm{P}\right)$. Por essa razão, a linguagem estética se transforma em um instrumento adequado para as projeções que vão da experiência particular de uma situação de aprendizagem para os conceitos e estruturas gerais da 
visão de mundo da física. É possível afirmar, portanto, que o uso de termos estéticos pode funcionar como um meio de direcionar o processo de construção da compreensão: termos e expressões com conteúdo estético têm aptidão para assumir um papel dinâmico no movimento da performance. O modo como efetivamente desempenham essa função é apontando para a formação de relações cognitivas e normativas que sejam relevantes ou irrelevantes para a disciplina e para sua compreensão pelos estudantes, preparando a expectativa dos participantes de uma experiência educativa para a percepção de propósitos que estão a caminho de serem realizados e sinalizando momentos em que se realizou a projeção para um propósito específico da física enquanto disciplina. Concretizar essa projeção é passar a avistar a experiência de uma totalidade de PPP específica como um evento que expõe a existência de toda uma classe de totalidades de significado que podem vir a ser experienciadas subseqüentemente no âmbito da compreensão dos saberes da física. Isso costuma vir acompanhado por um sentimento de que algo definitivo foi alcançado e que, portanto, merece ser preservado.

Assim, a conseqüência de um uso bem sucedido da linguagem estética por mediadores e demais participantes da concretização de uma performance é a produção de um significado sintético para uma peça de conhecimento físico, dando condições para que esta peça seja compreendida simultânea e solidariamente no plano cognitivo e no plano afetivo. No primeiro deles, irá orientar os estudantes a construir relações que apontem distinções entre o relevante e o irrelevante, o que deve ser incluído e o que deve ser excluído da prática da física. Estas conseqüências cognitivas das formas aqui referidas de emprego da linguagem estética estão organicamente entrelaçadas com sua ação no plano afetivo, em que seus termos e expressões se encontram relacionados com:

1) a preparação da expectativa dos participantes da atividade compartilhada para a percepção de virtuais propósitos dessa atividade, propósitos que muitas vezes não podem ser verbalizados;

2) a marcação de momentos da atividade em que esta atinge um clímax, com o alcance de um resultado cabal e definitivo;

3) a comunicação do sentimento de que o participante esbarrou com aspectos da ordem subjacente ao mundo real — um sentimento de objetividade dos saberes da física. 
Observa-se, desta forma, que o uso de linguagem estética em relações com o conhecimento da física reaviva e liberta conexões deste conhecimento com uma dimensão que, ao mesmo tempo, se interliga com sua dimensão factual e a ultrapassa. Para este contexto, é altamente sugestivo transladar um conceito criado pelo psicólogo Jerome Bruner (1997) a fim de explicar os mecanismos mediante os quais uma grande obra literária adquire sua capacidade de capturar o leitor, o poder de trazê-lo para dentro dela de modo a alistá-lo na construção de significados possíveis da obra e que ao mesmo tempo incorporem a perspectiva desse leitor. Trata-se de uma qualidade do discurso literário a que Bruner se reporta como um poder de subjuntivizar a realidade:

Retiro meu significado de "subjuntivo" do segundo oferecido pelo OED [Oxford English Dictionary]: "Designação de uma disposição (L. modus subjunctivus) cujas formas são empregadas para denotar uma ação ou estado como concebido (e não como um fato) e, portanto, utilizada para expressar um desejo, comando, exortação ou um evento contingente, hipotético ou prospectivo". Estar no modo subjuntivo significa, portanto, estar negociando possibilidades humanas e não certezas estabelecidas (Bruner, p. 28).

O que isto significa no perímetro da concretização de performances de artefatos intelectuais da física é que o uso adequado de linguagem estética na composição da performance permite modelar um discurso sobre fatos em uma disposição não puramente factual. Essa disposição é uma na qual esses fatos recebem parte do seu significado da visão de expectativas que podem ou devem ser mantidas sobre o papel que eles subseqüentemente virão a assumir na consumação de propósitos da física considerada em sua condição de prática humana compartilhada. Em virtude de atuar no terreno de expectativas/consumações, a linguagem estética pode doar subjuntividade à peça de conhecimento físico. Como conseqüência, propicia-se ao estudante um espaço para que ele forme sua compreensão de uma parcela do mundo físico, não apenas porque assimila os fatos que lhe são impostos pelo conhecimento estabelecido, mas porque é posto em contato com um modo de apresentação desses fatos que o convoca para elaborar um sentimento sobre eles. Fatos passam de simples objetos de aceitação por exigências racionais a focos de um sentimento de concordância: os fatos não são apenas certos; mais do que isso, passam a poder ser sentidos e imaginados como certos pelos participantes da performance. 
Como exemplo de uso da linguagem estética para subjuntivizar uma descrição factual da física, considere-se a relação entre as variáveis físicas de pressão e profundidade em um fluido. Em uma de suas aplicações específicas, esta relação poderia ser enunciada simplesmente na forma da afirmativa factual "a pressão da água aumenta com a profundidade de acordo com a regra tal". O processo de subjuntivização desta afirmativa factual tem início com sua reconfiguração em uma forma exemplificativa intermediária, tal como

“a espessura da parede de uma barragem aumenta com o aumento da pressão da água".

O passo final é então realizado com a apresentação de uma amostra concreta daquela relação - por exemplo, uma fotografia da parede de uma barragem que exemplifique o seu formato - que sirva como ponto de apoio para transformá-la em um modo como

"Percebam neste exemplo como é bonita a maneira como o aumento da espessura da parede foi projetado em resposta ao aumento da pressão da água!".

Nesta situação, o ato de fala "Percebam como é bonito ... o modo como foi projetado para ..." gera uma expectativa sobre um fato subseqüente; ao mesmo tempo, a consumação da expectativa é realizada ao ser apontado o encaixe entre a relação factual entre pressão e profundidade e a apresentação do formato da parede de uma represa. $\mathrm{O}$ resultado dessa transformação será a geração de perspectivas pessoais sobre a relação factual focalizada.

Em suma, porque a linguagem estética promove a subjuntivização, o seu uso em performances de peças de conhecimento físico contribui para organizar um espaço de realização compartilhada de significado, influenciada pelas expectativas que são comunicadas no processo. No interior deste espaço, o apreciador é convidado a inserir suas próprias experiências de significados estéticos, e pode então atender a uma convocação para refazer suas experiências enquanto compartilha a tarefa de produção de significado para a peça. $O$ interesse que o conceito de subjuntivização possui no terreno das relações que um estudante pode vir a manter com o conhecimento científico é, portanto, o de chamar atenção para o fato de que o uso da linguagem estética tem condições de assumir o papel de um poderoso instrumento no alcance de encaixes entre expectativas, valores e interesses da pessoa engajada na compreensão de significados da 
física e os fatos dessa disciplina científica. Esse conceito escancara um preceito a ser seguido na mediação nas ciências físicas: a compreensão a ser construída pelo estudante de que certos fatos, normas e condutas devem ser incluídos na situação educativa, enquanto outros devem dela ser excluídos, deve repousar sobre a percepção do valor desses elementos, em uma experiência compartilhada pelo próprio estudante.

\section{Estrutura geral da concretização da performance}

Se a performance é bem sucedida em preparação, execução e apreciação, todos os indivíduos participantes são integrados a uma experiência total que se carrega de um tom de consumação. Aos olhos de todos, o processo terá conduzido do sentimento antecipado de um propósito para a sua realização final. Tem-se, então, uma experiência estética, cujo significado está relacionado ao sentimento de que, desde o início, as relações construídas apontavam para um fim, como se estivessem predestinadas ao cumprimento de um propósito. Seu significado se mostra na construção de um ajuste entre meios particulares e finalidades gerais. Um ajuste que, uma vez apreendido por intermédio do engajamento em uma performance, se exibe como iluminação de uma visão a um só tempo inesperada e satisfatória. Sentimento de consumação, visão revelatória e ajuste de experiências particulares a fins gerais são os atributos da experiência estética que a levam a adquirir um caráter imediato análogo ao da percepção de uma qualidade factual; ter uma experiência da adequação de uma peça de conhecimento físico, por exemplo, é tão concreto quanto ver cores e formas de objetos.

A produção e a apreciação de performances são, portanto, gestos de criatividade, movimentos que dão origem a novas maneiras de dar sentido à experiência. Estes gestos buscam realizar uma fusão de elementos que prepara e antecipa na consciência um desaguar da experiência em curso em outras que estão por vir. Isso confere ao movimento da experiência estética de um participante de atividades de compreensão de artefatos intelectuais um ritmo de ciclos que se movem como trens de onda: do entrelaçamento de partes de experiências prévias para um apogeu de transformação de sentido, faz-se um avanço para uma consumação e entra-se em um novo ciclo.

Esta descrição do mecanismo da experiência estética não é antagônica à aprendizagem de conceitos físicos. Ao contrário, imagens estéticas e conceitos da física 
se constituem por mecanismos análogos. As relações em uma performance estão para a apreciação de peças assim como relações de experiências sensoriais estão para a formação de conceitos:

Einstein deu início à sua introspecção de 1946 [Notas autobiográficas] formulando a pergunta, "O que, precisamente, é o 'processo de pensar' [thinking]?” (...) Nossas primeiras impressões de um mundo exterior são “impressões dos sentidos" das quais “imagens-de-memória emergem”. Certas imagens de memória formam séries. Para Einstein, isto ainda não constitui pensamento. Ele começa quando uma das imagens de memória ocorre um número muito grande de vezes em diversas séries diferentes. A imagem serve como um "elemento de ordenação" para as diferentes séries, um elemento que poderia também relacionar séries até ali desconectadas. Einstein se referiu a este elemento doador de ordem como um “conceito". (Miller, p. 370)

Do conjunto dos argumentos desenvolvidos, que visão emerge da direção seguida pelo processo de formação da compreensão do mundo físico em práticas educativas guiadas por performances de peças de conhecimento?

Um dos principais aspectos é a interação fecunda que se estabelece entre subjuntividade e aprofundamento da compreensão. Caso seja competentemente conduzida na concretização dos eventos de mediação do conhecimento físico, esta interação pode resultar na reaproximação entre as facetas de cognição e afetividade que são as fontes desse conhecimento. De imediato, nota-se que o processo de formação e extensão da compreensão não é linear, mas possui uma estrutura modulada por ciclos que internalizam o movimento da experiência dos participantes da performance. Em situações nas quais essa experiência percorre um roteiro completo de desdobramento, observam-se picos relacionados com experiências de antecipação e de realização de propósitos da disciplina e que têm como conseqüência a formação de totalidades de PPP. A partir daí, o processo aponta para a tendência a um número potencialmente ilimitado de iterações, a serem dirigidas pelo sujeito que passou a participar do modo de descrição do mundo proposto por determinada peça de conhecimento físico.

O resultado que se busca é o de que a performance auxilie pessoas que participam de um esforço compartilhado de compreensão a intercalar entre elas e o mundo uma estrutura de interpretação. Essa estrutura é um filtro que opera de modo a 
realçar alguns aspectos do mundo que se encaixam ao seu padrão geral e a excluir outros. Se inicialmente aqueles participantes passam pela experiência de uma distância, de um estranhamento entre a estrutura da peça e o mundo familiar, o processo deverá ter seqüência com a progressiva redução da distância, até que ela seja praticamente zerada, até que se sinta que a estrutura da peça e as aparições do mundo se encaixam com perfeição. Atingido esse estágio, a percepção do mundo sob a direção da estrutura da peça terá se tornado imediata e satisfatória. Se sintetizado em um diagrama heurístico, o desenrolar do processo apreciativo de peças de conhecimento físico toma a forma representada pela figura a seguir:

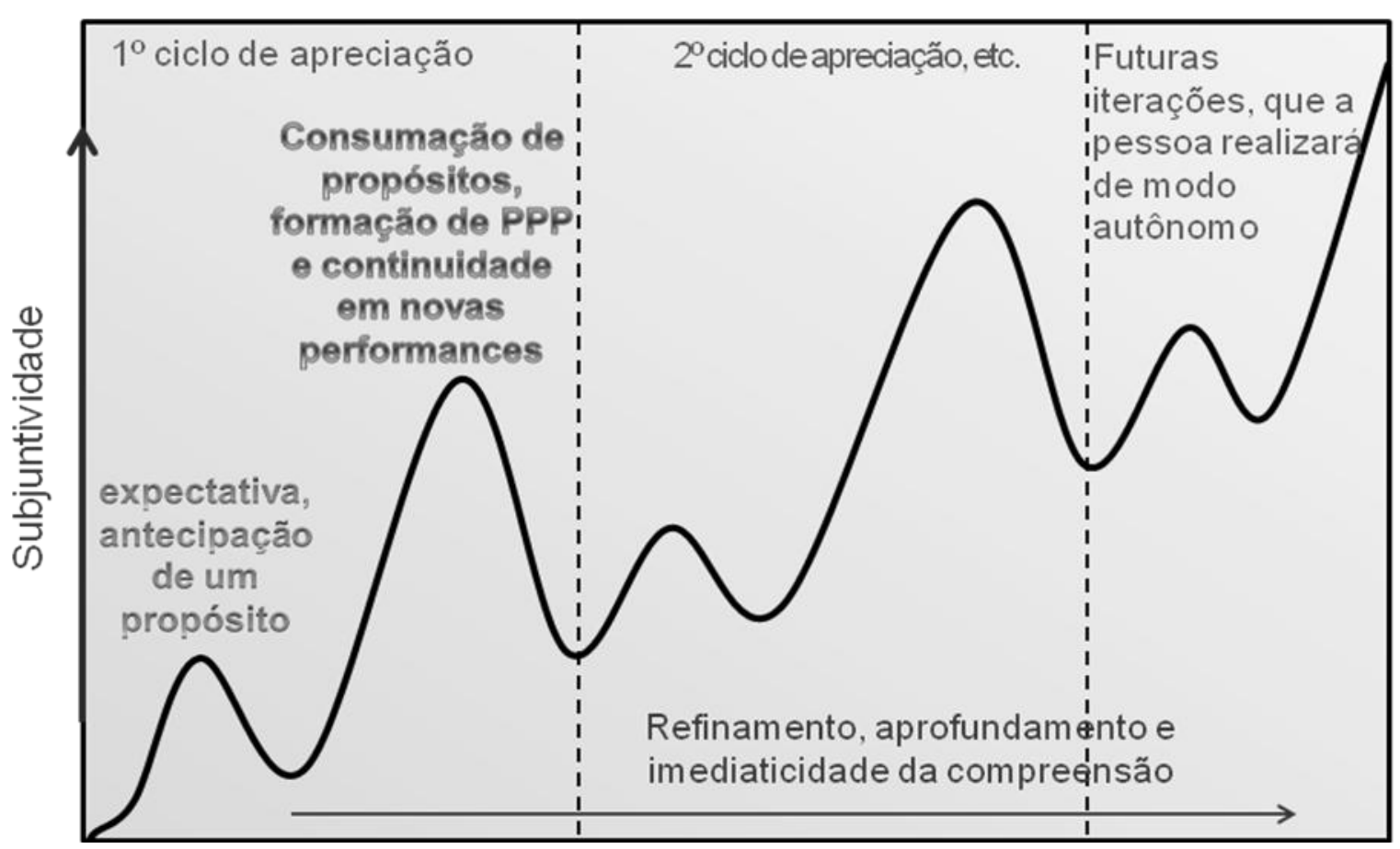

O diagrama mostra que, dentro de cada ciclo de apreciação, a participação da experiência estética na formação da compreensão do conhecimento físico é capturada em dois momentos, nos quais ela atua auxiliando na construção de relações sob orientação da performance (e, mais remotamente, da peça):

$\left.1^{\circ}\right) \mathrm{Na}$ primeira parte da performance (que corresponde aos picos menos pronunciados), leva à geração de expectativas estéticas com respeito a propósitos da atividade compartilhada que podem vir a se cumprir. 
$2^{\circ}$ ) Na segunda parte da performance (que corresponde aos picos mais intensos), tece relações das expectativas iniciais com as conseqüências das relações construídas ao longo da performance; quando as relações construídas durante a situação educativa promovem um curso em que a atividade culmina com a chegada a um fechamento que confirma as expectativas iniciais, a linguagem estética é habitualmente usada para dar notícia de que foi atingido um clímax.

Composta de dois momentos distintos, cada performance tem o papel de ser auxiliar do pensamento e da apreciação para gerar vislumbres, imagens sinópticas nas quais os elementos de um artefato simbólico abstrato apareçam harmoniosamente integrados em uma configuração ilustrativa de um propósito. Atingir esse fim depende de fazer uma seleção apropriada de partes de um conjunto de experiências anteriores dos indivíduos a quem a performance se destina, combinando esses elementos engenhosa e propositalmente para exemplificar, apontar, exibir aspectos parciais de uma peça abstrata e as adequações das relações entre eles. A arte da performance de peças de conhecimento físico consiste em saber como estruturar significados particulares para ir em direção de uma idéia geral. Desse modo, a confecção e a apreciação de performances devem estar concentradas na visão das continuidades existentes entre os aspectos do funcionamento simbólico exibidos por um artefato abstrato da ciência. Quatro desses aspectos se sobressaem. Eles serão aqui denominados: "o quêe", ou o assunto abrangido pela peça; "com quê", referente aos signos que servem de invólucro da peça e da performance; "como", ou o que seria correspondente aos mecanismos e processos de simbolização mobilizados pela performance; e "para quê", compreendendo os interesses, expectativas e propósitos da peça e de sua concretização. Tem-se, portanto:

1) “O quê": objetos e eventos da situação atual; elementos de experiências anteriores dos participantes.

2) “Com quê": os símbolos verbais e não-verbais, palavras e ações.

3) "Como": os padrões de uso da linguagem e suas conseqüências; as relações construídas; o movimento da experiência (de negativa para positiva; de antecipação para consumação); as expectativas e consumações geradas; as distinções realizadas; as funções referenciais exercidas. 
4) "Para quê": as continuidades e transformações de fatos, normas e valores; as totalidades singulares formadas; as conexões com outras totalidades; a participação e o compartilhamento de significados.

Os encaixes entre estes aspectos devem ser observados no decorrer de um processo específico em que eles vão sendo construídos, e não apenas em uma constelação simbólica final e sistematizada. Quanto maior for a continuidade entre os aspectos apontados, mostrados como parte de uma performance singular, mais bela será a performance e, por extensão, a peça de conhecimento. Ao mesmo tempo, no caminho em que esse ajustamento é colimado, é necessário ter em mente que alguns sentidos experienciais que são avaliados negativamente se considerados de maneira isolada assumem uma participação determinante na conquista de um grau elevado de gratificação quando, combinados a outros elementos, integram-se em experiências totais. Portanto, assimetrias, contrariedades, obstáculos e dissonâncias não estão automaticamente excluídos da experiência estética, podendo ser um dos principais ingredientes responsáveis pela consumação ímpar que ela venha a atingir. O conflito pode assumir uma relevância central na totalidade da experiência, tal como acontece com as assimetrias na composição do Demoiselles d'Avignon de Picasso. "Os rótulos que colocamos em realizações positivas que se seguem a expectativas negativas incluem "uma surpresa agradável” ou "um alívio", algo que pode até trazer uma recompensa maior que uma consumação que vem em seguida a uma antecipação positiva" (Wickman, p. 158).

No processo ao longo do qual encaixes entre "o quê", "com quê", "como" e "para quê" do funcionamento simbólico do exemplar de conhecimento físico vão sendo construídos - em uma cooperação que envolve professor, estudantes, conhecimento e mundo - experiências estéticas se transformam por meio dos encontros entre expectativas de certas relações e as conseqüências dessas mesmas expectativas em termos de consumação e fechamento (Wickman, p. 123). Voltando a dirigir o olhar para o diagrama acima, vê-se que a experiência de fatos científicos e de significados estéticos se transforma quando, e apenas quando, as pessoas que participam de um esforço de compreensão obtêm êxito em transformar expectativas cognitivas em consumações cognitivas. Em ocasiões em que um fato em estudo na aula de ciências é preliminarmente delineado, incorporando relações com termos estéticos, isso gera uma expectativa, ao mesmo tempo estética e cognitiva, de consumação daquele fato. Se, 
posteriormente, a realização antecipada vem a ser consumada com a materialização do fato, observa-se, então, que entre o fato antecipado e o fato realizado foi estabelecida uma diferença. Essa diferença consiste em uma variação - em uma linha que se orienta do antes para o depois da consumação - na qualidade de que o fato se torna portador em termos de experiência pessoal e compartilhada. Este é um fenômeno que costuma dar ensejo a manifestações dos participantes mediante a emissão de juízos de assentimento, em que termos estéticos positivos são usados para estabelecer relações com os fatos consumados em experiência. Portanto, devido à continuidade cognitiva da experiência estética quando esta se apresenta em situações de aprendizagens científicas em curso - atuando eficazmente como demarcadores de fatos, qualidades factuais e razões que são válidos naquele contexto - ocorre que transformações nas experiências do uso de expressões estéticas ao mesmo tempo originam e são originadas por transformações de experiências envolvendo fatos e razões. Em um exercício de análise, uma construção bem sucedida dos encaixes de uma peça de conhecimento da física, realizada por intermédio da experiência de performances dessa mesma peça, segue, portanto, as seguintes etapas:

1. Presencia-se, em uma situação educativa determinada, o andamento da construção de relações entre objetos, eventos, ações e termos estéticos com o fito de avançar em direção à concretização de propósitos a essa altura só vagamente visualizados. Tais relações se situam em um nível primário.

2. Sobre as relações primárias constroem-se outras de segunda ordem, ou secundárias, que são aquelas que os participantes dão-se conta de existir entre as relações de objetos, eventos e ações firmadas na situação educativa e uma expectativa de consumação. Em outros termos: uma carga de expectativa estética/factual é relacionada à experiência de uma constelação de objetos, eventos e ações.

3. Por sua vez, as expectativas assim produzidas estabelecem relações de terceira ordem com outras expectativas comunicadas na atividade corrente ou reavivadas de experiências anteriores de professores e estudantes; também são construídas relações entre uma expectativa e a consumação encontrada ao seguir o curso que ela de início apontava. 
Em complemento à representação dada pelo diagrama anterior da interação entre subjuntividade e formação da compreensão, este movimento ascensional no caminho para a visão estética de adequações do funcionamento simbólico-experiencial de uma peça de conhecimento físico poderia ser sumarizado de acordo com o quadro abaixo:

Transformações nas expectativas e nos significados iniciais
$\Uparrow$
Cotejamento das expectativas iniciais com os resultados das experiências estéticas
transformadas
$\Uparrow$
Experiências estéticas se transformam (de - para +, ou de antecipação para consumação)
$\Uparrow$
Esforços para estabelecer uma consumação
$\Uparrow$
Expectativas e significados iniciais cognitivos/normativos/estéticos
$\Uparrow$

\section{Considerações finais}

A performance de uma peça de conhecimento da física se situa no diálogo, concreto e dinâmico, sob a forma de um acontecimento único, de uma atividade situada. $\mathrm{O}$ seu sucesso depende de uma realização dupla. Primeiramente, a performance é uma tentativa de concretizar meios previamente projetados para aumentar a probabilidade de visão da peça abstrata que ela exemplifica. Por outro lado, como parte integrante do ato de concretização daqueles meios em uma performance única, figura a participação insubstituível do estudante, que é sempre convocado a realizar uma concreção da peça que concilie sua marca pessoal com as características intrínsecas a ela. $\mathrm{O}$ processo de exemplificação da peça deve se efetivar na e por intermédio da atividade mental do estudante. Uma vez efetivado, o diálogo se constitui como performance na medida em que encena um particular exemplo de uma via entre a peça e um estudante, via esta que pode ser refeita de múltiplas maneiras. Se um entendido é informado de que foi realizada uma particular performance de uma peça de conhecimento da física, as três 
leis de Newton, por exemplo, ele pode sem dificuldade escrever o caractere de registro com que a performance concorda. Não poderá, entretanto, determinar os instrumentos e métodos específicos que foram eleitos para intermediar o relacionamento do estudante com a peça. $\mathrm{O}$ caractere de registro que define a identidade da peça é relativamente enxuto se comparado ao conjunto dos elementos que entram em uma performance. Diz Goodman que "(...) um registro não precisa captar toda sutileza e complexidade de uma performance. (...) A função de um registro é especificar as propriedades essenciais que uma performance deve ter para pertencer à obra; as estipulações são apenas de certos aspectos e somente dentro de certos graus" (Goodman, 1976, p. 212). Portanto, na constituição da performance para além de um simples caso da peça, somam-se aos caracteres do registro todo um elenco de orientações e instruções suplementares que transformam o caractere de registro em um roteiro ou plano da performance. A partir deste ponto, é acertado dizer que se abre ao professor, ou ao ator que elabora um recurso didático, um espaço em que ele passa a desempenhar papel ao mesmo tempo comparável ao de um intérprete na música e ao de um criador na literatura, podendo colocar em marcha habilidades, por assim dizer, "artísticas" de construção e reconfiguração de símbolos. Por outro lado, se optar por ficar estritamente limitado ao caractere de registro, sem nenhuma outra referência, terminará dando forma a uma performance mecânica e insípida.

A estatura do "artista" é avaliada na proporção de sua capacidade de propor "modos de ver" novos e penetrantes a outros indivíduos que venham a interagir com sua criação. Em carta a seu irmão Théo, Van Gogh lhe comunica sua definição de arte nos seguintes termos:

"A arte é o homem acrescentado à natureza"; à natureza, à realidade, à verdade, mas com um significado, com uma concepção, com um caráter, que o artista ressalta, e aos quais dá expressão, "resgata", distingue, liberta, ilumina.

Um quadro de Mauve ou de Maris ou de Israels diz mais e fala mais claro que a própria natureza. (Van Gogh, 2007, pp. 38-39)

Conseqüentemente, a metáfora, ao lado da exemplificação, são os mecanismos de simbolização básicos de que o professor de física dispõe para assistir na passagem do estudante ao primeiro nível de relacionamento implícito em elementos de conhecimento científico; ambas são, assim, processos simbólicos altamente adequados para evocar a 
atividade de apreciação estética: quando uma amostra de uma particular idéia científica é bem composta e selecionada, ou quando uma metáfora é fecunda e demonstra sua força de persuasão ao estabelecer um compartilhamento bem ajustado de recursos simbólicos entre os domínios distintos que ela entrelaça, há condições para que se abra ao estudante uma fresta para sua visão estética. A probabilidade de que tal visão se estabeleça se explica porquanto, ao levar em conta a experiência do virtual apreciador com certas formas de decodificação e utilização de símbolos, lingüísticos e de outros tipos, se está favorecendo a sintonia e o aprofundamento da sua atenção e de sua atividade mental sobre as idéias abstratas às quais se pretende fazer alusão.

Não poderia ser mais arguta a colocação de Frank Oppenheimer de que "À frente da experiência na filosofia, na ciência e no sentimento existe, inevitavelmente, a busca por uma linguagem capaz de traduzir a precária novidade de notar e entender em uma retórica precisa em significado e em linguagem figurada" (citado por Cole, p. 31). Seguramente se poderiam incluir nesta lista os processos de intermediação que transcorrem no âmbito da educação, em que mecanismos de caráter metafórico atestam um grande valor para o processo gradual de complexificação do pensamento do educando, tendo em vista que, tanto nas artes como na ciência, os objetos que são alvos de uma atitude investigativa boa parte das vezes se projetam em espaços distanciados das experiências em que o pensamento do senso comum se constitui. Conforme já se disse anteriormente, a metáfora atua na pavimentação de caminhos para que o pensamento se entranhe em campos de experiências alheias àquelas em que o ser humano se pauta para desenvolver respostas ao seu ambiente de origem. Este papel da metáfora é algo amplamente reconhecido e, ao se falar em metáforas e modelos, costuma ser enfatizado por seu caráter provisório e limitado. Há, porém, o aspecto recíproco a este que costuma ser negligenciado e que é o mais importante quando se trata de entender os modos de trabalhar a ligação entre os dois níveis de referência para promover a apreciação estética das idéias científicas no ensino e na aprendizagem da física. Este aspecto é iluminado por Goodman ao argumentar em defesa da indissociabilidade no conhecimento entre aquilo que está dado de antemão e o que é constituído como artefato. Assumindo que o modo como o conhecimento do mundo se constitui se distancia de uma simples assimilação de um dado absoluto, um método permanente de conhecimento de algo novo envolve dizer em que medida ele apresenta símiles e distinções em relação a algo velho. Quando se busca conhecer um domínio 
novo a partir de um ponto de vista configurado por aquilo que se sabe de outro domínio previamente explorado, são postos em marcha dois processos que se movem em sentidos opostos. Por um lado, a busca de paralelos e contrastes entre dois territórios ou coisas funciona como procedimento que tem como resultado o esclarecimento daquilo que era de início obscuro; por outro, a semelhança é resultado de um processo bemsucedido de aplicação da metáfora sobre aquele domínio, tão bem-sucedido que, a partir de certo momento, a metáfora deixará de ser reconhecida como tal, passando a ganhar o estatuto de aplicação literal. Tomando a indissociabilidade entre fato e artefato como princípio, compreende-se o quanto a ação de dizer o que algo é se confunde com a ação de dizer com o quê aquilo se parece (Crease, pp. 106-107). 


\section{Conclusão}

\section{Estética e aprendizagem da ciência: aspectos relacionados a transformação, continuidade e situação das experiências dos estudantes}

Toda prática, até o ponto em que pode funcionar como um sistema fechado, goza de autonomia para fixar alguns objetivos próprios a serem perseguidos. A esses objetivos correspondem normas que se deve conhecer para se pôr em condições de reconhecer expectativas e realizações relevantes para aquela prática. Sendo assim, o professor de uma área da ciência, em qualquer nível, deve trabalhar em conjunto com seus estudantes para construir uma compreensão das normas internas que correspondem à disciplina estudada. A linguagem estética mostra-se singularmente apropriada para esse intento. A transformação estética - de uma antecipação para sua consumação, ou de uma experiência estética negativa discordante para uma experiência positiva de assentimento - permite desenvolver uma postura de atenção a aspectos factuais do objeto de estudo. Termos estéticos costumam fazer parte de situações comunicativas como instrumentos para a aprendizagem de normas que definem o que vem a ser uma consumação de uma atividade, e como meios para aprender a reconhecer expectativas da realização dos propósitos dessa atividade. Sendo assim, "aprendizagem de ciências, entre outras coisas, também significa aprender uma nova classe de maneiras estéticas de discernir" (Wickman, p. 141). É preciso entender, no entanto, que acontece com os termos dessa linguagem o mesmo fenômeno que com outros termos cotidianos transferidos para um contexto científico. Assim como nos casos de palavras como "energia", "trabalho" e "força", elementos da linguagem estética do cotidiano são transladados para situações do âmbito da atividade científica, em que passam a ser usados em novas constelações. Conseqüentemente, seus significados sofrem mudanças. Esse fenômeno é claramente visto em uma situação de aula de zoologia, registrada e analisada por Wickman:

(...) os estudantes aprenderam novas relações com termos estéticos aparentados com belo/feio enquanto comparavam dois espécimes de besouro, que diferiam em virtude de serem mais ou menos adequados para o propósito de estudar morfologia. Ao besouro inadequado, se produziu uma relação em termos 
estéticos negativos, ao passo que juízos estéticos positivos foram usados em relação ao besouro intacto.

O esclarecimento de Wickman segue com uma observação importante:

Aparentemente uma transformação trivial de significado, esse tipo de transformação era, contudo, necessário para participar da atividade de entomologia, em que se fazia referência à estrutura de insetos em termos estéticos. É fácil imaginar a hesitação ou os questionamentos suscitados em qualquer pessoa que não esteja familiarizada com a prática dos entomologistas ao ser requisitada a apanhar um "belo" espécime. Também é fácil ver as sutilezas em que um jogo de linguagem estético como esse pode se desenvolver. Descrever todas as regras de um uso como esse de linguagem estética pareceria inalcançável. Elas teriam de abranger não apenas a transformação do uso de termos estéticos como tais, mas também novas relações cognitivas e normativas com respeito a fatos e razões sobre o que constitui um inseto ser intacto e ser uma boa amostra do ponto de vista do que é apropriado para os propósitos dos entomologistas. Enquanto aprendem como os insetos são estruturados, os estudantes ao mesmo tempo precisam aprender a saber como ver que um inseto está intacto e descobrir que modos de exibi-los são mais frutíferos para estudar morfologia. (...) Não poderia haver definições claras em termos proposicionais, que por si mesmas pudessem substituir o conhecimento aprendido em ação e sintetizado mediante [determinado uso de] termos estéticos. (...) para compreender o significado do que é dito, é necessário não só que façamos relações com palavras que já tenhamos ouvido antes. As palavras, conforme são usadas, também devem ser contínuas com experiências prévias, que incluam a experiência dos propósitos da atividade. (Wickman, p. 125, meus grifos).

A partir daí, conclui-se que, em se tratando de incentivar a aprendizagem das distinções que caracterizam um determinado ramo de atividade científica, exige-se do professor uma atenção especial com a oferta de estímulo para transformações de experiências estéticas anteriores e correntes de seus estudantes. Ter atenção ao traço de transformação que as experiências estéticas exibem significa principalmente três coisas: primeiro, ter ciência da possibilidade de antigas expressões estéticas aparecerem em novas relações, com conseqüências em ação diferentes das que se depreendem do seu 
uso no dia a dia; em segundo lugar, entender que o mesmo objeto ou evento pode assumir conotações estéticas opostas pela simples razão de estar situado em contextos distintos: uma lesma na aula de ciências assume um valor estético diferente de que ela própria quando encontrada dentro de casa; e, finalmente, abraçar a incerteza e a negatividade como atributos legítimos da experiência estética que devem ser manejados a favor da aprendizagem, pois, tal como afirma Wickman,

O que uma experiência estética positiva é faz sentido em relação a possíveis experiências negativas, por meio do que faz e o que não faz progredir em uma tarefa específica. (p. 153) (...) Sem risco algum, quando tudo está dado de antemão, não poderia haver nenhuma realização. (p. 154).

Enxerga-se aqui a relevância que tensões e contrastes estéticos podem vir a ter para a aprendizagem. Não se pode ter certeza de que todos os encontros serão positivos sempre, e é justamente a consciência da possibilidade de ocorrer encontros que dão origem a experiências negativas a base para se tornar capaz de discernir e assimilar o positivo. Ao lado disso, a questão da inevitável incidência de experiências estéticas negativas nas aulas de ciências introduz preceitos a que a prática docente precisa estar atenta. Em primeiro lugar, o professor de ciências terá de conquistar uma compreensão sólida a respeito das maneiras em que transformação e continuidade - como aspectos complementares da experiência - repercutem na dinâmica do seu trabalho em conjunto com os estudantes. Informada por essa compreensão, a conduta do professor ganha os contornos de um saber-fazer artístico: ele recorrerá ao seu conhecimento da matériaprima de experiências prévias de seu grupo de alunos e lançará mão de uma habilidade para conduzir o processo em que os alunos reconfiguram os elementos daquelas experiências em novos arranjos que levam em conta as normas e propósitos de uma disciplina científica. Se for bem sucedido nesse processo de aproximação, ele terá observado a transformação da experiência dos alunos em uma totalidade que coaduna aspectos normativos, cognitivos e estéticos e que culmina em um fechamento que o estudante reconhece como sendo o cumprimento de algumas expectativas positivas e a transformação de outras negativas. Conforme nota Wickman em suas observações de práticas reais em aulas de ciências, "um papel importante dos professores era aquele de construir relações de antecipação, relações que com freqüência necessitavam ser transformadas pelos estudantes em experiências estéticas de consumação para fazerem pleno sentido" (p. 127). 
A própria ciência ganha a aparência de um simples amontoado aleatório de fatos quando atividade científica e experiência estética deixam de ser apresentadas em sua condição de profundo imbricamento. A razão disso é que, entre as habilidades básicas que um praticante da ciência e da educação em ciências deve dominar está a de selecionar modos de ver e de proceder, além de saber fazer distinções entre objetos e eventos relevantes e irrelevantes para sua atividade, a fim de guiá-la na direção dos propósitos da prática em que ela se inscreve. Em outras palavras, isto significa ter realizado uma aprendizagem dos valores da ciência. "Os professores usavam juízos estéticos para fazer os estudantes notar relações cientificamente relevantes" (Wickman, p. 99). Em todas as funções mencionadas anteriormente, a experiência estética está diretamente implicada.

Tudo o que foi dito até aqui a respeito do papel constitutivo da estética nas interações envolvidas no ensino e na aprendizagem das ciências se soma para compor um esboço da atuação do professor de acordo com certas linhas gerais. Em primeiro lugar, o professor deverá ter a oportunidade, a iniciativa e o esforço de colecionar encontros com peças de conhecimento do seu campo de estudo em que tenha sido capaz de discriminar, pessoalmente, tipos variados de adequação de grau elevado. Cada professor deve entesourar seu próprio escrínio de gemas delicadas. Na seqüência, ele ou ela devem procurar orientar suas ações para a construção de situações em que os participantes percebam: i. a existência de propósitos determinados que vão se delineando aos poucos; ii. a adequação dos conteúdos de suas próprias experiências anteriores como material para o estabelecimento de novas relações que impelem sua atividade na direção daqueles propósitos. Assim, o metieu do professor de física é o de saber como preparar performances de peças deste campo do saber que se concretizem em situações de encontro entre ele próprio, seus estudantes e o mundo dotadas de um potencial elevado para conduzir todos os participantes a ver uma experiência antecipatória - de conteúdos cognitivo, normativo e estético entrelaçados - se transformando aos poucos em uma experiência de consumação. No âmbito da formação científica de um indivíduo, terá sido em vão selecionar conhecimento que seja rigorosamente verdadeiro se este indivíduo não se puder projetar, executar e recriar na apreciação performances autênticas, ou seja, adequadas tanto no plano simbólico quanto no plano da experiência. 
Uma das modalidades mais fundamentais de interação entre estética e ciência, a exercer marcante influência sobre esta última, é a que se observa no uso de linguagem estética para fins de aduzir razões para modos de proceder: "tais situações não são muito diferentes de usar palavras apropriadamente ao provar um traje no alfaiate, para usar o exemplo de Wittgenstein" (Wickman, p. 151). A partir dessa conexão entre emissão de juízos estéticos e razões que fundamentam a conduta científica vê-se o quanto a estética se acha intimamente relacionada à própria lógica do fazer científico. Falhar no entendimento do modo como juízos estéticos podem funcionar como razões acarreta lacunas no entendimento da lógica do processo científico, e no fim das contas, o impedimento de participar de atividades relacionadas com a ciência. A participação nessas atividades tem, portanto, como condição indispensável o desenvolvimento da capacidade de uso competente da linguagem estética no âmbito de um ramo particular da ciência.

Por todas essas razões, observa-se que, despida de experiências estéticas, o movimento tanto da ciência como de sua aprendizagem se estanca. As experiências estéticas não são somente uma questão relacionada com aquilo a que costumamos nos referir como sentimento ou motivação. O uso de um termo estético sintetiza múltiplos aspectos: uma palavra com conotações relacionadas a belo e feio, assentimento e desaprovação, é um nó, um ponto de cruzamento em que conexões se estabelecem entre normas, fatos, valores e vida em geral. Em vista da atuação sistemática das experiências estéticas como ingrediente intrínseco à aprendizagem da ciência, torna-se sem sentido acalentar um objetivo de fazer a educação em ciências mais estética. As duas alternativas em que poderia se materializar uma educação em ciências livre da influência da estética a tornariam comparável a formas de tortura moral. Uma educação em ciências em que a estética houvesse sido extirpada teria a qualidade de um mero fluxo, na expressão de Dewey, ou seja, um perambular ao léu, sem rota definida e no decorrer do qual nada poderia ser discernido pelo estudante; ou, então, no outro extremo, assumiria a feição de um empreendimento esgotado e morto, sem possibilidade de ofertar novas visões de valor, em que tudo já teria sido percebido e explorado. Em ambos os casos, no vazio ou no abarrotamento, não poderia haver movimento das experiências dos estudantes para um fechamento consumatório. A atividade, e com ela o processo de aprendizagem, estariam assim paralisados. 


\section{Referências bibliográficas}

ANDERSON, P. W. Some Ideas on the Aesthetics of Science. In ANDERSON, P. W. A Career in Theoretical Physics, World Scientific Series in $20^{\text {th }}$ Century Physics, Vol. 7, World Scientific, 1994, pp. 569-583.

BRONOWSKI, J. O Olho Visionário: Ensaios sobre Arte, Literatura e Ciência. Brasília: Editora Universidade de Brasília, 1998.

BRUNER, J. Realidade Mental, Mundos Possíveis, Porto Alegre: Artes Médicas, 1997.

CHANDRASEKHAR, S. Truth and Beauty: Aesthetics and Motivations in Science, Chicago: The University of Chicago Press, 1987.

COLE, K. C. Primeiro Você Constrói uma Nuvem, Rio de Janeiro: Editora Record, 2007.

CREASE, Robert. Os Dez Mais Belos Experimentos Científicos, São Paulo: Jorge Zahar Editora, 2006.

DEWEY, J. Art as Experience, New York: Perigee, 2005.

DUARTE JÚNIOR, J.-F. Fundamentos Estéticos da Educação, Campinas: Papirus, $2^{\text {a }}$ ed., 1988.

DUFRENNE, M. Estética e Filosofia, São Paulo: Perspectiva, 2004.

FARMELO, G. (Ed.) It Must Be Beautiful: Great Equations of Modern Science, London: Granta Books, 2003.

FISCHER, E. P. Beauty and the Beast: the Aesthetic Moment in Science, New York: Plenum, 1999.

FOUREZ, G. A Construção das Ciências: Introdução à Filosofia e à Ética das Ciências, São Paulo: Editora da Universidade Estadual Paulista, 1995.

GAGNEBIN, J. M. História e Narração em Walter Benjamin, São Paulo: Perspectiva, 2007.

GIROD, M. "A Conceptual Overview of the Role of Beauty and Aesthetics in Science and Science Education”, Studies in Science Education; 2007; 43, pp. 38-61.

GOLDMAN, A. H. "Aesthetic Qualities and Aesthetic Value", Journal of Philosophy, 1990; 87, pp. 23-37.

GOODMAN, N. Languages of Art, Indianapolis: Hackett Publishing Co., $2^{\text {nd }}$ ed., 1976. 
Ways of Worldmaking, Indianapolis: Hackett Publishing Co., 1978.

HOLTON, G. J. The Scientific Imagination: Case Studies, Harvard University Press, 1998.

JARDINE, N. The Scenes of Inquiry: on the Reality of Questions in the Sciences, Oxford: Clarendon Press, 1991.

KING, J. P. The Art of Mathematics, New York: Ballantine Books, 1993.

KIVY, P. (Org.) Estética: Fundamentos e Questões de Filosofia da Arte, São Paulo: Paulus, 2008.

KOSSO, P. "The Omniscienter: beauty and scientific understanding", International Studies in the Philosophy of Science, 16, n 1, 2002, pp. 39-48.

MATOS, O. Discretas Esperanças: Reflexões Filosóficas sobre o Mundo Contemporâneo, São Paulo: Nova Alexandria, 2006.

MCALLISTER, J.W. Beauty and Revolution in Science, Ithaca, NY: Cornell University Press, 1996.

MILLER, A. I. Insights of Genius: Imagery and Creativity in Science and Art, MIT Press, 2000.

NOUVEL, P. A Arte de Amar a Ciência, São Leopoldo: Editora Unisinos, 2001.

OSBORNE, H. A Apreciação da Arte, São Paulo: Editora Cultrix, 1978.

OSTROWER, F. Criatividade e Processos de Criação, Petrópolis: Vozes, 2007.

POLANYI, M. Personal Knowledge: toward a Post-critical Philosophy, Chicago: The University of Chicago Press, 1958.

ROOT-BERNSTEIN, R. S. "Aesthetic Cognition", International Studies in the Philosophy of Science, 16, nº 1, 2002, pp. 61-77.

ROSENFIELD, K. H. Estética, Rio de Janeiro: Jorge Zahar Ed., 2006.

SANITT, N. Science as a Questioning Process, Institute of Physics Publishing, 1996.

SANTAELLA, L. Estética: de Platão a Peirce, São Paulo: Experimento, 2a ed., 1994.

SCHILLER, F. A Educação Estética do Homem, São Paulo: Iluminuras, $4^{\mathrm{a}}$ ed., 2002.

SILVA, F. L. Conhecimento e razão instrumental. Revista de Psicologia da USP, v. 8, n. 01, p. 11-31. São Paulo: EDUSP, 1997.

TAUBER, A.I. (Ed.) The Elusive Synthesis: Aesthetics and Science, Amsterdam: Kluwer, 1996.

VAN GOGH, V. Cartas a Théo, Porto Alegre: L\&PM, 2ª Ed., 2007. 
WEINBERG, S. Sonhos de uma Teoria Final: a Busca das Leis Fundamentais da Natureza, Rio de Janeiro: Rocco, 1996.

WICKMAN, P.-O. Aesthetic Experience in Science Education: Learning and MeaningMaking as Situated Talk and Action, New Jersey: Lawrence Erlbaum Associates, 2006.

WITTGENSTEIN, L. Philosophical Investigations, Oxford: Blackwell, $2^{\text {nd }}$. ed., 1967.

ZANETIC, J. Física Também É Cultura, São Paulo: Faculdade de Educação da USP, 1989. Tese de Doutorado. 